\title{
Monofloral Honeys as a Potential Source of Natural Antioxidants, Minerals and Medicine
}

\author{
Rodica Mărgăoan 1,*(D), Erkan Topal ${ }^{2}\left(\mathbb{D}\right.$, Ralitsa Balkanska ${ }^{3}$, Banu Yücel ${ }^{4}\left(\mathbb{D}\right.$, Titanilla Oravecz ${ }^{5}$, \\ Mihaiela Cornea-Cipcigan ${ }^{6, *(D)}$ and Dan Cristian Vodnar ${ }^{7}$ (D)
}

1 Advanced Horticultural Research Institute of Transylvania, University of Agricultural Sciences and Veterinary Medicine Cluj-Napoca, 400372 Cluj-Napoca, Romania

2 Apiculture Research Center, Aegean Agricultural Research Institute, İzmir 35100, Turkey; topalerkan@tarimorman.gov.tr

3 Department of Special Branches-Bees, Institute of Animal Science, Spirka Pochivka 1, 2232 Kostinbrod, Bulgaria; obi4liv4e@mail.bg

4 Department of Animal Science, Faculty of Agriculture, Ege University, İzmir 35100, Turkey; banu.yucel@ege.edu.tr

5 Marketing Department, Faculty of International Management and Business, Budapest Business School, Diósy Lajos u. 22-24., H-1165 Budapest, Hungary; oravecztitanilla@gmail.com

6 Faculty of Horticulture, University of Agricultural Sciences and Veterinary Medicine Cluj-Napoca, 400372 Cluj-Napoca, Romania

7 Department of Food Science, University of Agricultural Sciences and Veterinary Medicine Cluj-Napoca, 400372 Cluj-Napoca, Romania; dan.vodnar@usamvcluj.ro or vodnar_dan@yahoo.co.uk

* Correspondence: rodica.margaoan@usamvcluj.ro (R.M.); mihaiela.cornea@usamvcluj.ro (M.C.C)

Citation: Mărgăoan, R.; Topal, E.; Balkanska, R.; Yücel, B.; Oravecz, T.; Cornea-Cipcigan, M.; Vodnar, D.C. Monofloral Honeys as a Potential Source of Natural Antioxidants, Minerals and Medicine. Antioxidants 2021, 10, 1023. https://doi.org/ $10.3390 /$ antiox 10071023

Academic Editor: Miguel Vilas-Boas

Received: 28 May 2021

Accepted: 18 June 2021

Published: 25 June 2021

Publisher's Note: MDPI stays neutral with regard to jurisdictional claims in published maps and institutional affiliations.

Copyright: (c) 2021 by the authors. Licensee MDPI, Basel, Switzerland. This article is an open access article distributed under the terms and conditions of the Creative Commons Attribution (CC BY) license (https:// creativecommons.org/licenses/by/ $4.0 /)$.
Abstract: Background: vegetative diversity is based on different climate and geographical origins. In terms of beekeeping, herbal diversity is strongly correlated to the production of a wide variety of honey. Therefore, based on the existing plant diversity in each country, multiple honey varieties are produced with different health characteristics. While beekeeping potential and consumption preferences are reflected in products' variety, this leads to an increase in the region's economy and extensive export. In the last years, monofloral honey has gained interest from consumers and especially in the medicinal field due to the presence of phytochemicals which are directly linked to health benefits, wound healing, antioxidant, anticancer and anti-inflammatory activities. Scope and approach: this review aims to highlight the physicochemical properties, mineral profiles and antioxidant activities of selected monofloral honeys based on their botanical and geographical origin. Moreover, this review focuses on the intercorrelation between monofloral honey's antioxidant compounds and in vitro and in vivo activities, focusing on the apoptosis and cell proliferation inhibition in various cell lines, with a final usage of honey as a potential therapeutic product in the fight towards reducing tumor growth. Key findings and conclusions: multiple studies have demonstrated that monofloral honeys have different physicochemical structures and bioactive compounds. Useful chemical markers to distinguish between monofloral honeys were evidenced, such as: 2-methoxybenzoic acid and trimethoxybenzoic acid are distinctive to Manuka honey while 4-methoxyphenylacetic acid is characteristic to Kanuka honey. Furthermore, resveratrol, epigallocatechin and pinostrobin are markers distinct to Sage honey, whereas carvacrol and thymol are found in Ziziphus honey. Due to their polyphenolic profile, monofloral honeys have significant antioxidant activity, as well as antidiabetic, antimicrobial and anticancer activities. It was demonstrated that Pine honey decreased the MDA and TBARS levels in liver, kidney, heart and brain tissues, whereas Malicia honey reduced the low-density lipoprotein level. Consumption of Clover, Acacia and Gelam honeys reduced the weight and adiposity, as well as trygliceride levels. Furthermore, the antiproliferative effect of chrysin, a natural flavone in Acacia honey, was demonstrated in human (A375) and murine (B16-F1) melanoma cell lines, whereas caffeic acid, a phenolic compound found in Kelulut honey, proves to be significant candidate in the chemoprevention of colon cancer. Based on these features, the use of hiney in the medicinal field (apitherapy), and the widespread usage of natural product consumption, is gaining interest by each year. 
Keywords: monofloral honey; phenolic compounds; antioxidant activity; physicochemical properties; anticancer

\section{Introduction}

Honey bees (Apis mellifera L.) are the main pollinators in the world, providing the highest service in crop pollination. They pollinate $90 \%$ of the globally most important crops [1]. Managed honey bees ensure a billion euros in crop production worldwide each year [2]. In some countries, such as the USA (United States of America), pollination service is the primary source of income for beekeepers, who use it to pollinate almond orchards $[3,4]$. There is clear evidence of recent declines in both wild and domesticated pollinators and parallel declines in plants that depend on them [5]. Pollinator declines can result in the loss of pollination services, which has ecological and economic impacts which can significantly affect wild plant diversity, ecosystem stability, crop production, food security and human well-being [5,6]. In the last decade, high levels of bee losses have been reported all over the world. Many factors contribute to the dramatic bee colony losses every year. The most important ones are as follows: agrochemical exposure; the use of fungicides, herbicides and insecticides, "chemisation" in agriculture; bee diseases, nutritional stress, environmental pollution from toxic metals, nitrogen and light, as well as global climate changes [7-11]. Indeed, very often colony losses are the result of the effect of different and complicated factors.

Apart from pollination, many bee products are obtained from honey bees. Honey is the most highly produced bee product in the world. Additionally, products such as bee pollen, bee bread, royal jelly, apilarnil, queen bee larvae, propolis and the bee itself are consumed as food in many countries [12-15].

Honey is a natural sweetening food item which has been consumed by humans for thousands of years. It consists of many macro and micro components such as carbohydrates, water, enzymes, proteins, vitamins, organic and amino acids, phenolic compounds, pollen particles, essential oils and sterols. The physical and chemical composition of honey varies according to its botanical origin, the region where it is produced and the processes applied. In addition to its high nutritional value, it has been found that honey has antimicrobial, antioxidant, anti-inflammatory, antimutagenic and anticarcinogenic effects [16-20]. The main compounds responsible for the antioxidant activity of honey are flavonoids (chrysin, pinosembrine, quercetin, galangin, kaempferol, hesperetin and myceticine), phenolic acids (caffeic, coumaric, ellagic, ferulic and chlorogenic acids), ascorbic acid, catalase, peroxidase, carotenoids and maillards. Honey's antibacterial effect is due to its high osmolarity, low $\mathrm{pH}$, hydrogen peroxide, glucose oxidase enzyme, honeybees' hypopharyngeal secretions, catalase activity resulting from flower pollen and nectar, propolis and its phenolic derivatives [21].

Considering the distinct physicochemical composition and phenolic compounds found in monofloral honeys, this review aimed to highlight the antioxidant, as well as the in vitro and in vivo, activities, focusing on the apoptosis and cell proliferation inhibition in various cell lines, with a final usage of monofloral honeys as a potential therapeutic product in the fight towards reducing tumor growth.

In this review, firstly, the herbal diversity of monofloral honeys is introduced, followed by their antioxidant activity and potential medicinal properties. Furthermore, their physicochemical properties and mineral composition are investigated.

\section{Methods of Review}

A literature search from 1999 to present in Google Scholar, PubMed and ScienceDirect was conducted to identify and select relevant and significant articles related to the mineral, phenolic compounds and medicinal properties of monofloral honeys. 
Keywords including monofloral, unifloral, honey, minerals, phenolics, flavonoids, in vitro, in vivo, anticancer, cell lines and the names of several countries were applied. Natural honey or honeys with unknown species were excluded as they do not meet the purpose of the present study.

\section{Herbal Diversity of Monofloral Honeys}

Vegetative diversity increases because of country sizes, soil types and climatic diversity. Even though monofloral honeys are produced at a global level, there are cases in which these specific honeys are solely produced for their representative countries.

The honeys available in the market differ in quality due to various factors such as geographical, seasonal and processing conditions, as well as flower source and packaging and storage conditions. While the sensory property of honey represents an important parameter in determining its quality for consumers, the biggest effect is related to the colour and crystallization state [22]. Floral variety allows the production of a wide range of economically important honeys (Table 1).

Table 1. Monofloral honeys taxa based on provenance.

\begin{tabular}{|c|c|c|c|c|}
\hline \multirow{2}{*}{$\begin{array}{c}\text { Geographical } \\
\text { Origin/Provenance }\end{array}$} & \multicolumn{2}{|c|}{ Monofloral Honey Taxa } & \multirow[b]{2}{*}{ Common Name } & \multirow{2}{*}{ Reference } \\
\hline & Family & Specie & & \\
\hline \multirow{27}{*}{ Turkey } & Apiaceae & Pimpinella sp. & Anise & \multirow{27}{*}[22-31]{} \\
\hline & & Centaurea solstitialis L. & Yellow star-thistle & \\
\hline & Asteraceae & Centaurea cyanus L. & $\begin{array}{l}\text { Cornflower or } \\
\text { bachelor's button }\end{array}$ & \\
\hline & & Helianthus annuus L & Common sunflower & \\
\hline & & $\begin{array}{l}\text { Taraxacum farinosum Hausskn. \& } \\
\text { Bornm. Ex Hand.-Mazz. }\end{array}$ & Turkish cirtlık & \\
\hline & Brassicaceae & Brasssica sp. & Canola & \\
\hline & & Calluna vulgaris (L.) Hull & Common heather & \\
\hline & Ericaceae & Rhododendron sp. & Rhododendron & \\
\hline & & Astragalus microcephalus Willd & Milkvetch & \\
\hline & Fabaceae & Robinia pseudoacacia L. & Black locust & \\
\hline & & Trifolium sp. & Clover & \\
\hline & & Vicia cracca L. & $\begin{array}{l}\text { Tufted vetch or blue } \\
\text { vetch }\end{array}$ & \\
\hline & Fagaceae & Castanea sativa Mill. & Chestnut & \\
\hline & & Quercus cerris L. & $\begin{array}{c}\text { Turkey oak or Austrian } \\
\text { oak }\end{array}$ & \\
\hline & & Thymus sp. & Thyme & \\
\hline & I amiaceae & Vitex agnus-castus L. & Vitex or chaste tree & \\
\hline & Lamiaceae & Lavandula stoechas L. & $\begin{array}{l}\text { Spanish lavender or } \\
\text { topped lavender }\end{array}$ & \\
\hline & & Lavandula pedunculata Mill. & French lavender & \\
\hline & & Gossypium barbadense L. & Sea island cotton & \\
\hline & Malvaceae & Gossunium hirsutum I & Upland cotton or & \\
\hline & & Gossypium nirsutum L., & Mexican cotton & \\
\hline & & Tilia tomentosa Moensch & Silver linden & \\
\hline & & Cedrus sp. & Cedar & \\
\hline & Pinaceae & Pinus brutia Ten. & Turkish pine & \\
\hline & Rhamnaceae & Paliurus spina-christi Mill. & Jerusalem thorn & \\
\hline & Rosaceae & Prunus cerasus L. & Sour cherry & \\
\hline & Rutaceae & Citrus sp. & Citrus & \\
\hline
\end{tabular}


Table 1. Cont.

\begin{tabular}{|c|c|c|c|c|}
\hline \multirow{2}{*}{$\begin{array}{c}\text { Geographical } \\
\text { Origin/Provenance }\end{array}$} & \multicolumn{2}{|c|}{ Monofloral Honey Taxa } & \multirow[b]{2}{*}{ Common Name } & \multirow{2}{*}{ Reference } \\
\hline & Family & Specie & & \\
\hline \multirow{10}{*}{ Bulgaria } & Apiaceae & $\begin{array}{l}\text { Coriandrum sativum L., Daucus } \\
\text { sp. }\end{array}$ & & \multirow{10}{*}{ [32-35] } \\
\hline & & Carduus nutans L. & $\begin{array}{l}\text { Musk thistle or } \\
\text { nodding thistle }\end{array}$ & \\
\hline & Asteraceae & $\begin{array}{l}\text { Centaurea cyanus L. } \\
\text { Helianthus annuus L, }\end{array}$ & & \\
\hline & Brassicaceae & $\begin{array}{c}\text { Onopordum acanthium L. } \\
\text { B. napus }\end{array}$ & Cotton thistle & \\
\hline & Fabaceae & $\begin{array}{c}\text { R. pseudoacacia, Styphnolobium } \\
\text { japonicum (L.) Schott } \\
\text { Vicia sp. }\end{array}$ & Japanese pagoda tree & \\
\hline & Honeydew honey & Forest honey & & \\
\hline & Polygonaceae & Fagopyrum esculentum Moench & Common buckwheat & \\
\hline & Rosaceae & Prunus sp. & & \\
\hline & Salicaceae & Salix sp. & & \\
\hline & $\begin{array}{l}\text { Saxifragaceae } \\
\text { Tiliaceae }\end{array}$ & $\begin{array}{c}\text { Saxifraga adscendens L. } \\
\text { T. cordata }\end{array}$ & Wedgeleaf saxifrage & \\
\hline \multirow{13}{*}{ Romania } & Asteraceae & $\begin{array}{c}\text { H. annuus, } \\
\text { Taraxacum officinale (L.) Weber ex } \\
\text { F.H.Wigg. }\end{array}$ & Common dandelion & \multirow{13}{*}{ [36] } \\
\hline & Betulaceae & Corylus avellana $\mathrm{L}$ & Common hazel & \\
\hline & Brassicaceae & Brassica napus L. & Canola & \\
\hline & Cornaceae & Cornus mas L. & $\begin{array}{l}\text { European cornel or } \\
\text { Cornelian cherry }\end{array}$ & \\
\hline & $\begin{array}{l}\text { Fabaceae } \\
\text { Fagaceae }\end{array}$ & $\begin{array}{l}\text { R. pseudoacacia } \\
\text { C. sativa }\end{array}$ & & \\
\hline & Lamiaceae & Thymus serpyllum L. & $\begin{array}{l}\text { Breckland thyme or } \\
\text { wild thyme }\end{array}$ & \\
\hline & & $\begin{array}{c}\text { Rubus idaeus L. } \\
\text { Malus domestica Borkh. }\end{array}$ & European red raspberry & \\
\hline & Rosaceae & Malus floribunda Siebold ex Van & Japanese crabapple or & \\
\hline & & Houtte & purple chokeberry & \\
\hline & & Prunus padus L. & Bird cherry & \\
\hline & Salicaceae & Salix caprea $\mathrm{L}$. & Goat willow & \\
\hline & & Tilia platyphyllos Scop. & Large-leaved linden & \\
\hline & 11liaceae & Tilia cordata Mill. & $\begin{array}{l}\text { Small-leaved lime or } \\
\text { little-leaf linden }\end{array}$ & \\
\hline \multirow{5}{*}{ Ukraine } & Asteraceae & H. annuus & & \multirow{5}{*}[37,38]{} \\
\hline & Brassicaceae & B.napus & & \\
\hline & Fabaceae & R. pseudoacacia & & \\
\hline & Polygonaceae & Fagopyrum esculentum Moench. & & \\
\hline & Tiliaceae & Tilia platyphyllos Scop. & $\begin{array}{l}\text { Large-leaved lime or } \\
\text { large-leaved linden }\end{array}$ & \\
\hline \multirow{6}{*}{ Italy } & Apiaceae & Coriandrum sativum L. & $\begin{array}{l}\text { Chinese parsley or } \\
\text { cilantro }\end{array}$ & \multirow{6}{*}{ [39-43] } \\
\hline & Asteraceae & $\begin{array}{c}\text { Dittrichia viscosa (L.) Greuter } \\
\text { H.annuus }\end{array}$ & False yellowhead & \\
\hline & & $\begin{array}{l}\text { Erica arborea } \mathrm{L} . \\
\text { Erica scoparia } \mathrm{L} .\end{array}$ & Tree heather & \\
\hline & Ericaceae & Arbutus unedo L. & $\begin{array}{c}\text { Arbutus or strawberry } \\
\text { tree }\end{array}$ & \\
\hline & & $\begin{array}{l}\text { Rhododendron ferrugineum } \mathrm{L} \text {. } \\
\text { Trifolium pratense } \mathrm{L} .\end{array}$ & $\begin{array}{l}\text { Snow-rose or } \\
\text { rusty-leaved alpenrose } \\
\text { Red clover }\end{array}$ & \\
\hline & Fabaceae & Hedysarum coronarium L. & $\begin{array}{l}\text { French honeysuckle or } \\
\text { sulla }\end{array}$ & \\
\hline
\end{tabular}


Table 1. Cont.

\begin{tabular}{|c|c|c|c|c|}
\hline \multirow{2}{*}{$\begin{array}{c}\text { Geographical } \\
\text { Origin/Provenance }\end{array}$} & \multicolumn{2}{|c|}{ Monofloral Honey Taxa } & \multirow[b]{2}{*}{ Common Name } & \multirow{2}{*}{ Reference } \\
\hline & Family & Specie & & \\
\hline & Fagaceae & $\begin{array}{l}\text { Medicago sativa } \mathrm{L} \text {. } \\
\text { C. sativa }\end{array}$ & Alfalfa & \\
\hline & Honeydew honey & $\begin{array}{c}\text { Abies alba Mill. and/or Picea abies } \\
\text { L. }\end{array}$ & Fir honeydew & \\
\hline & & $\begin{array}{c}\text { Forest Honeydew, Insect: } \\
\text { Metcalfa pruinosa Say }\end{array}$ & Forest honeydew & \\
\hline & Myrtaceae & Eucalyptus camaldulensis Dehnh. & River red gum & \\
\hline & $\begin{array}{l}\text { Rhamnaceae } \\
\text { Rutaceae }\end{array}$ & $\begin{array}{c}\text { Paliurus spina-christi Mill. } \\
\text { Citrus sp. }\end{array}$ & Marruca & \\
\hline & Tiliaceae & $\begin{array}{c}\text { R. pseudoacacia } \mathrm{L} . \\
\text { T. cordata }\end{array}$ & & \\
\hline & Xanthorrhoeaceae & $\begin{array}{c}\text { Asphodelus microcarpus Salzm. et } \\
\text { Viv. }\end{array}$ & Asphodel & \\
\hline \multirow{14}{*}{ Portugal } & Aamaryllidaceae & $\begin{array}{c}\text { Narcissus triandrus L. (Angel's } \\
\text { tears) }\end{array}$ & & \multirow{14}{*}{ [44-46] } \\
\hline & & $\begin{array}{c}\text { Arbutus unedo L., } \\
\text { Frica sn }\end{array}$ & Heather & \\
\hline & Ericaceae & $\begin{array}{c}\text { Erica sp. } \\
\text { Erica umbellata } \mathrm{L} \text {. }\end{array}$ & $\begin{array}{l}\text { Heather } \\
\text { Dwarf Spanish heather }\end{array}$ & \\
\hline & & Rhododendron ponticum $\mathrm{L}$. & $\begin{array}{l}\text { Common } \\
\text { rhododendron }\end{array}$ & \\
\hline & Fabaceae & Cytisus scoparius L. (Link) & $\begin{array}{l}\text { Common broom or } \\
\text { Scotch broom }\end{array}$ & \\
\hline & & Ceratonia siliqua $\mathrm{L}$ & Carob & \\
\hline & Fagaceae & $\begin{array}{l}\text { Fagus sylvatica L. } \\
\text { Thymus sp. (thyme), }\end{array}$ & European beech & \\
\hline & Lamiaceae & Lavandula stoechas L. & $\begin{array}{l}\text { Spanish lavender or } \\
\text { topped lavender }\end{array}$ & \\
\hline & & Lavandula latifolia Medik. & $\begin{array}{l}\text { Portuguese lavender or } \\
\text { broadleaved lavender }\end{array}$ & \\
\hline & Myrtaceae & Eucalyptus globulus Labill. & Southern blue gum & \\
\hline & Rhamnaceae & Frangula azorica Grubov & Azorean buckthorn & \\
\hline & Rosaceae & Prunus lusitanica L. & Portugal laurel & \\
\hline & Rutaceae & Citrus sinensis (L.) Osbeck & Common sweet orange & \\
\hline & Santalaceae & Viscum cruciatum Sieber ex Boiss. & Red-berry mistletoe & \\
\hline \multirow{12}{*}{ Hungary } & Amaryllidaceae & Allium ursinum L. & Wild garlic & \multirow{12}{*}{ [47-49] } \\
\hline & Apocynaceae & Asclepias sp. & Milkweeds & \\
\hline & Apiaceae & Coriandrum sativum L., & & \\
\hline & & H. annuus & & \\
\hline & Asteraceae & Solidago sp. & & \\
\hline & Boraginaceae & Phacelia tanacetifolia Benth & $\begin{array}{l}\text { Lacy phacelia, blue } \\
\text { tansy or purple tansy }\end{array}$ & \\
\hline & Brassicaceae & B. napus & & \\
\hline & Honeydew honey & Forest Honeydew & & \\
\hline & Fabaceae & Vicia sp. & & \\
\hline & Fagaceae & C. sativa & & \\
\hline & Rosaceae & Crataegus sp. & Hawthorn & \\
\hline & Tiliaceae & $\begin{array}{l}\text { R. pseudoacacia } \\
\text { T. cordata }\end{array}$ & & \\
\hline \multirow{6}{*}{ Morocco } & Euphorbiaceae & Euphorbia resinifera O. Berg. & Resin spurge & \multirow{6}{*}{ [50-52] } \\
\hline & Fabaceae & Acacia raddiana Savi & Twisted acacia & \\
\hline & Lamiaceae & Lavandula sp.; Thymus sp. & & \\
\hline & Lamiaceae & Rosmarinus officinalis L. & Rosemary & \\
\hline & Leguminosae & Ceratonia siliqua $\mathrm{L}$. & Carob & \\
\hline & $\begin{array}{l}\text { Myrtaceae } \\
\text { Nitrariaceae }\end{array}$ & $\begin{array}{l}\text { Eucalyptus sp. } \\
\text { Peganum harmala L. }\end{array}$ & Harmal or wild rue & \\
\hline
\end{tabular}


Table 1. Cont.

\begin{tabular}{|c|c|c|c|c|}
\hline \multirow{2}{*}{$\begin{array}{c}\text { Geographical } \\
\text { Origin/Provenance }\end{array}$} & \multicolumn{2}{|c|}{ Monofloral Honey Taxa } & \multirow[b]{2}{*}{ Common Name } & \multirow{2}{*}{ Reference } \\
\hline & Family & Specie & & \\
\hline & Resedaceae & Reseda villosa Coss. & Mignonette & \\
\hline & Rhamnaceae & Zizipus jujuba Mill & Jujube or Chinese date & \\
\hline & Rutaceae & Citrus reticulate Blanco & Mandarin orange & \\
\hline \multirow[t]{2}{*}{ Malaysia } & Fabaceae & $\begin{array}{c}\text { Koompassia excelsa (Becc.) Taub } \\
\text { Acacia sp. }\end{array}$ & Tualang & \multirow[t]{2}{*}[53,54]{} \\
\hline & Myrtacaeae & Melaleuca cajuputi Powell & Gelam & \\
\hline \multirow{10}{*}{ New Zealand } & Asteraceae & Carduus nutans L. & Musk thistle & \multirow{10}{*}{ [55-58] } \\
\hline & Boraginaceae & Echium vulgare L. & $\begin{array}{l}\text { Viper's bugloss or } \\
\text { blueweed }\end{array}$ & \\
\hline & Cunoniaceae & Weinmannia racemosa L.f. & Kāmahi & \\
\hline & Fabaceae & Trifolium sp. & & \\
\hline & Lamiaceae & Thymus vulgaris L. & German thyme & \\
\hline & & Leptospermum scoparium J.R.Forst. & Manuka or New & \\
\hline & Myrtaceae & \& G.Forst. & Zealand teatree & \\
\hline & & Metrosideros umbellate Cav. & Southern rata & \\
\hline & Proteaceae & Knightia excelsa R. Br. & Rewarewa & \\
\hline & Strasburgeriaceae & Ixerba brexioides A.Cunn. & $\begin{array}{c}\text { Tawari and Whakou } \\
\text { when in flower }\end{array}$ & \\
\hline
\end{tabular}

Scientific studies revealed the many properties of compounds isolated from honey. With these features, honeys offer multi-purpose usage possibilities. Monofloral honey is obtained from the nectar of specific source plants and may prove to be more valuable than polyfloral honey. Therefore, the type of honey should be determined before labelling and marketing [59-61].

Various types of honeys are produced in Turkey, mostly Chestnut, Pine, Rhododendron, Milkvetch and Thyme. Bulgarian and Hungarian honeys are more complex, predominantly composed of the following species: Coriander, Thistle, Buckwheat, Willow and Linden, as well as forest honeys. Romanian and Ukrainian monofloral honeys are represented by Canola, Chestnut, Linden, Sunflower and Willow. The honeys from Portugal are rather diverse, being predominant in Buckthorn, Cytisus, Citrus, Eucalyptus, Heather, Lavender, Portugal laurel and Thyme. There are various types of eucalyptus honeys with different chemical constituents based on the geographical origin or production region. Recently, it has been demonstrated that eucalyptus honey has a significant antioxidant activity and it can show antimicrobial effects against many microorganisms [61]. As stated by the National Institute of Standardisation UNI, there are five main Italian monofloral honeys, as follows: Black Locust, Chestnut, Citrus, Eucalyptus and honeydew honey. Aside from these, there are several specific honeys, such as: Asphodel, Eucalyptus, Linden, Clover, Marruca (Paliurus spina-christi), Sulla and Sunflower.

The honeys from Malaysia and Australia are mainly Tualang and Gelam honeys, whereas from New Zealand are Clover, Manuka and Thyme honeys. Manuka honey is collected from Leptospermum scoparium or Leptospermum polygalifolium, of the Myrtaceae family, which can be found throughout New Zealand and eastern Australia [55,56]. Kanuka honey is derived from Kunzea ericoides, as a member of the same botanical family as the manuka tree and, according to Semprini et al. (2019) [57], kanuka-derived honey may offer similar antiviral effects. Tualang honey is rich in phenolic acids, flavonoids and has significant anticancer activity. It is collected from Koompassia excels, which is found in the Malaysian rain forest [53,54].

\section{Phenolic Compounds}

The antioxidant activity altogether with the in vitro activities of honey from various floral sources emphasizes the importance of integrating monofloral honey as a daily 
consumption product. Multiple reports highlight that rich phenolic compounds and the antioxidant capacity of monofloral honeys play a significant role in the expression of a wide range of bioactivities. The most common phenolic compounds in monofloral honeys are shown in Table 2.

Table 2. Phenolic compounds present in monofloral honeys.

\begin{tabular}{|c|c|c|c|c|}
\hline $\begin{array}{l}\text { Phenolic } \\
\text { Compounds }\end{array}$ & Honey Type & $\begin{array}{c}\text { Extraction } \\
\text { Technique/Extraction } \\
\text { Solvent }\end{array}$ & Spectral Analysis & Referencces \\
\hline \multicolumn{5}{|c|}{ Flavonols } \\
\hline Quercetin & $\begin{array}{l}\text { Heather, Lavender; Jelly bush } \\
\text { (Leptospermum polygalifolium), } \\
\text { manuka; Clover, Thyme; Liven } \\
\text { vine; Christmas vine; Chestnut, } \\
\text { Eucalyptus, Citrus, Sulla; } \\
\text { Sesame, Coriander, sunflower, } \\
\text { Savory, Sage }\end{array}$ & $\begin{array}{l}\mathrm{MeOH} ; \\
\mathrm{MeCN}\end{array}$ & $\begin{array}{l}\text { RP-HPLC; } \\
\text { HPLC-PDA; } \\
\text { HPLC-UV; } \\
\text { UHPLC-DAD } \\
\text { MS/MS }\end{array}$ & [62-65] \\
\hline $\begin{array}{l}\text { Quercetin-O- } \\
\text { rhamnoside }\end{array}$ & Liven vine & $\mathrm{MeOH}$ & $\begin{array}{l}\text { HPLC-DAD-ESI- } \\
\text { MS/MS }\end{array}$ & {$[66]$} \\
\hline $\begin{array}{l}\text { Quercetin } \\
\text { 3-orutinoside } \\
\text { (rutin) }\end{array}$ & $\begin{array}{c}\text { Kelulut, Tualang; Chestnut, } \\
\text { Eucalyptus, Citrus, Sulla, } \\
\text { Sesame }\end{array}$ & $\begin{array}{c}\mathrm{MeOH} / \text { water 1:1; } \\
\text { MeCN }\end{array}$ & $\begin{array}{l}\text { LC-ESI-MS/MS; } \\
\text { HPLC-UV }\end{array}$ & {$[64,67,68]$} \\
\hline $\begin{array}{c}\text { Quercetin } \\
3^{\prime}, 3^{\prime} \text {-dimethyl eter }\end{array}$ & Rosemary & MeOH:water (1:1) & CE-ESI-MS & [69] \\
\hline $\begin{array}{l}\text { Quercetin } \\
\text { 7,3'-dimethyl eter } \\
\text { Quercetin }\end{array}$ & Rosemary & MeOH:water (1:1) & CE-ESI-MS & [69] \\
\hline $\begin{array}{l}\text { rhamnosyl-hexosyl- } \\
\text { rhamnoside }\end{array}$ & Sulla, Dill, Lemon, Orange & $\mathrm{MeOH}$ & HPLC-DAD-MS & {$[70]$} \\
\hline Apigenin & $\begin{array}{l}\text { Buckwheat, manuka, tualang, } \\
\text { chaste, strawberry tree; Sesamum } \\
\text { indicum, jujube, longan, Black } \\
\text { locust, sunflower, linden, basil, } \\
\text { goldenrod, sulla, Citrus, Ziziphus } \\
\text { Spina-Christi, Kelulut, Tualang; } \\
\text { Sesamum indicum; Black locust, } \\
\text { sunflower, linden, sulla, thistle, } \\
\text { basil, buckwheat, rapeseed and } \\
\text { goldenrod; Ziziphus Spina-Christi; } \\
\text { ailanthus, savory; Jujube, longan } \\
\text { and chaste }\end{array}$ & $\begin{array}{c}\mathrm{MeOH} ; \mathrm{MeOH} / \text { water } \\
1: 1\end{array}$ & $\begin{array}{c}\text { HPLV-UV; } \\
\text { LC-ESI-MS/MS }\end{array}$ & {$[64,67,71-74]$} \\
\hline Kaempferol & $\begin{array}{l}\text { Buckwheat, manuka, Liven vine; } \\
\text { Christmas vine; Rosemary; } \\
\text { Tualang, manuka, Black locust, } \\
\text { chestnut, savory, sulla, ailanthus, } \\
\text { thymus and orange }\end{array}$ & $\begin{array}{c}\mathrm{MeOH} ; \mathrm{MeOH} \text { :water } \\
(1: 1)\end{array}$ & $\begin{array}{l}\text { HPLC-DAD-ESI- } \\
\text { MS/MS; } \\
\text { CE-ESI-MS; } \\
\text { LC-ESI-MS/MS }\end{array}$ & {$[66,67]$} \\
\hline Kaempferid & Rosemary & MeOH:water (1:1) & CE-ESI-MS & [69] \\
\hline Isorhamnetin & $\begin{array}{l}\text { Liven vine; Christmas vine, } \\
\text { manuka; }\end{array}$ & $\mathrm{MeOH}$ & $\begin{array}{l}\text { HPLC-DAD-ESI- } \\
\text { MS/MS }\end{array}$ & {$[66,75]$} \\
\hline $\begin{array}{c}\text { 8- } \\
\text { methoxykaempferol }\end{array}$ & Liven vine; Christmas vine & $\mathrm{MeOH}$ & $\begin{array}{l}\text { HPLC-DAD-ESI- } \\
\text { MS/MS }\end{array}$ & [66] \\
\hline Galangin & $\begin{array}{l}\text { Buckwheat, manuka, black } \\
\text { locust, chestnut, savory, sulla, } \\
\text { ailanthus, thymus; sage }\end{array}$ & $\begin{array}{c}\mathrm{MeOH} ; \\
40 / 50 / 10(v / v / v) \\
\text { water/TFA/MeCN }\end{array}$ & $\begin{array}{l}\text { HPLV-UV; } \\
\text { UHPLC-DAD } \\
\text { MS/MS }\end{array}$ & {$[65,71,76]$} \\
\hline Genistein & $\begin{array}{l}\text { Acacia, Thymus, Black locust, } \\
\text { chestnut, savory, sulla, ailanthus, } \\
\text { thymus and orange }\end{array}$ & $\begin{array}{c}\mathrm{MeOH} ; \\
40 / 50 / 10(v / v / v) \\
\text { water/TFA/MeCN }\end{array}$ & $\begin{array}{l}\text { HPLC-PDA; } \\
\text { HPLC-UV }\end{array}$ & [75-77] \\
\hline
\end{tabular}


Table 2. Cont.

\begin{tabular}{|c|c|c|c|c|}
\hline $\begin{array}{l}\text { Phenolic } \\
\text { Compounds }\end{array}$ & Honey Type & $\begin{array}{c}\text { Extraction } \\
\text { Technique/Extraction } \\
\text { Solvent }\end{array}$ & Spectral Analysis & Referencces \\
\hline Myricetin & $\begin{array}{l}\text { Rosemary; Chestnut, eucalyptus, } \\
\text { citrus and sulla; Sesamum } \\
\text { indicum, black locust, thistle, } \\
\text { Lavender, orange blossom, } \\
\text { heather; ailanthus, Buckwheat }\end{array}$ & $\begin{array}{c}\text { MeOH:water (1:1); } \\
\text { MeOH; MeCN }\end{array}$ & $\begin{array}{l}\text { CE-ESI-MS; } \\
\text { HPLC-UV }\end{array}$ & {$[64,68,69,73,78]$} \\
\hline Methyl anthranilate & Citrus & $\mathrm{MeOH}$ & GC-MS & [43] \\
\hline \multicolumn{5}{|c|}{ Flavanols } \\
\hline Epicatechin & $\begin{array}{l}\text { Kelulut, Tualang; Chestnut, } \\
\text { eucalyptus, citrus and sulla; } \\
\text { sage; Jujube, longan and chaste; } \\
\text { Tualang, pine } \\
\text { Acacia, Chestnut, eucalyptus, } \\
\text { citrus and sulla, manuka, } \\
\text { Ziziphus Spina-Christi }\end{array}$ & $\mathrm{MeOH} /$ water 1:1 & $\begin{array}{c}\text { LC-ESI-MS/MS; } \\
\text { HPLC-UV }\end{array}$ & {$[67,68,74,75]$} \\
\hline \multicolumn{5}{|c|}{ Flavanonols } \\
\hline Pinobanksin & $\begin{array}{c}\text { Black locust, Rosemary, manuka, } \\
\text { Sulla, Thistle, Citrus, Eucalyptus, } \\
\text { Sage; Dill; Jujube, Longan and } \\
\text { Chaste }\end{array}$ & $\begin{array}{l}\text { MeOH:water (1:1); } \\
\text { MeOH; } \\
\text { MeCN; }\end{array}$ & $\begin{array}{l}\text { CE-ESI-MS; } \\
\text { HPLC-PDA; } \\
\text { UHPLC-UV; } \\
\text { UHPLC-DAD } \\
\text { MS/MS }\end{array}$ & {$[65,69,70,77,80]$} \\
\hline Pinocembrin & $\begin{array}{l}\text { Rosemary, Sage; Dill; Jujube, } \\
\text { Longan And Chaste; Acacia, } \\
\text { Sunflower, Linden, Basil, Citrus, } \\
\text { Buckwheat, Goldenrod, Black } \\
\text { Locust, Sulla, Thistle }\end{array}$ & $\begin{array}{c}\text { MeOH:water (1:1); } \\
\text { MeCN }\end{array}$ & $\begin{array}{l}\text { CE-ESI-MS; } \\
\text { UHPLC-DAD } \\
\text { MS/MS }\end{array}$ & {$[65,69,70,74]$} \\
\hline Pinostrobin & 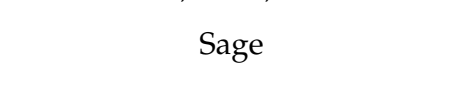 & $\mathrm{MeCN}$ & $\begin{array}{l}\text { UHPLC-DAD } \\
\text { MS/MS }\end{array}$ & {$[65]$} \\
\hline \multicolumn{5}{|c|}{ Flavones } \\
\hline Chrysin & $\begin{array}{l}\text { Rosemary; Kelulut, Tualang; } \\
\text { Buckwheat, Manuka; Sulla, } \\
\text { Thistle, Black locust, Citrus; } \\
\text { Lavender, Eucalyptus, Thyme, } \\
\text { Chestnut; Sage; Sunflower, } \\
\text { Linden, Basil, Buckwheat; } \\
\text { Ziziphus spina-christi }\end{array}$ & $\begin{array}{c}\mathrm{MeOH} / \text { water }(1: 1) ; \\
\mathrm{MeOH} ; \\
\mathrm{MeCN} ; \\
\text { 40/50/10 }(v / v / v) \\
\text { water/TFA/MeCN }\end{array}$ & $\begin{array}{c}\text { CE-ESI-MS; } \\
\text { LC-ESI-MS/MS; } \\
\text { UHPLC-UV; } \\
\text { HPLC-DAD-TOF-MS }\end{array}$ & $\begin{array}{c}{[65,67,69,71,72,76,} \\
80]\end{array}$ \\
\hline Acacetin & Acacia & $\mathrm{MeOH}$ & HPLV-UV & [77] \\
\hline Luteolin & $\begin{array}{l}\text { Black locust, Sulla, Thistle, } \\
\text { Citrus, Manuka, Tualang, } \\
\text { Sunflower; Rhododendron, } \\
\text { Rosemary; Raspberry, Orange, } \\
\text { Cherry Blossom, Dandelion, } \\
\text { Melon, Lavender, Sage, } \\
\text { Rapeseed, Sunflower, Linden, } \\
\text { Basil, Buckwheat, Thyme, Pine, } \\
\text { Sage }\end{array}$ & $\begin{array}{c}\mathrm{MeOH} ; \\
\mathrm{MeOH} / \text { water } \\
(20: 80, v: v)\end{array}$ & $\begin{array}{l}\text { UHPLC-UV; } \\
\text { HPLC-CEAD } \\
\text { HPLC-ESI-MS }\end{array}$ & {$[72,80,81]$} \\
\hline Baicalein & $\begin{array}{l}\text { Lavender, Orange Blossom, } \\
\text { Rosemary, Heather, Eucalyptus, } \\
\text { Chestnut and Thyme }\end{array}$ & $\mathrm{MeCN}$ & HPLC-DAD-TOF-MS & [78] \\
\hline
\end{tabular}


Table 2. Cont.

\begin{tabular}{|c|c|c|c|c|}
\hline $\begin{array}{l}\text { Phenolic } \\
\text { Compounds }\end{array}$ & Honey Type & $\begin{array}{c}\text { Extraction } \\
\text { Technique/Extraction } \\
\text { Solvent }\end{array}$ & Spectral Analysis & Referencces \\
\hline \multicolumn{5}{|c|}{ Flavanones } \\
\hline Naringenin & $\begin{array}{c}\text { Citrus; Lavender, Orange } \\
\text { Blossom, Rosemary, Heather, } \\
\text { Eucalyptus, Chestnut;Thyme; } \\
\text { Sage, Sulla, Thistle, } \\
\text { Rhododendron; Phacelia, } \\
\text { Pumpkin, Raspberry } \\
\text { Lavender, Orange Blossom, } \\
\text { Rosemary, Heather, Eucalyptus, } \\
\text { Chestnut and Thyme; Ziziphus } \\
\text { Spina-Christi } \\
\text { Sunflower }\end{array}$ & $\begin{array}{l}\mathrm{MeOH} ; \\
\mathrm{MeCN}\end{array}$ & $\begin{array}{l}\text { HPLC-ECD; } \\
\text { HPLC-DAD-TOF- } \\
\text { MS; UHPLC-DAD } \\
\text { MS/MS }\end{array}$ & {$[65,78,81,82]$} \\
\hline \multicolumn{5}{|c|}{ Dihydroflavonols } \\
\hline $\begin{array}{l}\text { 5-methoxy } \\
\text { pinobanksin }\end{array}$ & Acacia, Black locust & $\mathrm{MeOH}$ & HPLC-PDA & [77] \\
\hline \multicolumn{5}{|c|}{ Phenolic acids } \\
\hline $\begin{array}{l}P \text {-Hydroxybenzoic } \\
\text { acid }\end{array}$ & $\begin{array}{c}\text { Acacia, Clover, Heather, } \\
\text { Manuka, Buckwheat; Wild } \\
\text { Chrysanthemum, Milk Vetch, } \\
\text { Jujube, Sage; Sulla, Dill; Black } \\
\text { locust, Rapeseed, Lime, } \\
\text { Goldenrod, Heather, Buckwheat; } \\
\text { Cornflower }\end{array}$ & $\begin{array}{l}\mathrm{MeOH} \\
\mathrm{MeCN}\end{array}$ & $\begin{array}{c}\text { HPLV-UV; } \\
\text { HPLC-DAD; } \\
\text { HPLC-ECD-DAD }\end{array}$ & {$[65,71,77,84-86]$} \\
\hline Vanillic acid & $\begin{array}{l}\text { Black locust, Heather, Liven vine; } \\
\text { Christmas vine; Rapeseed, Lime, } \\
\text { Heather, Cornflower, Buckwheat, } \\
\text { Black Locust }\end{array}$ & $\mathrm{MeOH}$ & $\begin{array}{l}\text { HPLC-DAD-ESI- } \\
\text { MS/MS; } \\
\text { HPLC-ECD-DAD }\end{array}$ & {$[66,77,85,86]$} \\
\hline Phenylacetic acid & $\begin{array}{l}\text { Sweet chestnut; Sage; Chestnut, } \\
\text { Eucalyptus, Sulla; Black Locust, } \\
\text { Lime, Lavender, Rapeseed, } \\
\text { Sunflower, Rosemary, Orange, } \\
\text { Lemon }\end{array}$ & $\mathrm{MeOH}$ & GC-MS; HPLC-UV & {$[79,87]$} \\
\hline $\begin{array}{l}\text { L- } \beta \text {-phenyllactic } \\
\text { acid }\end{array}$ & $\begin{array}{l}\text { Chestnut, Eucalyptus, Sulla; } \\
\text { Black Locust, Lime, Lavender, } \\
\text { Rapeseed, Sunflower, Rosemary, } \\
\text { Orange, Lemon }\end{array}$ & $\mathrm{MeOH}$ & HPLC-UV & [87] \\
\hline $\begin{array}{l}\text { Dl- } p \text {-hydroxy- } \\
\text { phenyllactic } \\
\text { acid }\end{array}$ & $\begin{array}{c}\text { Chestnut, Eucalyptus, Sulla; } \\
\text { Black Locust, Lime, Lavender, } \\
\text { Rapeseed, Sunflower, Rosemary, } \\
\text { Orange, Lemon }\end{array}$ & $\mathrm{MeOH}$ & HPLC-UV & [88] \\
\hline Gentisic acid & - & $\mathrm{MeCN}$ & $\begin{array}{l}\text { UHPLC-DAD } \\
\text { MS/MS }\end{array}$ & [65] \\
\hline Rosmarinic acid & $\begin{array}{c}\text { Sage, Rapeseed, Lime, Heather, } \\
\text { Cornflower, Buckwheat and } \\
\text { Black Locust }\end{array}$ & $\begin{array}{l}\mathrm{MeCN} \\
\mathrm{MeOH}\end{array}$ & $\begin{array}{c}\text { UHPLC-DAD } \\
\text { MS/MS; } \\
\text { HPLC-ECD-DAD }\end{array}$ & {$[65,85,86]$} \\
\hline Phenyllactic acid & $\begin{array}{l}\text { Heather, Thistle, Manuka, } \\
\text { Cornflower }\end{array}$ & $\mathrm{MeCN}$ & HPLC-DAD & {$[79]$} \\
\hline Lumichrome & Cornflower & $\mathrm{MeCN}$ & HPLC-DAD & [79] \\
\hline
\end{tabular}


Table 2. Cont.

\begin{tabular}{|c|c|c|c|c|}
\hline $\begin{array}{l}\text { Phenolic } \\
\text { Compounds }\end{array}$ & Honey Type & $\begin{array}{c}\text { Extraction } \\
\text { Technique/Extraction } \\
\text { Solvent }\end{array}$ & Spectral Analysis & Referencces \\
\hline \multicolumn{5}{|c|}{ Hydroxycinnamic acid } \\
\hline Caffeic acid & $\begin{array}{c}\text { Black locust, Liven vine; } \\
\text { Christmas vine, Buckweat, } \\
\text { Manuka, Citrus; Acacia, Milk } \\
\text { vetch, Wild Chrysanthemum, } \\
\text { Jujube flower; Chestnut, } \\
\text { Eucalyptus, Sulla; Coriandrum, } \\
\text { Gelam, Pine, } \\
\text { Rapeseed, Lime, Heather, } \\
\text { Cornflower, Buckwheat And } \\
\text { Black locust }\end{array}$ & $\begin{array}{l}\mathrm{MeOH} / \text { water 1:1; } \\
\mathrm{MeOH} 43 \%: \mathrm{HCOOH} \\
\quad(57 \%, v / v)\end{array}$ & $\begin{array}{l}\text { HPLC-DAD-ESI- } \\
\text { MS/MS; HPLC-ECD; } \\
\text { HPLC-DAD; } \\
\text { HPLC-UV }\end{array}$ & {$[66,68,82,84-86]$} \\
\hline $\begin{array}{c}\text { Caffeic acid } \\
\text { phenethyl ester }\end{array}$ & Kelulut & $\mathrm{MeOH} /$ water 1:1 & LC-ESI-MS/MS & [67] \\
\hline$P$-Coumaric acid & $\begin{array}{l}\text { Liven vine; Christmas vine; } \\
\text { Tualang, kelulut; Citrus; Acacia, } \\
\text { Milk vetch, Wild } \\
\text { chrysanthemum, Jujube flower; } \\
\text { Chestnut, Eucalyptus, Citrus, } \\
\text { Sulla, Mint, Thymus }\end{array}$ & $\begin{array}{c}\mathrm{MeOH} ; \\
\mathrm{MeOH} / \text { water 1:1; } \\
\mathrm{MeOH} \mathrm{43 \% :HCOOH} \\
(57 \%, v / v)\end{array}$ & $\begin{array}{l}\text { HPLC-DAD-ESI- } \\
\text { MS/MS; } \\
\text { HPLC-ECD; } \\
\text { HPLC-DAD; } \\
\text { HPLC-UV }\end{array}$ & {$[66,68,82,84]$} \\
\hline$O$-coumaric acid & $\begin{array}{c}\text { Chestnut, Eucalyptus, Sulla; } \\
\text { Black locust, Lime, Lavender, } \\
\text { Rapeseed, Sunflower, Rosemary, } \\
\text { Orange, Lemon }\end{array}$ & $\mathrm{MeOH}$ & HPLC-UV & [87] \\
\hline$M$-coumaric acid & $\begin{array}{l}\text { Chestnut, Eucalyptus, Sulla; } \\
\text { Black Locust, Lime, Lavender, } \\
\text { Rapeseed, Sunflower, Rosemary, } \\
\text { Orange, Lemon }\end{array}$ & $\mathrm{MeOH}$ & HPLC-UV & [87] \\
\hline Ferulic acid & $\begin{array}{l}\text { Liven vine; Christmas vine; } \\
\text { Citrus; Acacia, Milk vetch, Wild } \\
\text { Chrysanthemum, Jujube flower; } \\
\text { Black locust, Buckweat; } \\
\text { Chestnut, Eucalyptus, } \\
\text { CitrusSulla; } \\
\text { Sesamum indicum }\end{array}$ & $\begin{array}{c}\mathrm{MeOH} ; \mathrm{MeOH} / \text { water } \\
\text { 1:1; } \mathrm{MeCN}\end{array}$ & $\begin{array}{l}\text { HPLC-DAD-ESI- } \\
\text { MS/MS; } \\
\text { LC-ESI-MS/MS; } \\
\text { HPLC-ECD; } \\
\text { HPLC-PDA; } \\
\text { LC-DAD; } \\
\text { HPLC-DAD }\end{array}$ & $\begin{array}{c}{[64,66-} \\
68,77,79,82,85]\end{array}$ \\
\hline Cinnamic acid & $\begin{array}{c}\text { Black locust, Tualang, kelulut; } \\
\text { Rapeseed, Lime, Heather, } \\
\text { Cornflower, Buckwheat, Black } \\
\text { locust }\end{array}$ & $\mathrm{MeOH} /$ water $1: 1$ & $\begin{array}{l}\text { LC-ESI-MS/MS; } \\
\text { HPLC-PDA; } \\
\text { HPLC-ECD-DAD }\end{array}$ & {$[67,85,86]$} \\
\hline Trans-cinnamic acid & $\begin{array}{l}\text { Chestnut, Eucalyptus, Sulla; } \\
\text { Acacia, Lime, Lavender, } \\
\text { Rapeseed, Sunflower, Rosemary, } \\
\text { Orange, Lemon }\end{array}$ & $\mathrm{MeOH}$ & HPLC-UV & [87] \\
\hline $\begin{array}{l}\text { 2-Hydroxycinamic } \\
\text { acid }\end{array}$ & Tualang, Kelulut & $\mathrm{MeOH} /$ water 1:1 & LC-ESI-MS/MS & [67] \\
\hline $\begin{array}{c}3,4- \\
\text { dimethoxycinnamic } \\
\text { acid }\end{array}$ & Black locust & $\mathrm{MeOH}$ & HPLC-PDA & [77] \\
\hline T-cinnamic acid & Black locust & $\mathrm{MeOH}$ & LC-MS; & {$[77,88]$} \\
\hline Isoferulic acid & $\begin{array}{c}\text { Black locust } \\
\text { Rapeseed, Lime, Heather, }\end{array}$ & $\mathrm{MeOH}$ & HPLC-PDA & {$[77]$} \\
\hline Sinapic acid & $\begin{array}{c}\text { Cornflower, Buckwheat and } \\
\text { Black locust }\end{array}$ & $\mathrm{MeOH}$ & HPLC-ECD-DAD & {$[85,86]$} \\
\hline
\end{tabular}


Table 2. Cont.

\begin{tabular}{|c|c|c|c|c|}
\hline $\begin{array}{l}\text { Phenolic } \\
\text { Compounds }\end{array}$ & Honey Type & $\begin{array}{c}\text { Extraction } \\
\text { Technique/Extraction } \\
\text { Solvent }\end{array}$ & Spectral Analysis & Referencces \\
\hline \multicolumn{5}{|c|}{ Hydroxybenzoic acids } \\
\hline Syringic acid & $\begin{array}{l}\text { Linen vine, Kelulut, Tualang; } \\
\text { Kanuka, Acacia, Milk vetch, } \\
\text { Wild Chrysanthemum, Jujube } \\
\text { flower, Sulla, Thistle, Citrus }\end{array}$ & $\begin{array}{c}\text { Metanol; } \\
\text { MeOH/water 1:1; } \\
\text { MeOH/water 1:1; } \\
\text { MeOH 43\%:HCOOH } \\
(57 \%, v / v)\end{array}$ & $\begin{array}{l}\text { HPLC-DAD-ESI- } \\
\text { MS/MS; } \\
\text { LC-ESI-MS/MS; } \\
\text { HPLC-DAD; } \\
\text { UHPLC-UV }\end{array}$ & {$[66,67,80,84,89]$} \\
\hline Gallic acid & $\begin{array}{c}\text { Tualang, kelulut; Ziziphus } \\
\text { Spina-Christi, Acacia, Prosopis } \\
\text { juliflora (mesquite); Acacia, } \\
\text { Chestnut, Savory, Sulla, } \\
\text { Ailanthus, Thymus, Orange, } \\
\text { Cornlfower, Rapeseed, Citrus, } \\
\text { Heather, Eucalyptus }\end{array}$ & $\begin{array}{c}\mathrm{MeOH} / \text { water 1:1; } \\
\mathrm{MeOH} \mathrm{43 \% :HCOOH} \\
(57 \%, v / v) \\
\mathrm{MeCN}\end{array}$ & $\begin{array}{l}\text { LC-ESI-MS/MS; } \\
\text { HPLC-DAD; } \\
\text { HPLC-UV }\end{array}$ & {$[67,76,84]$} \\
\hline Vanillic acid & $\begin{array}{l}\text { Black locust, Sulla, Thistle, citrus, } \\
\text { Prosopis juliflora (mesquite), } \\
\text { Manuka, Ziziphus Spina-Christi; } \\
\text { Lavender, Rosemary, Sulla, } \\
\text { Rapeseed, Lime, Heather, } \\
\text { Cornflower, Buckwheat, Thistle } \\
\text { Rapeseed, Lime, Heather, }\end{array}$ & $\mathrm{MeOH}$ & UHPLC-UV & {$[81,85-87]$} \\
\hline Ellagic acid & $\begin{array}{c}\text { Cornflower, Buckwheat, Black } \\
\text { locust }\end{array}$ & $\mathrm{MeOH}$ & HPLC-ECD-DAD & {$[85,86]$} \\
\hline Benzoic acid & $\begin{array}{l}\text { Black locust, Buckweat, Manuka; } \\
\text { Chestnut, Eucalyptus, Sulla; } \\
\text { Acacia, Lime, Lavender, } \\
\text { Rapeseed, Lavender, Sunflower, } \\
\text { Rosemary, Orange, Lemon }\end{array}$ & $\mathrm{MeOH}$ & $\begin{array}{l}\text { HPLV-UV; } \\
\text { HPLC-PDA }\end{array}$ & {$[68,77,87]$} \\
\hline $\begin{array}{l}\text { P-hydroxybenzoic } \\
\text { acid }\end{array}$ & $\begin{array}{c}\text { Acacia, Buckwheat, Cornflower, } \\
\text { Milk Vetch, Dill, Citrus, wild } \\
\text { chrysanthemum, Jujube Flower; } \\
\text { Sage, Sulla }\end{array}$ & $\begin{array}{c}\mathrm{MeOH} / \text { water } 1: 1 ; \\
\mathrm{MeOH} 43 \%: \mathrm{HCOOH} \\
(57 \%, v / v) \\
\mathrm{MeCN}\end{array}$ & $\begin{array}{l}\text { HPLC-DAD; } \\
\text { UHPLC-DAD } \\
\text { MS/MS }\end{array}$ & {$[65,70,84]$} \\
\hline $\begin{array}{l}\text { 3-Hydroxybenzoic } \\
\text { acid }\end{array}$ & $\begin{array}{l}\text { Buckwheat; Chestnut, } \\
\text { Eucalyptus, Sulla; Acacia, Lime, } \\
\text { Lavender, Rapeseed, Sunflower, } \\
\text { Rosemary, Orange, Lemon } \\
\text { Kelulut, Paliurus spina-christi }\end{array}$ & $\mathrm{MeOH}$ & LC-DAD & {$[79,87]$} \\
\hline $\begin{array}{l}\text { 4-Hydroxybenzoic } \\
\text { acid }\end{array}$ & $\begin{array}{c}\text { Mill.; Chestnut, Eucalyptus, } \\
\text { Sulla; Acacia, Lime, Lavender, } \\
\text { Rapeseed, Sunflower, Rosemary, } \\
\text { Orange, Lemon }\end{array}$ & $\begin{array}{l}\text { MeOH/water 1:1; } \\
\text { MeOH }\end{array}$ & $\begin{array}{l}\text { LC-ESI-MS/MS; } \\
\text { GC-MS }\end{array}$ & {$[67,79,87]$} \\
\hline $\begin{array}{l}\text { 4-methoxybenzoic } \\
\text { acid }\end{array}$ & $\begin{array}{l}\text { Paliurus spina-christi Mill.; } \\
\text { Heather; Manuka, Kanuka }\end{array}$ & $\mathrm{MeOH}$ & $\begin{array}{c}\text { GC-MS; } \\
\text { HPLC-MS/MS }\end{array}$ & {$[79,89]$} \\
\hline \multicolumn{5}{|c|}{ Dihydroxybenzoic acids } \\
\hline Protocatechuic acid & $\begin{array}{c}\text { Acacia, Buckweat, Cornflower, } \\
\text { Manuka, Heather, Pine; Milk } \\
\text { Vetch, Wild Chrysanthemum, } \\
\text { Jujube Flower; Chestnut, } \\
\text { Eucalyptus, Lavender, Rapeseed, } \\
\text { Sunflower, Rosemary, Orange, } \\
\text { Lemon, Black Locust, Sulla, } \\
\text { Echium plantagineum }\end{array}$ & $\begin{array}{c}\mathrm{MeOH} 43 \%(v / v) \text { and } \\
\mathrm{HCOOH}(\mathrm{aq}), \mathrm{pH} 2.54 \\
(57 \%, v / v)\end{array}$ & $\begin{array}{l}\text { HPLV /UV; } \\
\text { HPLC-DAD }\end{array}$ & {$[71,75,84,87]$} \\
\hline
\end{tabular}


Table 2. Cont.

\begin{tabular}{|c|c|c|c|c|}
\hline $\begin{array}{l}\text { Phenolic } \\
\text { Compounds }\end{array}$ & Honey Type & $\begin{array}{c}\text { Extraction } \\
\text { Technique/Extraction } \\
\text { Solvent }\end{array}$ & Spectral Analysis & Referencces \\
\hline \multicolumn{5}{|c|}{ Benzoic acids derivatives } \\
\hline Methyl syringate & $\begin{array}{c}\text { Asphodel, Manuka, Kanuka, } \\
\text { Sulla, Dill, Lemon, Orange, And } \\
\text { Medlar }\end{array}$ & $\begin{array}{c}\text { MeCN } 2 \text { Water:MeCN } \\
\text { 60:40(v/v) }\end{array}$ & $\begin{array}{l}\text { HPLC-DAD; } \\
\text { HPLC-MS/MS }\end{array}$ & {$[70,79]$} \\
\hline \multicolumn{5}{|c|}{ Tanins } \\
\hline $\begin{array}{l}\text { Monogalloyl- } \\
\text { glucose }\end{array}$ & Rosemary & MeOH:water (1:1) & CE-ESI-MS & [69] \\
\hline \multicolumn{5}{|c|}{ Monoterpenoids } \\
\hline Carvacrol & Ziziphus Spina Christi & $\mathrm{MeOH}$ & HPLC-DAD & [90] \\
\hline Thymol & Ziziphus Spina Christi & $\mathrm{MeOH}$ & HPLC-DAD & [90] \\
\hline \multicolumn{5}{|c|}{ Other polyphenols } \\
\hline Chlorogenic acid & $\begin{array}{l}\text { Buckweat, Manuka; Acacia, Milk } \\
\text { Vetch, Wild Chrysanthemum, } \\
\text { Jujube Flower; Acacia, Chestnut, } \\
\text { Savory, Sulla, Ailanthus, } \\
\text { Thymus, Orange }\end{array}$ & $\begin{array}{c}\mathrm{MeOH} ; \mathrm{MeOH} 43 \% \\
(v / v) \text { and } \mathrm{HCOOH}(\mathrm{aq}) \\
\mathrm{pH} 2.54(57 \%, v / v) ; \\
40 / 50 / 10(v / v / v) \\
\text { water/TFA } / \mathrm{MeCN}\end{array}$ & HPLV-UV & {$[68,71,76,84]$} \\
\hline Gallocatechin & $\begin{array}{l}\text { Sweet chestnut, Eucalyptus, } \\
\text { Citrus, Sulla, Sage }\end{array}$ & $\begin{array}{l}\mathrm{MeOH} \\
\mathrm{MeCN}\end{array}$ & $\begin{array}{l}\text { HPLC-MS/MS; } \\
\text { UHPLC-DAD } \\
\text { MS/MS }\end{array}$ & {$[65,89]$} \\
\hline Epigallocatechin & Sage & $\mathrm{MeCN}$ & $\begin{array}{l}\text { UHPLC-DAD } \\
\text { MS/MS }\end{array}$ & [65] \\
\hline $\begin{array}{l}\text { Epigallocatechin } \\
\text { gallate }\end{array}$ & Sage & $\mathrm{MeCN}$ & $\begin{array}{l}\text { UHPLC-DAD } \\
\text { MS/MS }\end{array}$ & [65] \\
\hline Resveratrol & Sage & $\mathrm{MeCN}$ & $\begin{array}{l}\text { UHPLC-DAD } \\
\text { MS/MS }\end{array}$ & {$[65]$} \\
\hline \multicolumn{5}{|c|}{ Other compounds } \\
\hline Phenyllactic acid & $\begin{array}{l}\text { Cornflower, Manuka, Kanuka, } \\
\text { Thistle, Mint, Heather, Sulla, Dill }\end{array}$ & $\mathrm{MeOH}$ & HPLC-MS/MS & {$[70,85,86,89]$} \\
\hline $\begin{array}{l}\text { 2-cis,4-trans- } \\
\text { abscisic } \\
\text { acid }\end{array}$ & $\begin{array}{l}\text { Strawberry tree, manuka, Black } \\
\text { Locust, Buckwheat, Basil, } \\
\text { Goldenrod, Linden, Sunflower, } \\
\text { Rapeseed }\end{array}$ & $\begin{array}{c}\text { MeCN Water/MeCN } \\
60: 40(v / v)\end{array}$ & $\begin{array}{l}\text { HPLC-DAD } \\
\text { HPLC-MS/MS }\end{array}$ & [79] \\
\hline $\begin{array}{l}\text { 2-trans,4-trans- } \\
\text { abscisic } \\
\text { acid }\end{array}$ & $\begin{array}{c}\text { Strawberry tree, Manuka, } \\
\text { Cornflower }\end{array}$ & $\begin{array}{c}\text { MeCN Water/MeCN } \\
60: 40(v / v)\end{array}$ & $\begin{array}{l}\text { HPLC-DAD } \\
\text { HPLC-MS/MS }\end{array}$ & {$[79,91]$} \\
\hline Fisetin & $\begin{array}{c}\text { Lavender, Orange Blossom, } \\
\text { Rosemary, Heather, Eucalyptus, } \\
\text { Chestnut, Thyme }\end{array}$ & $\mathrm{MeCN}$ & HPLC-DAD-TOF-MS & [78] \\
\hline
\end{tabular}

UHPLC, Ultra-High-Performance Liquid Chromatography; LC-MS, Liquid chromatography-mass spectrometry; MeCN, acetonitrile; $\mathrm{MeOH}$, methanol; TFA,trifluoroacetic acid.

In Acacia honeys, eight phenolic compounds and abscisic acid were identified in almost all samples and seemed to exhibit higher levels. These characteristic compounds included vanillic acid, caffeic acid, $p$-coumaric acid, ferulic acid, 3,4-dimethoxycinnamic acid, cinnamic acid, abscisic acid, kaempferol and pinocembrin. These nine characteristic compounds represent practically $50 \%$ of the total phenolics. In Serbian honeys, Kečkeš et al., (2013) [72] demonstrated that Sunflower, Basil, Buckwheat, Canola and Goldenrod honeys are strongly correlated to the phenolic profile. Thus, they demonstrated that quercetin and eriodictyol could be used as floral markers for Serbian honey, as well as cis, trans-Abscisic acid, which clearly distinquished between acacia and linden honeys. 
The chemical constituents of Peppermint honey revealed that the most common compounds are $p$-coumaric acid and kaempferol, as well as a high abundance of methyl syringate, vomifoliol, 3,7-dimethylocta-1,5-dien-3,7-diol (terpendiol I) and hotrienol. Furthemore, the major honey headspace compounds were hotrienol, cis- and trans-linalool oxides, linalool and neroloxide [86].

Useful chemical markers such as carvacrol and thymol were solely found in Ziziphus Spina-Christi honey, as well as kojic acid distinctive to Coffea sp. honey [92,93], Quercetin $3^{\prime}, 3^{\prime}$-dimethyl eter and Quercetin 7,3'-dimethyl eter characteristic in Rosemary honey (Arráez-Román et al., 2006) [69] and resveratrol distinctive to Sage (Salvia officinalis L.) honey (Gašić et al., 2015) [65]. Furthermore, several compounds are useful to discriminate honeys with similar properties and palinological characteristics. This is the case of Manuka (Leptospermum scoparium) and Kanuka (Kunzea erikoides) honeys, which are not distinguished by means of a melissopalynological analysis. Even though they share most of their phenolic profiles, Stephens et al., 2010 [89] noticed that 2-methoxybenzoic acid and trimethoxybenzoic acid are distinctive to Manuka honey, while 4-methoxyphenylacetic acid is characteristic to Kanuka honey. Furthermore, an increasing interest has been noticed in using the polyphenolic profile to distinguish honeys based on their geographic origin. Habib et al., 2014 [79] showed dissimilarities in the phenolic pattern based on the different climate and sunlight exposure. According to their study, sunlight exposure is responsible for higher polyphenol content in honeys produced in dry areas. The phenolic profile of Serbian unifloral honeys was investigated by Kečkeš et al., 2013 [72], who proposed eriodictyol and quercetin as floral markers for local Sunflower honeys. Furthermore, the phenolic profile of Sulla honeys produced in Southern Italy were influenced by their geographical origin [94], whereas the concentrations of gallic, chlorogenic, caffeic, $p$-coumaric and ferulic acids showed the highest variation as a function of the production site of this honey. Furthermore, Weston et al. (1999) [95] presented several methods for isolation of the antibacterial active phenolic fraction of honey derived from the native New Zealand manuka tree Leptospermum scoparium. This fraction consists of phenolic derivatives of benzoic acids, cinnamic acids and flavonoids, all of which have been identified previously in honeys. Regarding manuka honeys, the major flavonoids are pinobanksin, pinocembrin and chrysin, whereas galagin, isorhamnetin, kaempferol, 8-methoxykaempferol, luteolin and quercetinare were identified in minor concentration $[96,97]$.

\section{Physicochemical Properties of Monofloral Honeys}

Honey, a high-quality natural product with a complex chemical composition, contains a wide range of nutritional and therapeutic properties.

The quality is usually assessed by physicochemical, sensorial and microbiological parameters. The physicochemical properties depend on the type of nectar (botanical origin), geographical origin (climate conditions and soil composition) and handling (storage and transport). Multiple studies have reported that the physicochemical parameters of honey, such as moisture, acidity, sugar composition, ash and 5-hydroxymethylfurfural (HMF) are used to distinguish honey types. The physicochemical characteristics of monofloral honeys from different countries are exemplified in Table 3. 
Table 3. Physicochemical properties of monofloral honeys from different geographical origin.

\begin{tabular}{|c|c|c|c|c|c|c|c|}
\hline Honey Type & Origin & $\begin{array}{c}\text { Moisture } \\
\text { Content (\%) }\end{array}$ & $\begin{array}{c}\text { Acidity } \\
(\mathrm{meq} / \mathrm{kg})\end{array}$ & $\begin{array}{c}\text { Sugar Composition } \\
(\%)\end{array}$ & $\begin{array}{l}\text { Ash } \\
(\%)\end{array}$ & $\begin{array}{c}\text { HMF } \\
(\mathrm{mg} / \mathrm{kg})\end{array}$ & Reference \\
\hline $\begin{array}{c}\text { Allium } \\
\text { ursinum L. }\end{array}$ & Hungary & 18.3-19.7 & $19.0-23.5$ & n.i. & n.i. & $15.3-20.6$ & {$[98,99]$} \\
\hline $\begin{array}{c}\text { Arbutus } \\
\text { unedo }\end{array}$ & Portugal & $15.8-19.8$ & 20.17-61.10 & $\begin{array}{l}\text { Fructose: } 35.96 \\
\text { Glucose: } 26.743\end{array}$ & 0.70 & 8.2 & {$[45,100]$} \\
\hline Asclepias sp. & Hungary & 16.9-20.0 & $29.0-34.0$ & $\begin{array}{c}\text { Fructose: } 41.1 \\
\text { Glucose:30.8 }\end{array}$ & n.i. & $20.3-25.0$ & {$[98,99]$} \\
\hline \multirow[t]{3}{*}{ B. napus } & Romania & 18.4 & 16 & $\begin{array}{l}\text { Fructose: } 35.26 \\
\text { Glucose: } 31.78 \\
\text { F/G ratio:1.11 }\end{array}$ & n.i. & 13.3 & [36] \\
\hline & Bulgaria & n.i. & n.i. & $\begin{array}{l}\text { Fructose: } 36.70 \\
\text { Glucose: } 37.46\end{array}$ & n.i. & 40.65 & [101] \\
\hline & Hungary & $17.2-19.8$ & $21.5-27.5$ & $\begin{array}{c}\text { Fructose: } 38.5 \\
\text { Glucose: } 40.5\end{array}$ & n.i. & $0.8-17.9$ & {$[98,99]$} \\
\hline \multirow[t]{2}{*}{$\begin{array}{l}\text { Calluna } \\
\text { vulgaris L. }\end{array}$} & Portugal & 19.0 & 35.23 & $\begin{array}{l}\text { Fructose: } 35.963 \\
\text { Glucose: } 26.743\end{array}$ & 0.48 & 22.80 & {$[100]$} \\
\hline & Turkey & 20.86 & n.i. & $\begin{array}{l}\text { Fructose: } 45.11 \\
\text { Glucose: } 25.00 \\
\text { F/G ratio: } 1.80\end{array}$ & n.i. & 62.24 & [25] \\
\hline $\begin{array}{l}\text { Carlina } \\
\text { racemosa }\end{array}$ & Portugal & 17.2 & 41.37 & $\begin{array}{l}\text { Fructose: } 35.703 \\
\text { Glucose: } 25.020\end{array}$ & 0.55 & n.i. & {$[100]$} \\
\hline \multirow{2}{*}{$\begin{array}{l}\text { Castanea } \\
\text { sativa Mill. }\end{array}$} & Hungary & $17.0-17.4$ & $26.0-32.0$ & n.d. & n.d. & $12.6-33.1$ & {$[98,99]$} \\
\hline & Turkey & 19.70 & n.i. & $\begin{array}{l}\text { Fructose: } 38.44 \\
\text { Glucose: } 19.35 \\
\text { F/G ratio: } 1.98\end{array}$ & n.i. & 9.28 & [25] \\
\hline $\begin{array}{l}\text { Ceratonia } \\
\text { siliqua }\end{array}$ & Portugal & $15.40-18.6$ & $31.72-56.20$ & $\begin{array}{l}\text { Fructose: } 37.964 \\
\text { Glucose: } 26.372\end{array}$ & 0.43 & 41.80 & {$[45,100]$} \\
\hline Cistus sp. & Portugal & 15.90 & 32.0 & n.i. & 0.25 & 20.0 & [102] \\
\hline Citrus sinensis & Portugal & $15.8-18.2$ & $19.40-30.50$ & $\begin{array}{l}\text { Fructose: } 40.180 \\
\text { Glucose: } 27.110\end{array}$ & 0.13 & 28.20 & {$[45,100]$} \\
\hline \multirow{2}{*}{$\begin{array}{l}\text { Coriandrum } \\
\text { sp. }\end{array}$} & Hungary & $19.1-19.3$ & $40.2-43.5$ & n.i. & n.i. & $8.2-14.5$ & {$[98,99]$} \\
\hline & Bulgaria & 16.27 & $4.71-16.09$ & $\begin{array}{l}\text { Fructose: } 40.25 \\
\text { Glucose: } 26.11\end{array}$ & n.i. & $17.38-22.72$ & {$[101,103]$} \\
\hline $\begin{array}{l}\text { Cytisus } \\
\text { scoparius }\end{array}$ & Portugal & 19.70 & 30.0 & n.i. & 0.37 & 6.56 & [46] \\
\hline Echium sp. & Portugal & 16.80 & 25.0 & n.i. & 0.23 & 94.0 & [102] \\
\hline \multirow[t]{2}{*}{ Erica sp. } & Portugal & $17.31-20.60$ & $15.5-47.70$ & $\begin{array}{l}\text { Fructose:34.4-37.1 } \\
\text { Glucose:28.0-33.4 }\end{array}$ & $\begin{array}{l}0.32- \\
0.36\end{array}$ & $4.63-20.40$ & {$[45,46,104]$} \\
\hline & Spain & 18.19 & 35.66 & n.d. & 0.47 & 3.72 & [105] \\
\hline Eucaliptus sp. & Portugal & $14.30-19.20$ & $12.6-29.7$ & $\begin{array}{l}\text { Fructose: } 23.34 \\
\text { Glucose: } 35.82\end{array}$ & $\begin{array}{l}0.07- \\
0.46\end{array}$ & $2.54-32.75$ & $\begin{array}{c}{[46,100,} \\
105]\end{array}$ \\
\hline \multirow{3}{*}{ H. annus } & Romania & $16.23-20.39$ & $15-94-47.32$ & $\begin{array}{l}\text { Fructose: } 36.74 \\
\text { Glucose: } 28.37 \\
\text { F/G ratio: } 1.33\end{array}$ & $\begin{array}{l}0.33- \\
0.36\end{array}$ & $2.66-10.96$ & {$[106,107]$} \\
\hline & Bulgaria & n.i. & n.i. & $\begin{array}{l}\text { Fructose: } 40.91 \\
\text { Glucose: } 35.80\end{array}$ & n.i. & 25.47 & [101] \\
\hline & Portugal & 19.2 & 25.50 & $\begin{array}{l}\text { Fructose: } 41.24 \\
\text { Glucose:38.09 }\end{array}$ & 0.15 & 8.10 & {$[100]$} \\
\hline
\end{tabular}


Table 3. Cont.

\begin{tabular}{|c|c|c|c|c|c|c|c|}
\hline Honey Type & Origin & $\begin{array}{c}\text { Moisture } \\
\text { Content (\%) }\end{array}$ & $\begin{array}{c}\text { Acidity } \\
\text { (meq/kg) }\end{array}$ & $\begin{array}{c}\text { Sugar Composition } \\
(\%)\end{array}$ & $\begin{array}{l}\text { Ash } \\
(\%)\end{array}$ & $\begin{array}{c}\text { HMF } \\
(\mathrm{mg} / \mathrm{kg})\end{array}$ & Reference \\
\hline & Hungary & $17.2-19.7$ & $33.5-46.5$ & $\begin{array}{c}\text { Fructose: } 40.5 \\
\text { Glucose: } 36.5\end{array}$ & n.i. & $0.6-25.2$ & {$[98,99]$} \\
\hline $\begin{array}{l}\text { Honeydew } \\
\text { honey }\end{array}$ & Hungary & 19.9-20.0 & $42.0-48.5$ & $\begin{array}{c}\text { Fructose: } 37.3 \\
\text { Glucose: } 27.6\end{array}$ & n.i. & $19.6-34.2$ & {$[98,99]$} \\
\hline \multirow{3}{*}{$\begin{array}{l}\text { Lavandula } \\
\text { stoechas L. }\end{array}$} & Hungary & $19.0-19.1$ & $29.5-35.5$ & n.i. & n.i. & $1.0-13.0$ & {$[98,99]$} \\
\hline & Portugal & $13.56-19.20$ & $16.40-35.10$ & $\begin{array}{l}\text { Fructose:39.81-41.66 } \\
\text { Glucose: } 26.40-28.52\end{array}$ & $\begin{array}{c}0.09- \\
0.18\end{array}$ & $5.35-12.80$ & {$[45,46,100]$} \\
\hline & Turkey & 17.15 & n.i. & $\begin{array}{l}\text { Fructose: } 32.65 \\
\text { Glucose: } 22.19 \\
\text { F/G ratio: } 1.47\end{array}$ & n.i. & 24.42 & [25] \\
\hline Manuka & $\begin{array}{l}\text { New } \\
\text { Zealand, } \\
\text { Australia, } \\
\text { Malaysia }\end{array}$ & $11.59-20.27 \%$ & $42.67 \pm 3.01$ & $\begin{array}{l}\text { Fructose: } 33.0-40.0 \\
\text { Glucose: } 27.8-36.2\end{array}$ & $\begin{array}{c}0.21 \pm \\
0.01\end{array}$ & $31.53-40.0$ & {$[19,71]$} \\
\hline Tualang & Malaysia & $16.39-22.32$ & $44.92-86.08$ & $\begin{array}{c}\text { Fructose: } 29.60-41.73 \\
\text { Glucose: } 30.00-47.13 \\
\text { F/G ratio: } 0.88\end{array}$ & & $\begin{array}{c}5.08- \\
1226.32\end{array}$ & {$[19,108]$} \\
\hline Gelam & Malaysia & $18.51-20.33$ & $46.50-59.75$ & $\begin{array}{l}\text { Fructose: } 44.90 \\
\text { Glucose: } 50.44 \\
\text { F/G ratio: } 0.89\end{array}$ & & $8.52-10.20$ & {$[19,108]$} \\
\hline Longan & Thailand & 20.11 & 17.60 & $\begin{array}{l}\text { Fructose: } 41.02 \\
\text { Glucose: } 34.91 \\
\text { F/G ratio: } 1.18\end{array}$ & 0.23 & 0.58 & [109] \\
\hline $\begin{array}{l}\text { Mentha } \\
\text { pulegium }\end{array}$ & Portugal & 18.10 & 42.17 & $\begin{array}{l}\text { Fructose: } 36.41 \\
\text { Glucose: } 24.66\end{array}$ & 0.61 & 4.10 & [100] \\
\hline $\begin{array}{l}\text { Menthax } \\
\text { piperita }\end{array}$ & Romania & 17.7 & 26.9 & $\begin{array}{l}\text { Fructose: } 36.03 \\
\text { Glucose: } 27.87 \\
\text { F/G ratio: } 1.30\end{array}$ & 0,15 & 29.2 & [36] \\
\hline Pinus sp. & Turkey & $15.5-15.8$ & $26.5-28.6$ & $\begin{array}{l}\text { Fructose: } 32.1-39.8 \\
\text { Glucose: } 23.67-28.2 \\
\text { F/G ratio: } 1.17-1.68\end{array}$ & $\begin{array}{l}0.50- \\
0.55\end{array}$ & 3.57 & $\begin{array}{c}{[25,110-} \\
113]\end{array}$ \\
\hline Pinus $s p$ & Greece & n.i. & n.i. & $\begin{array}{c}\text { Fructose: } 10.33 \\
\text { Glucose: } 2.52 \\
\text { F/G ratio: } 4\end{array}$ & n.i. & 12.34 & [114] \\
\hline \multirow{2}{*}{$\begin{array}{c}R . \\
\text { pseudoacacia }\end{array}$} & Bulgaria & n.i. & n.i. & $\begin{array}{l}\text { Fructose: } 43.22-42.76 \\
\text { Glucose: } 27.50-24.13\end{array}$ & n.i. & 17.82 & {$[102,115]$} \\
\hline & Hungary & $17.1-19.9$ & $13.0-27.5$ & $\begin{array}{l}\text { Fructose: } 43.6 \\
\text { Glucose: } 29.1\end{array}$ & n.i. & $1.1-29.4$ & {$[98,99]$} \\
\hline \multirow[t]{2}{*}{$\begin{array}{l}\text { Rhododendron } \\
\text { sp }\end{array}$} & Italy & n.d. & 28.00 & $\begin{array}{l}\text { Fructose: } 27.80 \\
\text { Glucose: } 38.20\end{array}$ & n.i. & 3.40 & [40] \\
\hline & Turkey & 18.89 & 34.33 & $\begin{array}{l}\text { Fructose: } 43.58 \\
\text { Glucose: } 23.16 \\
\text { F/G ratio: } 1.88\end{array}$ & n.i. & 3.20 & {$[25,116]$} \\
\hline Rubus sp. & Romania & 18.3 & 27.3 & $\begin{array}{l}\text { Fructose: } 36.30-33.46 \\
\text { Glucose: } 38.15-29.00 \\
\text { F/G ratio: } 1.04-1.26\end{array}$ & 0.340 & 18.7 & {$[36,117]$} \\
\hline Thymus sp. & Romania & 17.3 & 22.5 & $\begin{array}{l}\text { Fructose: } 36.77 \\
\text { Glucose: } 26.86 \\
\text { F/G ratio: } 1.38\end{array}$ & n.i. & 30.8 & [36] \\
\hline
\end{tabular}


Table 3. Cont.

\begin{tabular}{|c|c|c|c|c|c|c|c|}
\hline Honey Type & Origin & $\begin{array}{l}\text { Moisture } \\
\text { Content (\%) }\end{array}$ & $\begin{array}{l}\text { Acidity } \\
\text { (meq/kg) }\end{array}$ & $\begin{array}{c}\text { Sugar Composition } \\
(\%)\end{array}$ & $\begin{array}{l}\text { Ash } \\
(\%)\end{array}$ & $\begin{array}{c}\text { HMF } \\
(\mathrm{mg} / \mathrm{kg})\end{array}$ & Reference \\
\hline & Italy & n.d. & 38.50 & $\begin{array}{l}\text { Fructose: } 37.80 \\
\text { Glucose: } 30.50\end{array}$ & n.i. & 30.40 & [16] \\
\hline & Greece & n.i. & n.i. & $\begin{array}{l}\text { Fructose: } 11.51 \\
\text { Glucose: } 5.15 \\
\text { F/G ratio: } 2.2 \\
\end{array}$ & n.i. & 203 & [114] \\
\hline $\begin{array}{l}\text { Thymus } \\
\text { vulgaris }\end{array}$ & Portugal & $15.80-17.50$ & $37.20-69.50$ & $\begin{array}{l}\text { Fructose:37.04 } \\
\text { Glucose: } 24.79\end{array}$ & 0.45 & 1.60 & {$[45,100]$} \\
\hline \multirow{3}{*}{ Tilia sp. } & Bulgaria & n.i. & n.i. & $\begin{array}{l}\text { Fructose: } 40.13 \\
\text { Glucose: } 27.07\end{array}$ & n.i. & n.i. & [101] \\
\hline & Italy & n.i. & 12.80 & $\begin{array}{l}\text { Fructose: } 37.20 \\
\text { Glucose: } 30.20\end{array}$ & n.i. & 3.50 & [16] \\
\hline & Hungary & $17.6-19.9$ & $21.0-41.5$ & $\begin{array}{l}\text { Fructose: } 40.0 \\
\text { Glucose: } 30.6\end{array}$ & n.i. & $4.3-37.5$ & {$[89,99]$} \\
\hline Ziziphus sp. & Egypt & 15.1-20.20 & $12.5-29.17$ & $\begin{array}{c}\text { Fructose: } 39.5-42.1 \\
\text { Glucose: } 29.5-32.0 \\
\text { F/G ratio: } 1.30-1.36\end{array}$ & 0.178 & $0.6-1.6$ & [118] \\
\hline Hovenia dulcis & South Korea & $17.0-19.73$ & $8.50-33.50$ & $\begin{array}{c}\text { Fructose: } 33.1-44.5 \\
\text { Glucose: } 20.2-29.3 \\
\text { F/G ratio: } 1.27-2.23\end{array}$ & $\begin{array}{l}0.08- \\
0.82\end{array}$ & 0.00 & {$[119,120]$} \\
\hline
\end{tabular}

HMF: Hydroxymethylfurfural; n.i., not identified. According to the European Honey Legislation [121] and the Codex Alimentarius Standards [122], honey moisture should not exceed $20 \%$, with the exception of heather (Calluna sp.), which should not surpass 23-25\%, acidity, should be less than 50 milli-equivalents (MEQ) acid/ $\mathrm{kg}$, with glucose and fructose composition not less than $60 \mathrm{~g} / 100 \mathrm{~g}$ and HMF not more than $40 \mathrm{mg} / \mathrm{kg}$, except honeys from tropical climates which should not be more than $80 \mathrm{mg} / \mathrm{kg}$. As it can be foreseen, in some monofloral honeys, the acidity surpasses $50 \mathrm{MEQ} / \mathrm{kg}$, possibly indicating the presence of undesirable fermentations, such as: Arbutus sp., Ceratonia sp. and Thymus sp. from Portugal. Based on their botanical origin, nectar honeys have low ash content compared to honeydew honey.

Generally, the moisture content is an indicator of honey's freshness, being useful to improve its conservation, storage and prevent the growth of moulds (Penicilium and Mucors). The growth of mould gives an off-taste due to the growth levels of ethanol, butanediol and glycerol, which reduce the products quality. Furthermore, the moisture content is a useful parameter in describing the viscosity and moistness of honey. As previously stated, in Codex Alimentarius (2001) [122] and EU Council directives [121], the maximum moisture content value of Erica monofloral honey should not exceed $23 \%$ and $20 \%$ in other monofloral honeys. The moisture content varies depending on external factors, such as environment and harvesting period, and internal factors such as the maturity reached in the hive [123]. In most blossom honeys, fructose and glucose represent the great majority of honey sugars. According to Codex Alimentarius, the sum of fructose and glucose must be more than $60 \%$ for nectar honey and $45 \%$ for honeydew honey. The sucrose content should not exceed $5 \%$, with few exceptions such as the Lavender honey. As can be seen in Table 3, the HMF exceeded $40 \mathrm{mg} / \mathrm{kg}$ in the monofloral honeys of Brassica sp. (Bulgaria), Calluna sp. (Turkey), Ceratonia sp. and Echium sp. (Portugal). Several studies reported slightly higher moisture content in Calluna sp. (Turkey), Erica sp. (Portugal) and H. annus (Romania). Comparatively, the physicochemical characteristics of monofloral honeys originating from Spain were in accordance with the indicated international standards. Bentabol Manzanares et al., (2014) [124] determined the physicochemical characteristics of heather, avocado, oregano, barilla (Messembryanthemum crystallinum), 
malpica (Carlina xeranthemoides), poleo (Bystropogon origanifolius), relinchón (Hirstfeldia incana) and tedera (Aspalthium bituminosum) in monofloral honeys. The lowest moisture content $(15.1 \mathrm{~g} / 100 \mathrm{~g})$ is noticed in relinchón honey and the highest value $(18.4 \mathrm{~g} / 100 \mathrm{~g})$ in barrilla honey, whereas the moisture of heather $(17.24 \mathrm{~g} / 100 \mathrm{~g})$ is similar to those reported by other researchers $[45,46,104]$. Furthermore, the HMF ranged between 5.36-15.00 $(\mathrm{mg} / \mathrm{kg})$ in Barilla and Oregano honeys, respectively.

In the study conducted by Bouhlali et al., 2019 [50], the water content of the monofloral honey present in Morroco was found to be from 14.55 to $20.99 \%$, the water activity level varied between 0.49 and $0.58 \%$, whereas the total acidity (directly associated to $\mathrm{pH}$ and free acidity) had values between 23.55 and $43.53 \mathrm{meq} / \mathrm{kg}$. Furthermore, the highest fructoseglucose ratio (>1.5) belonged to eucalyptus and reseda honey samples.

Due to handling and processing inconveniences, honey has the tendency to crystallize. To avoid this, thermal processing is applied to avoid crystal formation, as well as microbial contamination [125]. Nonetheless, thermal treatment is followed by undesirable consequences, such as colour changing or browning of honey, but also the formation of HMF, an important quality parameter of honey. It is an indicator of honey freshness and overheating of honey leads to conversion in the cytotoxic and mutagenic compound 5-sulfoxymethyfurfural, which can also be generated under inadequate handling and storage conditions (temperature, $\mathrm{pH}$, moisture) [126]. In fresh honeys there is practically no HMF, or it is in very low content; however, it increases upon storage [127]. Council Directive (2001/110/CE) [121] demands a maximum of $40 \mathrm{mg} / \mathrm{kg}$ of HMF in honey. The proposal for a higher maximum value of HMF $(80 \mathrm{mg} / \mathrm{kg})$ in some countries is based on the experience that HMF increases in honey stored in warm climate countries.

In a recent study, Park et al., (2020) [119] evaluated the physicochemical properties, mineral content and antibacterial activity of Hovenia monofloral honey. Their results showed that Hovenia monofloral honey was composed of glucose $(29.0 \pm 0.42 \%)$, fructose $(35.9 \pm 0.78 \%)$, moisture $(18.9 \pm 0.28 \%)$, reducing sugar $(64.9 \pm 0.35 \%)$, sucrose $(3.9 \pm 1.63 \%)$, ash $(0.1 \pm 0.00 \%)$ and $\operatorname{HMF}(0.00 \pm 0.00 \%)$.

Currently one of most innovative commercial products available on the market is Manuka honey [128], which is a monofloral dark honey. The chemical composition and the variety of beneficial nutritional and health effects of manuka honey are revised by Alvarez-Suarez et al. (2014) [55]. It is derived from the manuka tree Leptospermum scoparium (Myrtaceae family). The manuka tree grows as a shrub or a small tree in New Zealand and eastern Australia [56]. This type of honey has attracted the attention of several researchers for its biological properties, especially for its antimicrobial and antioxidant activity [55].

The composition of Manuka honey is mainly of carbohydrates, mineral elements, proteins, fatty acids and phenolic and flavonoid compounds. One of the major antibacterial components of Manuka honey is methylglyoxal (MGO) [129]. Sugars are the main components in Manuka honey. The authors identified fructose, glucose, sucrose and maltose in all honey samples. Fructose and glucose are the main monosaccharides. The content of fructose is higher compared to the glucose content. The content of fructose plus glucose of manuka honey $(60.7 \mathrm{~g} / 100 \mathrm{~g})$ was similar to that reported by Moniruzzaman et al. (2013a) [130]. The sum of fructose and glucose in Manuka honeys is higher than 60\%, which is in accordance with Codex Alimentarius (2001).

Methylglyoxal is also found in Leptospermum scoparium (manuka) and Kunzea ericoides (kanuka) honeys. Manuka honey contains high concentrations of trimethoxybenzoic acid and methylglyoxal, whreas Kanuka honey contains a high concentration of methoxyphenyllactic acid. The phenolic components increase with maturation in both honey types [90]. According to Beitlich et al. (2014) [131], nonvolatiles profiles of manuka honey show leptosin, acetyl2-hydroxy-4-(2-methoxyphenyl)-4-oxobutanate, 3-hydroxy-1-(2-methoxyphenyl)-penta-1,4dione, kojic acid and 5-methyl-3-furancarboxylic acid as predominant. Kanuka honey is characterized by the folowing nonvolatiles compounds: 4-methoxyphenyllactic acid, methyl syringate, $\mathrm{p}$-anisic acid and lumichrome, whereas volatile compounds for manuka honey are 2-Methylbenzofuran, 2'-hydroxyacetophenone and 2'-methoxyacetophenone, whereas kanuka 
honey was characterized by 2,6,6-trimethyl-2-cyclohexene-1,4-dione, phenethyl alcohol and p-anisaldehyde.

Manuka honey has a relatively low $\mathrm{pH}$ (about 3.5-4.5), which contributes to the inhibition of microbial growth [132]. Furthermore, the low levels of wound $\mathrm{pH}$ can reduce protease activity and increase fibroblast activity and wound healing $[133,134]$.

According to Kato et al. (2012) [56], a novel glycoside, leptosin is a characteristic compound of manuka honey. Furthermore, as this type of honey has a low $(11,59 \%)$ moisture content [130], it allows a long-time protection against microbial attacks [131]. Honey from Koompassia excels (Tualang) contains more free radical scavenging, antioxidant activity, flavonoids and phenolic acids, and its health benefits are better compared to other local Malaysian honeys, such as Manuka honey [132]. According to Mohamed et al. (2010) [53], the tualang-derived honey has good colour intensity and contains phenolic compounds that possess relatively good antioxidant activity.

\section{Major Mineral Composition of Some Monofloral Honey}

Generally, the mineral content in honey is low ranging between 0.02 and $0.3 \%$. It is influenced by the nectars chemical composition which varies according to soil composition (geographical origin) and floral type (botanical origin). Variations of soil and climatic conditions may also influence the mineral composition, as well as the extraction method and harvesting techniques [135-137].

According to the International Honey Commision (2009) [137], requirements in individual countries include parameters such as diastase activity (general, no less than eight on the Schade scale), electrical conductivity (e.g., in honeydew honey, no less than $0.8 \mathrm{mS} / \mathrm{cm}$ ), HMF (general, no more than $40 \mathrm{mg} / \mathrm{kg}$ ), free acidity (in general, no more than 50 milliequivalents acid/1000 g), proline (no less than $25 \mathrm{mg} / 100 \mathrm{~g}$ ) and $\mathrm{pH}$, insoluble impurities (no more than $0.1 \mathrm{~g} / 100 \mathrm{~g}$ ).

The most significant minerals in honeys are Potassium (K), Magnesium (Mg), Calcium $(\mathrm{Ca})$ and Sodium $(\mathrm{Na})$. Less abundant elements are Iron $(\mathrm{Fe})$, Copper $(\mathrm{Cu})$, Manganese $(\mathrm{Mn})$ and Chlorine (Cl), followed by trace elements of Borron (B), Phosphorous (Ph), Sulfur (S), Silicon (Si) and Nickel (Ni), among others [138]. Due to its fast secretion by nectar sources, $\mathrm{K}$ is the main element, reaching almost $80 \%$ of the total content [137]. Multiple studies have been conducted to classify monofloral honeys by their mineral composition [139-143].

Honey has also been regarded as a potential environment pollution indicator, as a result of a bio-accumulative process in the borders of urban and industrial areas, as well as in extra-urban crossroads, where traces of some mineral compounds and/or heavy metals were found [144].

As can be seen in Table 4, the monofloral honeys from Spain are abundant in $\mathrm{K}, \mathrm{Ca}$ and $\mathrm{Mg}$, ranging between $2.70-530.0,23.00-387.0$ and $41.0-331.0 \mathrm{mg} \mathrm{kg}^{-1}$ respectively. High discrepancy was noticed in the case of Na content, ranging between 9.18 and 1321.40 $\mathrm{mg} \mathrm{kg}^{-1}$. The honeys from Portugal exhibited high potassium content, accounting for $76 \%$ with an average content of $1150.1 \mathrm{mg} \mathrm{g}^{-1}$. Except for the honeys from Spain, which exhibited high amounts of $\mathrm{Na}$, research from other countries revealed $\mathrm{K}$ to be the most abundant mineral. Furthermore, from the monofloral samples of Morocco, $\mathrm{K}$ was the predominant mineral, followed by $\mathrm{Na}, \mathrm{Ca}$ and $\mathrm{Mg}$, which were found in the highest amount in carob honey [50], whereas the mineral contents of Hovenia monofloral honey included Ca $\left(20.1 \pm 1.06 \mathrm{mg} \mathrm{L}^{-1}\right), \mathrm{K}\left(407.5 \pm 3.11 \mathrm{mg} \mathrm{L}^{-1}\right), \mathrm{P}\left(20.6 \pm 1.77 \mathrm{mg} \mathrm{L}^{-1}\right), \mathrm{Mg}$ $\left(10.7 \pm 1.1 \mathrm{mg} \mathrm{L}^{-1}\right), \mathrm{Na}\left(1.8 \pm 0.28 \mathrm{mg} \mathrm{L}^{-1}\right)$, and $\mathrm{Zn}\left(\right.$ Zinc) $\left(13.9 \pm 15.1 \mathrm{mg} \mathrm{L}^{-1}\right)$. 
Table 4. Monofloral honeys mineral content from different countries.

\begin{tabular}{|c|c|c|c|c|c|c|}
\hline Honey Type & Origin & $\mathrm{K}(\mathrm{mg} / \mathrm{kg})$ & $\mathrm{Mg}(\mathrm{mg} / \mathrm{kg})$ & Ca $(\mathrm{mg} / \mathrm{kg})$ & $\mathrm{Na}(\mathrm{mg} / \mathrm{kg})$ & References \\
\hline Acacia mangium & Malaysia & $1459.33-413.63$ & $44.97-21.83$ & $119.80-567.27$ & $458.95-180.23$ & [144] \\
\hline Arbutus unedo & Portugal & 1736.29 & 24.92 & 50.00 & 161.02 & [100] \\
\hline Asclepias sp. & Hungary & $262-342$ & $6.81-8.88$ & $17.8-24.1$ & $4.51-5.92$ & {$[48]$} \\
\hline \multirow{4}{*}{ Brassica sp. } & Romania & $194.17-112.56$ & $23.90-23.47$ & $88.63-87.14$ & $47.96-36.08$ & [145] \\
\hline & Bulgaria & 105 & 11 & 46 & 8.49 & [146] \\
\hline & Hungary & $162-292$ & $11.2-16.9$ & $33.4-50.6$ & $6.13-9.09$ & {$[48]$} \\
\hline & Hungary & $160-280$ & $11-16$ & $36-48$ & $5.6-12$ & [47] \\
\hline \multirow{4}{*}{ C. sativa } & Bulgaria & 16.28 & 16 & 66 & 9.55 & [146] \\
\hline & Spain & $221.2-269.4$ & $107.89-962.64$ & $122.16-111.42$ & $22.30-26.20$ & [147] \\
\hline & Italy & $290.00-5300$ & $45.0-201.0$ & $23.00-352.0$ & $64.0-104.0$ & [148] \\
\hline & Hungary & $1563-2186$ & $30.1-41.2$ & $81.9-116$ & $10.8-14.6$ & [48] \\
\hline Calluna vulgaris & Portugal & 1196.31 & 31.51 & 45.15 & 155.45 & [100] \\
\hline Carlina racemosa & Portugal & 1341.16 & 46.63 & 42.12 & 208.10 & [100] \\
\hline Ceratonia siliqua & Portugal & 723.28 & 46.89 & 79.09 & 138.10 & [100] \\
\hline Citrus limon L. & Italy & $186-3110$ & $59.00-152$ & $36.00-289$ & $41.00-118.0$ & [148] \\
\hline \multirow{2}{*}{ Citrus sinensis } & Portugal & 170.07 & 9.81 & 28.18 & 56.34 & [100] \\
\hline & Spain & 735.21 & 54.15 & 43.10 & 12.04 & [146] \\
\hline $\begin{array}{c}\text { Citrus sp. } \\
\text { Orange } \\
\text { blossom }\end{array}$ & Italy & $168.00-3016.0$ & $84.00-202.00$ & $177.00-318.00$ & $39.00-145.00$ & [148] \\
\hline $\begin{array}{l}\text { Coriandrum } \\
\text { sativum }\end{array}$ & Bulgaria & 564 & 7.1 & 44 & 14.20 & [149] \\
\hline Cytisus scoparius & Portugal & 160.06 & 31.97 & 71.41 & 101.22 & {$[46]$} \\
\hline Erica sp. & Portugal & 166.70 & 36.78 & 35.14 & 174.45 & [46] \\
\hline \multirow{2}{*}{ Eucalyptus sp. } & Italy & $112.0-372.0$ & $42.00-331.0$ & $84.0-232.0$ & $293.0-928.0$ & [148] \\
\hline & Portugal & $397.17-2040.50$ & $25.04-48.84$ & $19.90-122.45$ & $151.62-667.39$ & {$[46,100]$} \\
\hline Forest honey & Hungary & $1331-2212$ & $39.7-60.2$ & $52.4-75.5$ & $10.8-17.9$ & [48] \\
\hline Gelam & Malaysia & 1363.40 & 31.63 & 275.77 & 196.84 & {$[19,109]$} \\
\hline \multirow{4}{*}{ H. annus } & Romania & $234.64-1111.1$ & $24.9-30.3$ & $67.7-97.4$ & $13.2-36.4$ & [145] \\
\hline & Bulgaria & $280-247$ & 14 & 71 & 7.58 & {$[33,149]$} \\
\hline & Portugal & 276.86 & 24.92 & 68.18 & 87.93 & [100] \\
\hline & Hungary & $502-735$ & $21.8-33.3$ & $82.9-124$ & $6.37-9.32$ & {$[48]$} \\
\hline $\begin{array}{c}\text { Hedysarum } \\
\text { coronarium L }\end{array}$ & Italy & $227.0-295.0$ & $92.0-134.0$ & $188.0-291.0$ & $519.0-681.30$ & [148] \\
\hline $\begin{array}{l}\text { Lavandula } \\
\text { stoechas }\end{array}$ & Portugal & 78.09-173.17 & $6.84-14.46$ & $13.38-32.43$ & 41.47-95.02 & {$[46,100]$} \\
\hline $\begin{array}{l}\text { Dimocarpus } \\
\text { longan Lour. }\end{array}$ & Malaysia & 906.35 & 35.47 & 118.07 & 95.94 & [144] \\
\hline $\begin{array}{l}\text { Mentha } \\
\text { pulegium }\end{array}$ & Portugal & 158.256 & 70.92 & 39.09 & 161.64 & [100] \\
\hline $\begin{array}{c}\text { Pauliurus spina } \\
\text { christi }\end{array}$ & Bulgaria & 1198 & 17 & 62 & 11.80 & [146] \\
\hline $\begin{array}{c}\text { Persea americana } \\
\text { Mill. }\end{array}$ & Spain & 557.073 & 623.58 & 55.97 & 69.05 & [141] \\
\hline
\end{tabular}


Table 4. Cont.

\begin{tabular}{|c|c|c|c|c|c|c|}
\hline Honey Type & Origin & K (mg/kg) & $\mathrm{Mg}(\mathrm{mg} / \mathrm{kg})$ & Ca (mg/kg) & $\mathrm{Na}(\mathrm{mg} / \mathrm{kg})$ & References \\
\hline $\begin{array}{c}\text { Phacelia } \\
\text { tanacetifolia }\end{array}$ & Hungary & $102-130$ & $4.09-5.16$ & $9.12-12.5$ & $3.02-3.81$ & {$[48]$} \\
\hline $\begin{array}{l}\text { Ananas comosus } \\
\text { (L.) Merr. }\end{array}$ & Malaysia & 473.68 & 36.63 & 74.60 & 111.29 & [144] \\
\hline Pinus sp. & Turkey & 1832-1989 & $54.2-59.2$ & $50.1-59.9$ & n.i. & {$[110,111,113]$} \\
\hline \multirow{4}{*}{ R. pseudoacacia } & Italy & $400-1150$ & $41.0-93.0$ & $55.0-182.0$ & $60.0-1190$ & [148] \\
\hline & Romania & $244.58-146.66$ & $6.72-3.25$ & $6.94-1.02$ & $24.32-8.32$ & {$[150,151]$} \\
\hline & Bulgaria & $250-126$ & 6.0 & 32.0 & 8.11 & {$[34,145,149]$} \\
\hline & Hungary & $115-176$ & $3.83-5.30$ & $10.2-15.5$ & $3.13-4.62$ & [48] \\
\hline $\begin{array}{l}\text { Rosmarinus } \\
\text { officinalis L } \\
\text { (Rosemary) }\end{array}$ & Spain & $253.00-553.03$ & $9.80-42.11$ & 15.14-206.70 & $9.18-36.80$ & {$[141,147]$} \\
\hline \multirow{2}{*}{$\begin{array}{c}\text { Thymus vulgaris } \\
\text { L }\end{array}$} & Portugal & 341.91 & 74.15 & 68.79 & 61.30 & [100] \\
\hline & Spain & $322.45-1502.00$ & $40.70-341.74$ & 98.10-181.69 & 36.0-151.65- & [147] \\
\hline \multirow{2}{*}{ Tilia sp. } & Bulgaria & $112.3-796$ & 21 & 77 & 7.50 & {$[34,146]$} \\
\hline & Hungary & 921-1280 & $17.1-24.9$ & 71.8-98.3 & 10.1-13.9 & [48] \\
\hline $\begin{array}{c}\text { Kompassia } \\
\text { excelsa }\end{array}$ & Malaysia & 1576.40 & 35.03 & 165.10 & 268.23 & [144] \\
\hline Vicia sp. & Bulgaria & 196 & 10 & 33 & 9.62 & [146] \\
\hline Wildflower & Italy & $270-2460$ & $85.0-184.0$ & $168.0-387.0$ & $322.8-1321.4$ & [148] \\
\hline Ziziphus sp. & Egypt, Palestina & $1569.3-476.40$ & $34.48-22.1$ & $136.6-94.56$ & $115.04-49.2$ & [118] \\
\hline Hovenia dulcis & South Korea & $\begin{array}{c}405.3-409.7 \\
\mathrm{mg} / \mathrm{L}\end{array}$ & 9.9-11.5 & 19.3-20.8 & $1.6-2.0$ & {$[120,150,152]$} \\
\hline
\end{tabular}

In their extensive review, Solayman et al., 2015 [153] reported detailed information regarding the physicochemical properties of honey, particularly the mineral and heavy metal contents, as well as their medicinal properties.

\section{Antioxidant Activity of Monofloral Honeys}

Phenolic compounds are mostly divided into two main groups: flavonoids and phenolic acids. Honey contains a significant number of polyphenolic compounds, widely used as plant origin and honey quality indicators. The total phenolic content (TPC) and total flavonoid content (TFC) are well-known criteria for the initial assessment of the bioavailability of honey and other bee products.

Worldwide, multiple studies assessed the antioxidant activity of monofloral honeys. This research is often accompanied by the measure of some spectrophotometric parameters such as TPC and TFC, as well as the electrical conductivity and/or colour. In fewer cases, these studies are accompanied by additional characteristics, such as: melissopalynological analysis, chromatographic phenolic profile or mineral composition of major and trace elements. In the last decade, multiple studies have evaluated the antimicrobial, antioxidants and radical scavenging properties of monofloral honeys from different geographical origin, such as: Burkina Fasan, Hungary, Italy, Poland, Portugal, Turkey and Malaysia. Table 5 summarises a selection of monofloral honeys' antioxidant activity. 
Table 5. Phenolic compounds, antioxidant capacity, and in vitro pharmacological studies of monofloral honeys.

\begin{tabular}{|c|c|c|c|c|c|c|}
\hline Honey Type & Origin & $\begin{array}{c}\text { TPC (mg GAE/100 } \\
\text { g) }\end{array}$ & $\begin{array}{c}\text { TFC (mg QE/100 } \\
\text { g) }\end{array}$ & Antioxidant Activity & In Vitro Pharmacological Activity & Reference \\
\hline $\begin{array}{c}\text { Acacia Honey (Acacia } \\
\text { sp.) }\end{array}$ & $\begin{array}{c}\text { Burkina Fasan, } \\
\text { Pakistan, Malaysia }\end{array}$ & $\begin{array}{l}93.43-14.70 \mathrm{mg} \\
\text { GAE } / 100 \mathrm{~g}\end{array}$ & $\begin{array}{l}6.14-1.13 \mathrm{mg} \\
\mathrm{QE} / 100 \mathrm{~g}\end{array}$ & $\begin{array}{c}\text { DPPH, } \mathrm{IC}_{50}(\mathrm{mg} / \mathrm{mL}): \\
\text { between } 10.40-17.97 \\
\text { ABTS }(176.66-231.5 \\
\mu \mathrm{mol} \text { TE/g) ORAC } \\
(30.62-83.72 \mu \mathrm{mol} \mathrm{TE} / \mathrm{g})\end{array}$ & $\begin{array}{c}\downarrow \text { IL } 1 \beta \text { level and } \\
\downarrow \text { TNF- } \alpha \text { level after } 24 \mathrm{~h} \text { with increase in } \\
\text { honey concentration } 1-8 \%(v / v) \\
\uparrow \text { calcium ion level from } 24 \text { to } 48 \mathrm{hrs} \\
\text { incubation periods } \\
\uparrow \text { anticancer activity on PC-3 cell line after } \\
24 \text { hrs incubation with } \text { IC }_{50}: 4.43 \%(v / v) \\
\downarrow \text { Cell viability and } \\
\uparrow \text { Apoptotic cell death in MCF-7 breast } \\
\text { cancer cells at 3.12-100\% (v/v) for } 24-72 \mathrm{hrs} \\
\downarrow \text { TNF- } \alpha, \text { IL-1 } \beta, \text { Ca ion in NCI-H460 } \\
\text { non-small lung cancer cells }\end{array}$ & [154-167] \\
\hline $\begin{array}{c}\text { Astragalus honey } \\
\text { (Astragalus microcephalus } \\
\text { Willd) }\end{array}$ & $\begin{array}{l}\text { Turkey, } \\
\text { Iran }\end{array}$ & $198.00 \mathrm{CE} / 100 \mathrm{~g}$ & $23.57 \mathrm{mg} Q E / 100 \mathrm{~g}$ & DPPH: $7.2 \mathrm{mg} / \mathrm{mL}$ & $\begin{array}{c}\downarrow \text { in Bcl-2 mRNA expression } \\
\downarrow \text { Bcl-2 gene in 5637cells } \\
\downarrow \text { p53 gene in HepG2 cells } \\
\downarrow \text { expression of the p53 gene by } 80 \% \text { in } 5637 \\
\text { cells } \\
\leftrightarrow \text { to } \downarrow \text { p53 gene expressions in L929 cells }\end{array}$ & [158] \\
\hline $\begin{array}{l}\text { Berry honey } \\
\text { Rubus sp. }\end{array}$ & Romania & $\begin{array}{c}19.9 \mathrm{mg} \mathrm{GAE} / 100 \\
\mathrm{~g}\end{array}$ & $33.5 \mathrm{mg} Q \mathrm{QE} / 100 \mathrm{~g}$ & DPPH: $79.05 \%$ & n.i. & [36] \\
\hline $\begin{array}{l}\text { Black locust honey } \\
\text { (Robinia pseudoacacia) }\end{array}$ & $\begin{array}{l}\text { Malaysia, Poland, } \\
\text { Turkey, Romania }\end{array}$ & $\begin{array}{l}2.0-39.0 \mathrm{mg} \\
\mathrm{GAE} / 100 \mathrm{~g}\end{array}$ & $\begin{array}{l}0.91-2.42 \mathrm{mg} \\
\mathrm{QE} / 100 \mathrm{~g}\end{array}$ & $\begin{array}{c}\text { DPPH: 12.72-29.98 mg } \\
\text { GAE/100 g honey; } \\
\text { FRAP: } 82.39 \text { mg TE/100 } \\
\text { g }\end{array}$ & $\begin{array}{c}\downarrow \text { LPO in liver } \\
\downarrow \text { Cell viability in B16-F1 cells after } 24 \text { hrs at } \\
\text { doses of } 0.2 \text { and } 0.1 \mathrm{~g} / \mathrm{mL} \\
\downarrow \text { Cell viability in A375 line observed after } \\
48 \text { - and } 72 \text {-h exposure of cells to } 0.2 \text { and } 0.1 \\
\mathrm{~g} / \mathrm{mL} \text { doses of acacia honey } \\
\downarrow \text { Cell viability and } \downarrow \text { Bcl-2, p53 in } \\
\text { NCI-H460 non-small lung cancer cells at } \\
0.5-8 \%(w / v) \text { for } 48 \text { hrs } \\
\text { Arrest cell cycle at G0/G1 phase in B16-F1 } \\
\text { and A375 line }\end{array}$ & {$[18,24,159-161]$} \\
\hline
\end{tabular}


Table 5. Cont.

\begin{tabular}{|c|c|c|c|c|c|c|}
\hline Honey Type & Origin & $\begin{array}{c}\text { TPC (mg GAE/100 } \\
\text { g) }\end{array}$ & $\begin{array}{c}\text { TFC (mg QE/100 } \\
\text { g) }\end{array}$ & Antioxidant Activity & In Vitro Pharmacological Activity & Reference \\
\hline & Italy & $112.99 \mathrm{mg} \mathrm{GAE} / \mathrm{kg}$ & $67.32 \mathrm{mg} \mathrm{QE} / \mathrm{kg}$ & $\begin{array}{c}\text { DPPH, } \mathrm{IC}_{50}(\mathrm{mg} / \mathrm{mL}): \\
21.56 \\
\text { FRAP, (mmol Fe(II)/Kg } \\
\text { honey): } 1.377\end{array}$ & n.i. & [76] \\
\hline & Poland & $142.8 \mathrm{mg} \mathrm{GAE} / \mathrm{kg}$ & n.a. & $\begin{array}{c}\text { DPPH, }(\mathrm{mmol} \\
\text { TEAC } / \mathrm{kg}): 0.3 \\
\text { FRAP, }(\mathrm{mmol} \mathrm{Fe}(\mathrm{II}) / \mathrm{Kg} \\
\text { honey): } 0.6\end{array}$ & n.i. & [87] \\
\hline $\begin{array}{l}\text { Buckwheat honey } \\
\text { (Fagopyrum esculentum) }\end{array}$ & Poland & $\begin{array}{l}1113.0 \mathrm{mg} \\
\mathrm{GAE} / 100 \mathrm{~g}\end{array}$ & n.a. & $\begin{array}{c}\text { DPPH, }(\mathrm{mmol} \\
\text { TEAC } / \mathrm{kg}): 1.2 \\
\text { FRAP, }(\mathrm{mmol} \mathrm{Fe}(\mathrm{II}) / \mathrm{Kg} \\
\text { honey): } 5.7\end{array}$ & $\begin{array}{c}\uparrow \text { ROS inhibition produced by human } \\
\text { PMNs (160 to } 130 \mathrm{~mL} / \mathrm{g} \text { activity) } \\
\uparrow \text { Superoxide anion scavenging inhibition } \\
\text { (RIC50: } 290 \mathrm{~mL} / \mathrm{g} \text { ) } \\
\downarrow \text { oxidative stress, } \downarrow \text { LPO in liver }\end{array}$ & {$[87,162]$} \\
\hline \multirow[t]{2}{*}{ Canola (B. napus) } & Poland & $\begin{array}{l}47.71-183.0 \mathrm{mg} \\
\mathrm{GAE} / 100 \mathrm{~g}\end{array}$ & $0.72 \mathrm{mg} \mathrm{CEQ} / 100 \mathrm{~g}$ & $\begin{array}{c}\text { DPPH: } 55.4 \% \\
\text { DPPH: } 18.22 \mu \mathrm{mol} \mathrm{TE} / \\
100 \mathrm{~g} \\
\text { FRAP: } 92.05 \mu \mathrm{mol} \\
\text { TE } / 100 \mathrm{~g} \\
\text { TEAC: } 67 \mu \mathrm{mol} \mathrm{TE} / 100 \mathrm{~g}\end{array}$ & $\downarrow$ Superoxide radical, $\downarrow$ LPO & {$[47,87,163]$} \\
\hline & Romania & $\begin{array}{c}23.7-19.9 \mathrm{mg} \\
\mathrm{GAE} / 100 \mathrm{~g}\end{array}$ & $\begin{array}{l}20.2-2.5 \mathrm{mg} \\
\mathrm{QE} / 100 \mathrm{~g}\end{array}$ & n.i. & n.i. & {$[36,164]$} \\
\hline $\begin{array}{l}\text { Chestnut honey } \\
\text { (Castanea sativa) }\end{array}$ & Italy & $\begin{array}{l}14.26-94.56 \mathrm{mg} \\
\text { GAE } / 100 \mathrm{~g}\end{array}$ & $\begin{array}{c}12.52-143.63 \mathrm{mg} \\
\mathrm{QE} / 100 \mathrm{~g}\end{array}$ & DPPH, I\% (\%): 75.37 & $\begin{array}{c}\downarrow \text { Oxidative stress } \\
\uparrow \text { inhibition of LPS-induced NO } \\
\uparrow \text { antimutagenic activity on TA98 strain (10 } \\
\mu \mathrm{g} / \mathrm{mL} \text { to } 20 \mathrm{mg} / \mathrm{mL} \text { honey concentration) } \\
\uparrow \text { Apoptotis in MCF-7 cell line after } 48 \mathrm{~h} \text { at } \\
2.5 \text { and } 5 \mathrm{mg} / \mathrm{mL} \text { doses } \\
\uparrow \text { Apoptotis in SKBR-3 cell line at } 5 \mathrm{mg} / \mathrm{mL} \\
\text { dose of chestnut honey }(62.05 \% \text { cell death) } \\
\leftrightarrow \text { apoptosis at } 5 \mathrm{mg} / \mathrm{mL} \text { dose on } \\
\text { MDA-MB- } 231 \text { ( } 25.87 \% \text { cell death) } \\
\leftrightarrow \text { apoptosis at } 5 \mathrm{mg} / \mathrm{mL} \text { dose of the } \\
\text { chestnut honey on MCF-10A ( } 31.5 \% \text { cell } \\
\text { death) }\end{array}$ & $\begin{array}{c}{[44,45,62,68,76,165-} \\
168]\end{array}$ \\
\hline
\end{tabular}


Table 5. Cont

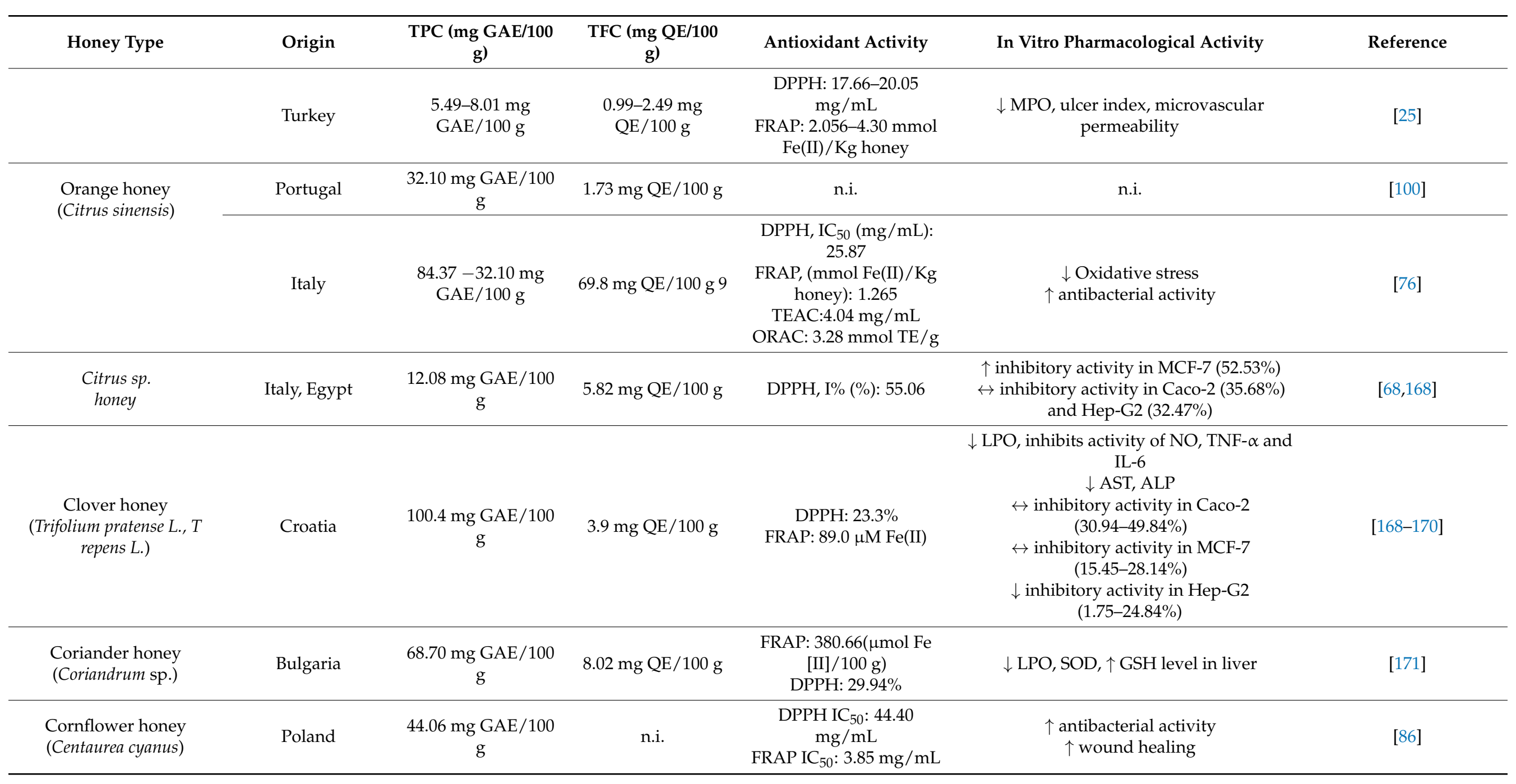


Table 5. Cont.

\begin{tabular}{|c|c|c|c|c|c|c|}
\hline Honey Type & Origin & $\begin{array}{c}\text { TPC (mg GAE/100 } \\
\text { g) }\end{array}$ & $\begin{array}{c}\text { TFC (mg QE/100 } \\
\text { g) }\end{array}$ & Antioxidant Activity & In Vitro Pharmacological Activity & Reference \\
\hline $\begin{array}{l}\text { Cotton honey } \\
\text { (Gossypium sp.) }\end{array}$ & Egypt & $\begin{array}{l}45.42 \mathrm{mg} \mathrm{GAE} / 100 \\
\mathrm{~g}\end{array}$ & & $\begin{array}{c}\mathrm{DPPH}\left(\mathrm{SC}_{50}(\mu \mathrm{g} / \mathrm{mL})\right. \\
99.40 \\
\text { ABTS }^{+} \mathrm{SC}_{50}(\mu \mathrm{g} / \mathrm{mL}) \\
41.20\end{array}$ & $\begin{array}{c}\leftrightarrow \text { inhibitory activity in MCF-7 (32.91\%) } \\
\downarrow \text { inhibitory activity in Caco-2 (29.25\%) and } \\
\text { Hep-G2 (20.08\%) }\end{array}$ & [168] \\
\hline \multirow{2}{*}{$\begin{array}{l}\text { Eucalyptus honey } \\
\text { (Eucalyptus sp.) }\end{array}$} & Portugal & $\begin{array}{c}54.25 \mathrm{mg} \mathrm{GAE} / 100 \\
\mathrm{~g}\end{array}$ & $5.28 \mathrm{mg} Q E / 100 \mathrm{~g}$ & $\begin{array}{l}\text { TEAC: } 2.86 \\
\text { ORAC: } 7.40\end{array}$ & n.i. & {$[51]$} \\
\hline & Italy & $\begin{array}{c}11.08 \mathrm{mg} \mathrm{GAE} / 100 \\
\mathrm{~g}\end{array}$ & $6.16 \mathrm{mg} Q E / 100 \mathrm{~g}$ & DPPH, I\% (\%): 73.04 & $\begin{array}{l}\uparrow \text { inhibition activity in MCF-7 cell line } \\
(159.4 \pm 3.6 \mu \mathrm{g} / \mathrm{mL})\end{array}$ & {$[68,174]$} \\
\hline $\begin{array}{l}\text { European goldenrod or } \\
\text { woundwort } \\
\text { Solidago virgaurea L) }\end{array}$ & Poland & $\begin{array}{l}11.29-21.03 \mathrm{mg} \\
\text { GAE } / 100 \mathrm{~g}\end{array}$ & $\begin{array}{l}0.93-1.41 \mathrm{mg} \\
\mathrm{QE} / 100 \mathrm{~g}\end{array}$ & $\begin{array}{l}\text { DPPH: } 31.08-39.46 \% \\
\text { ABTS: } 46.69-56-92 \%\end{array}$ & n.i. & [174] \\
\hline $\begin{array}{c}\text { Fennel honey } \\
\text { (Foeniculum vulgare) }\end{array}$ & Egypt & $\begin{array}{l}29.1-102.0 \mathrm{mg} \\
\text { GAE } / 100 \mathrm{~g}\end{array}$ & $\begin{array}{l}17.7-27.0 \mathrm{mg} \\
\mathrm{QE} / 100 \mathrm{~g}\end{array}$ & $\begin{array}{l}\text { Cellular antioxidant } \\
\text { activity: } 5.66-26.4 \mu \mathrm{mol} \\
\text { of } \mathrm{QE} / 100 \mathrm{~g}\end{array}$ & $\begin{array}{c}\leftrightarrow \text { inhibitory activity in MCF-7 (45.93\%) } \\
\downarrow \text { inhibitory activity in Caco-2 (25.53\%) and } \\
\text { Hep-G2 (11.75\%) }\end{array}$ & {$[168,175]$} \\
\hline $\begin{array}{l}\text { Gelam honey } \\
\text { (Kompassia eroxi) }\end{array}$ & Malaysia & $\begin{array}{c}74.12 \mathrm{mg} \mathrm{GAE} / 100 \\
\mathrm{~g}\end{array}$ & $46.11 \mathrm{mg}$ QE/100 g & $\begin{array}{c}\text { DPPH IC }_{50}(6.68 \pm 0.28) \\
\mathrm{mg} / \mathrm{mL} \\
\text { FRAP: } 115.61 \pm 3.86 \\
\mu \mathrm{mol} \text { Fe }[\mathrm{II}] / 100 \mathrm{~g}\end{array}$ & $\begin{array}{c}\uparrow \text { Antioxidant enzyme activities } \\
\downarrow \text { Hypertriglyceridemia and pro-oxidative } \\
\text { effects } \\
\uparrow \text { apoptosis in HepG2 cells at 3\% } \\
\text { concentration after } 24 \mathrm{~h} \\
\uparrow \text { apoptosis in WRL-68 cells at } 6 \% \text { after } 24 \mathrm{~h} \\
\downarrow \text { MDA levels in HIT-T15 cells } \\
\uparrow \text { insulin content }\end{array}$ & {$[176,177]$} \\
\hline $\begin{array}{l}\text { Goldenrod honey } \\
\quad \text { (Solidago sp.) }\end{array}$ & Poland & $\begin{array}{l}173.4 \mathrm{mg} \mathrm{GAE} / 100 \\
\mathrm{~g}\end{array}$ & n.a. & $\begin{array}{l}\text { DPPH: }(\mathrm{mmol} \\
\text { TEAC/kg): } 0.2 \\
\text { FRAP: }(\mathrm{mmol} \mathrm{Fe}(\mathrm{II}) / \mathrm{Kg} \\
\text { honey): } 1.0\end{array}$ & n.i. & [87] \\
\hline
\end{tabular}


Table 5. Cont.

\begin{tabular}{|c|c|c|c|c|c|c|}
\hline Honey Type & Origin & $\begin{array}{l}\text { TPC (mg GAE/100 } \\
\text { g) }\end{array}$ & $\begin{array}{c}\text { TFC (mg QE/100 } \\
\text { g) }\end{array}$ & Antioxidant Activity & In Vitro Pharmacological Activity & Reference \\
\hline \multirow[t]{2}{*}{$\begin{array}{c}\text { Heather honey (Calluna } \\
\text { vulgaris) }\end{array}$} & Portugal & $\begin{array}{l}117.59 \mathrm{mg} \\
\mathrm{GAE} / 100 \mathrm{~g}\end{array}$ & $21.16 \mathrm{mg} Q E / 100 \mathrm{~g}$ & $\begin{array}{l}\text { TEAC: } 0.86 \\
\text { ORAC: } 22.58\end{array}$ & $\begin{array}{c}\uparrow \text { apoptosis in HL-60 cells with } 50 \mathrm{mg} / \mathrm{mL} \\
\text { concentration of heather honey for } 48 \mathrm{~h} \\
\text { (70.4-78.5\%) } \\
\uparrow \text { antiproliferative activity } 72 \mathrm{~h} \text { treatment } \\
\text { with } 100-250 \mathrm{mg} / \mathrm{mL} \text { of heather honey } \\
(11.9-7.1 \% \text { of survival) } \\
\downarrow \text { ROS levels after } 24 \mathrm{~h} \\
\downarrow \text { DNA strand breaks }\left(0.1 \mathrm{mg} \mathrm{mL} \mathrm{mL}^{-1}, 15 \%\right) \\
\text { induced by BaP in HepG2 cells }\end{array}$ & {$[100,178,179]$} \\
\hline & Poland, Portugal & $\begin{array}{c}306.2-269.03 \mathrm{mg} \\
\mathrm{GAE} / \mathrm{kg}\end{array}$ & n.a. & $\begin{array}{c}\text { DPPH IC }_{50} \text { : (24.6 (SD } \\
0.2) \mathrm{mg} / \mathrm{mL}, \mathrm{FRAP}(1948 \\
\mathrm{mg} / \mathrm{kg} \\
\text { TEAC } / \mathrm{kg}): 0.6 \\
\text { FRAP: (mmol Fe(II)/Kg } \\
\text { honey): } 2.1\end{array}$ & $\begin{array}{c}\text { Protection of HepG2 against } \\
\text { mutagens-induced DNA damage }\end{array}$ & [87] \\
\hline $\begin{array}{l}\text { Lavander honey } \\
\text { (Lavandula sp.) }\end{array}$ & Portugal & $\begin{array}{l}31.85-34.13 \mathrm{mg} \\
\text { GAE/100 g }\end{array}$ & $\begin{array}{l}3.09-3.15 \mathrm{mg} \\
\mathrm{QE} / 100 \mathrm{~g}\end{array}$ & $\begin{array}{c}\text { DPPH IC }_{50}: 5.3 \mathrm{mg} / \mathrm{mL} \\
\text { TEAC: } 3.98-4.03 \\
\text { ORAC: } 7.43-7.57\end{array}$ & $\begin{array}{c}\text { Diabetic foot ulcers healing activity } \\
\text { through reducing ROS }\end{array}$ & {$[44,100]$} \\
\hline $\begin{array}{l}\text { Linden honey } \\
\quad \text { (Tilia } s p .)\end{array}$ & $\begin{array}{l}\text { Romania, } \\
\text { Slovenia, Poland }\end{array}$ & $\begin{array}{c}16.0-85.8 \mathrm{mg} \\
\mathrm{GAE} / \mathrm{kg} \\
192.5 \mathrm{mg} \mathrm{GAE} / 100 \\
\mathrm{~g}\end{array}$ & $\begin{array}{l}4.70-6.98 \mathrm{mg} \\
\mathrm{QE} / 100 \mathrm{~g}\end{array}$ & $\begin{array}{c}\text { DPPH IC } 50: 42.77 \\
\text { mg/mL, FRAP: } 137.8 \\
\text { mg/kg } \\
\text { DPPH: (mmol } \\
\text { TEAC/kg): } 0.4 \\
\text { FRAP: (mmol Fe(II)/Kg } \\
\text { honey): } 1.4\end{array}$ & $\downarrow$ Oxidative stress and ROS & {$[27,87,180]$} \\
\hline \multirow{2}{*}{$\begin{array}{l}\text { Manuka honey } \\
\text { Leptospermum scoparium } \\
\text { J.R. et G.Forst }\end{array}$} & \multirow[t]{2}{*}{ New Zealand } & 1288.0 GAE $\mu \mathrm{g} / \mathrm{g}$ & $37.64 \mathrm{CE} \mu \mathrm{g} / \mathrm{g}$ & $\begin{array}{c}\text { DPPH: } 18.69 \mu \mathrm{mol} \mathrm{TE} / \mathrm{g} \\
\text { FRAP: } 3.68 \mu \mathrm{mol} \mathrm{TE} / \mathrm{g} ; \\
\text { TEAC: } 30.72 \mu \mathrm{mol} \mathrm{TE} / \mathrm{g}\end{array}$ & $\begin{array}{c}\uparrow \text { GPx, } \downarrow \text { CAT activity, } \downarrow \text { DNA damage and } \\
\text { MDA level, protects proteins and lipids } \\
\text { against AAHP-induced stress }\end{array}$ & {$[159,181,182]$} \\
\hline & & $\begin{array}{l}429.61 \mathrm{mg} \text { GAE } \\
/ \mathrm{kg}\end{array}$ & $97.62 \mathrm{CE} \mathrm{mg} / \mathrm{kg}$ & $\begin{array}{c}\text { DPPH: } 0.06 \mathrm{mmol} \text { TE/ } \\
100 \mathrm{~g} \\
\text { FRAP: } 0.14 \mathrm{mmol} \text { TE/ } \\
100 \mathrm{~g} \text { TEAC: } 0.22 \mathrm{mmol} \\
\text { TE } / 100 \mathrm{~g}\end{array}$ & $\begin{array}{c}\downarrow \text { viability of B16 F1 cells ( } 0.3 \% \text { manuka) } \\
\text { after } 24 \mathrm{~h} \\
\uparrow \text { apoptosis in CT26 and MCF-7 cells with } \\
2.5 \% \text { manuka }\end{array}$ & {$[129,130,182]$} \\
\hline
\end{tabular}


Table 5. Cont.

\begin{tabular}{|c|c|c|c|c|c|c|}
\hline Honey Type & Origin & $\begin{array}{c}\text { TPC (mg GAE/100 } \\
\text { g) }\end{array}$ & $\begin{array}{c}\text { TFC (mg QE/100 } \\
\text { g) }\end{array}$ & Antioxidant Activity & In Vitro Pharmacological Activity & Reference \\
\hline $\begin{array}{l}\text { Oak honey } \\
\text { (Quercus sp.) }\end{array}$ & Turkey & $\begin{array}{l}115.41 \mathrm{mg} \\
\mathrm{GAE} / 100 \mathrm{~g}\end{array}$ & $77.36 \mathrm{mg} \mathrm{QE} / 100 \mathrm{~g}$ & $\begin{array}{l}\text { Inhibition of ABTS \%: } \\
89.36\end{array}$ & $\begin{array}{c}50 \% \text { inhibition after } 24 \mathrm{~h} \text { incubation of AGS } \\
\text { cells with the } 1.7 \% \text { final concentration } \\
\downarrow \text { ROS generation at the concentration of } \\
0.25 \%(w / v) \text { in AGS cells } \\
\text { DNA damage }\end{array}$ & [183] \\
\hline $\begin{array}{l}\text { Pine honey } \\
\text { (Pinus sp.) }\end{array}$ & $\begin{array}{l}\text { Greece, } \\
\text { Turkey }\end{array}$ & $\begin{array}{c}61.42-163.98 \mathrm{mg} \\
\mathrm{GAE} / 100 \mathrm{~g}\end{array}$ & $22.80 \mathrm{mg} \mathrm{QE} / 100 \mathrm{~g}$ & $\begin{array}{l}\text { DPPH: } 44.30 \\
\text { FRAP: } 1.48\end{array}$ & $\begin{array}{l}\downarrow \text { SOD and LPO, } \downarrow \text { CAT, GPx, GSH in liver } \\
\leftrightarrow \text { viability on Ishikawa and PC- } 3 \text { cells and } \\
\uparrow \text { viability of MCF- } 7 \text { cells } \\
\text { at } 0.2-125 \mu \mathrm{g} / \mathrm{mL} \text { concentration and } \\
\text { incubation for } 48 \text { hrs } \\
\text { mg cytotoxicity on MDAMB } 231 \text { cells with a } 1 \\
\text { mg dose } \\
\begin{array}{c}\text { cytotoxicity on MCF-7 and SKBR3 cancer } \\
\text { cell lines with a } 2.5-5 \mathrm{mg} / \mathrm{mL} \text { dose }\end{array}\end{array}$ & {$[25,108-110,166]$} \\
\hline $\begin{array}{c}\text { Pineapple } \\
\text { (Ananas comosus) }\end{array}$ & Malaysia & $\begin{array}{c}27.75 \mathrm{mg} \mathrm{GAE} / 100 \\
\mathrm{~g}\end{array}$ & $\begin{array}{l}24.74 \pm 0.35 \mathrm{mg} \\
\mathrm{QE} / 100 \mathrm{~g}\end{array}$ & $\begin{array}{c}\text { DPPH: } 10.86\left(\mathrm{IC}_{50} \text { values }\right. \\
\mathrm{mg} / \mathrm{mL}) \\
\text { FRAP }(\mu \mathrm{mol} \mathrm{Fe}[\mathrm{II}] / 100 \\
\text { g): } 47.92 \\
\text { Total antioxidant } \\
\text { capacity }(\mathrm{mg} \mathrm{AAE} / \mathrm{g}): \\
16.12\end{array}$ & $\begin{array}{c}\downarrow \text { lipid droplet size between } 33.78 \% \text { and } \\
\text { 70.36\% } \\
\downarrow \text { lipid accumulation compared to control } \\
\text { in 3T3-L1 murine pre-adipocytes }\end{array}$ & {$[176,184]$} \\
\hline $\begin{array}{l}\text { Rhododendron honey } \\
\text { (Rhododendron sp.) }\end{array}$ & Turkey & $\begin{array}{l}408.35 \mathrm{mg} \\
\mathrm{GAE} / 100 \mathrm{~g}\end{array}$ & & $\begin{array}{l}\text { DPPH: } 48.95 \mathrm{mg} / \mathrm{mL} \\
\text { FRAP: } 0.0077 \mathrm{mg} / 100 \mathrm{~g} \\
\text { honey }\end{array}$ & & [24] \\
\hline $\begin{array}{c}\text { Rosemary honey } \\
\text { (Rosmarinus officinalis L.) }\end{array}$ & Spain & $\begin{array}{l}102-118 \mathrm{mg} \\
\mathrm{GAE} / 100 \mathrm{~g}\end{array}$ & $\begin{array}{l}2.29-5.85 \mathrm{mg} \\
\mathrm{CE} / 100 \mathrm{~g}\end{array}$ & $\begin{array}{l}\text { DPPH: } 202 \mu \mathrm{mol} \mathrm{TE} / 100 \\
\text { g FRAP: } 215 \mu \mathrm{mol} \\
\text { TE } / 100 \mathrm{~g}\end{array}$ & $\begin{array}{l}\uparrow \text { apoptosis in HL-60 cells through a } \\
\text { ROS-independent cell death pathway } \\
\downarrow \text { DNA strand breaks }\left(0.1-10 \mathrm{mg} \mathrm{mL}^{-1}\right. \\
\text { 19-25\%) induced by BaP in HepG2 cells }\end{array}$ & {$[179,185]$} \\
\hline
\end{tabular}


Table 5. Cont.

\begin{tabular}{|c|c|c|c|c|c|c|}
\hline Honey Type & Origin & $\begin{array}{l}\text { TPC (mg GAE/100 } \\
\text { g) }\end{array}$ & $\begin{array}{c}\text { TFC (mg QE/100 } \\
\text { g) }\end{array}$ & Antioxidant Activity & In Vitro Pharmacological Activity & Reference \\
\hline $\begin{array}{c}\text { Savory honey } \\
\text { (Satureja montana L.) }\end{array}$ & Italy & $\begin{array}{l}253.78 \mathrm{mg} \\
\mathrm{GAE} / 100 \mathrm{~g}\end{array}$ & $\begin{array}{c}211.68 \mathrm{mg} \mathrm{QE} / 100 \\
\mathrm{~g}\end{array}$ & $\begin{array}{c}\text { DPPH, } \mathrm{IC}_{50}(\mathrm{mg} / \mathrm{mL}): \\
10.85 \\
\text { FRAP: }(\mathrm{mmol} \mathrm{Fe}(\mathrm{II}) / \mathrm{Kg}: \\
3.702\end{array}$ & $\begin{array}{c}\leftrightarrow \text { inhibition activity in } \mathrm{BJ}\left(\mathrm{IC}_{50}=\right. \\
27.25-29.70 \mathrm{mg} / \mathrm{mL}) \\
\uparrow \text { inhibition activity in MCF-7 }\left(\mathrm{IC}_{50}=\right. \\
22.85-44.60 \mathrm{mg} / \mathrm{mL}), \mathrm{HeLa}\left(\mathrm{IC}_{50}=26.70-\right. \\
44.20 \mathrm{mg} / \mathrm{mL}) \text { and in SW620 }(25.50-49.70 \\
\mathrm{mg} / \mathrm{mL}) \\
\text { apoptosis in SW620 after } 48 \mathrm{~h} \text { with savory } \\
\text { honey }() \\
\leftrightarrow \text { apoptosis in MCF-7 and HeLa after } 48 \mathrm{~h}\end{array}$ & [186] \\
\hline \multirow[t]{2}{*}{$\begin{array}{l}\text { Strawberry tree honey } \\
\quad \text { (Arbutus unedo) }\end{array}$} & Italy & & & $\begin{array}{c}\text { DPPH: } 200.83(\mu \mathrm{mol} \\
\text { TE } / 100 \mathrm{~g}) \\
\text { FRAP: } 539.01 \mu \mathrm{mol} \\
\text { TE } / 100 \mathrm{~g} \\
\text { TEAC: } 392.13 \mu \mathrm{mol} \\
\text { TE } / 100 \mathrm{~g}\end{array}$ & $\begin{array}{c}\downarrow \text { NF- } \mathrm{B}, \mathrm{p} \text {-I } \mathrm{I} B \alpha \text { and Nrf2 expression, } \downarrow \\
\text { mitochondrial respiration and glycolysis } \\
\uparrow \text { apoptosis in human colon } \\
\text { adenocarcinoma (HCT-116) and metastatic } \\
\quad \text { (LoVo) cancer cells } \\
\downarrow \text { Cell viability } \uparrow \text { ROS generation } \downarrow \\
\text { Antioxidant enzyme activity } \downarrow \text { Nrf2, SOD, } \\
\text { catalase, HO- } 1 \uparrow \text { Lipid peroxidation and } \\
\text { protein carbonyl content in HCT-116 and } \\
\text { LoVo colon cancer cells at 3-12 and 10-40 } \\
\text { mg/mL for } 48 \mathrm{~h} \\
\uparrow \text { p53, caspase-3, -8, -9, c-PARP1, Bax, Cyto } \\
\text { C, FasL } \downarrow \text { Bcl in HCT-116 and LoVo colon } \\
\text { cancer cells at 3-12 and 10-40 mg/mL for } \\
48 \mathrm{~h}\end{array}$ & {$[187,188]$} \\
\hline & Portugal & 91.74-117.65 & $\begin{array}{l}4.09-9.66 \mathrm{mg} \\
\mathrm{QE} / 100 \mathrm{~g}\end{array}$ & $\begin{array}{c}\text { DPPH: } 40.28-45.20 \% \\
\text { TEAC:0.39-0.44 mmol } \\
\text { TE } / 100 \mathrm{~g} \\
\text { ORAC:39.55 }\end{array}$ & n.i. & {$[100,189]$} \\
\hline \multirow[t]{2}{*}{$\begin{array}{l}\text { Sulla honey (Hedysarum } \\
\text { sp.) }\end{array}$} & Italy & $\begin{array}{c}60.50 \mathrm{mg} \mathrm{GAE} / 100 \\
\mathrm{~g}\end{array}$ & $41.88 \mathrm{mg} \mathrm{QE} / 100 \mathrm{~g}$ & $\begin{array}{c}\text { DPPH, } \mathrm{IC}_{50}(\mathrm{mg} / \mathrm{mL}): \\
54.74 \\
\text { FRAP, (mmol Fe(II)/Kg): } \\
1.299\end{array}$ & n.i. & {$[79,94]$} \\
\hline & Italy & $\begin{array}{c}11.26 \mathrm{mg} \mathrm{GAE} / 100 \\
\mathrm{~g}\end{array}$ & $6.76 \mathrm{mg} Q E / 100 \mathrm{~g}$ & DPPH, I\%: 66.60 & n.i. & [68] \\
\hline
\end{tabular}


Table 5. Cont

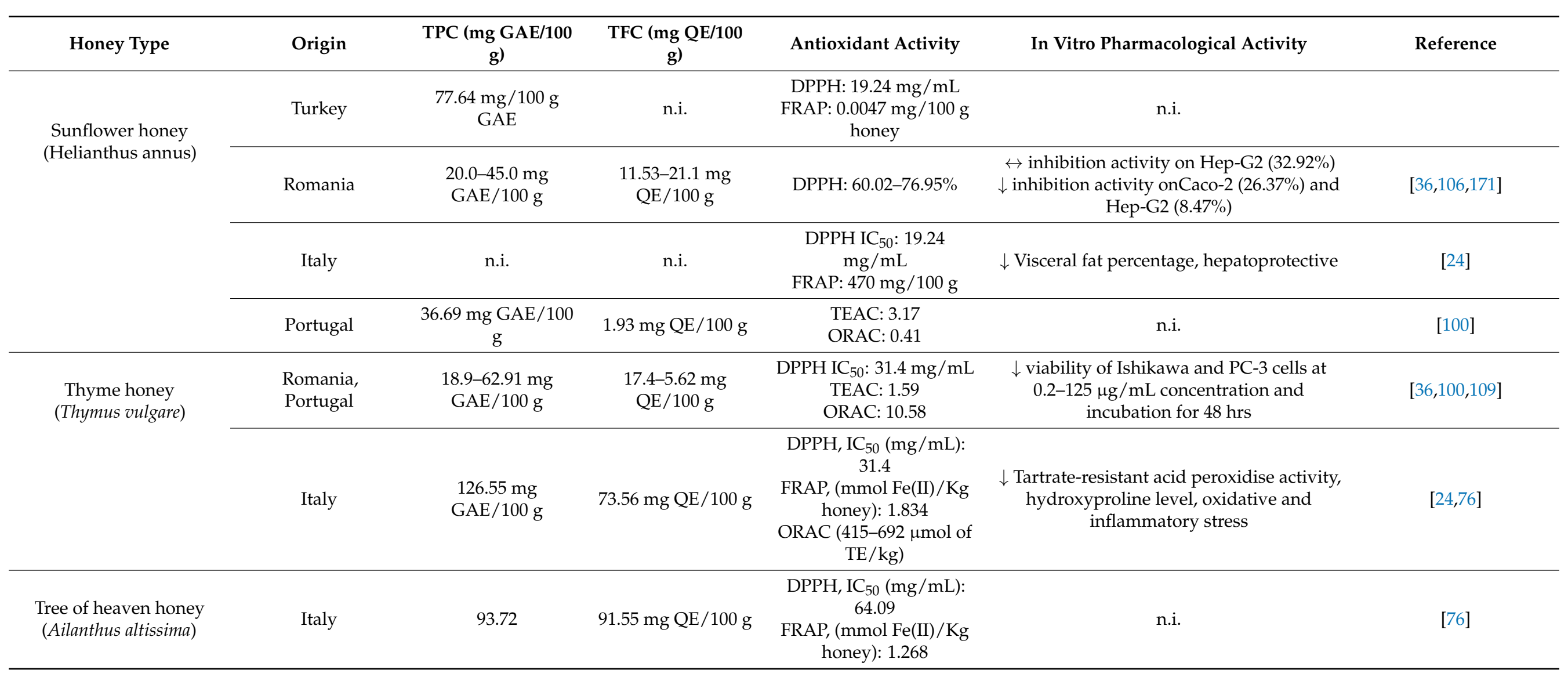


Table 5. Cont.

\begin{tabular}{|c|c|c|c|c|c|c|}
\hline Honey Type & Origin & $\begin{array}{c}\text { TPC (mg GAE/100 } \\
\text { g) }\end{array}$ & $\begin{array}{c}\text { TFC (mg QE/100 } \\
\text { g) }\end{array}$ & Antioxidant Activity & In Vitro Pharmacological Activity & Reference \\
\hline $\begin{array}{l}\text { Tualang honey } \\
\text { (Koompassia excels) }\end{array}$ & Malaysia & $\begin{array}{c}83.96 \mathrm{mg} \mathrm{GAE} / 100 \\
\mathrm{~g}\end{array}$ & $50.45 \mathrm{mg} \mathrm{QE} / 100 \mathrm{~g}$ & $\begin{array}{c}\text { DPPH: } 9.65 \mathrm{mg} \\
\text { AAE/100 g } \\
\text { FRAP: } 52.39 \mathrm{mg} \text { TE/ } 100 \\
\mathrm{~g}\end{array}$ & $\begin{array}{c}\uparrow \text { apoptosis }(51.2 \%) \text { at } 48 \mathrm{~h} \text { for } \\
\text { MDA-MB- } 231 \text { cells } \\
\text { cells at } 72 \mathrm{~h} \\
\uparrow \text { apoptosis } 55.6 \% \text { MCF- } 56.2 \% \text {, HeLa } \\
\downarrow \text { mitochondrial membrane potential }\left(\Delta \psi_{\mathrm{m}}\right) \\
\text { in the cancer cell lines after } 24 \mathrm{~h} \text { of } \\
\text { treatment } \\
\uparrow \text { apoptosis }(42.8 \%) \text { in MCF-7 cells after } 24 \\
\mathrm{~h} \\
\downarrow \text { Lipid hydroperoxides, } \downarrow \text { MDA, } \downarrow \\
\text { pancreatic SOD, } \uparrow \text { pancreatic CAT } \\
\text { apoptotic cell death in OSCC and HOS cell } \\
\text { lines when treated with } 2 \% \text { and } 10 \% \text { honey } \\
\text { for } 24,48 \text { and } 72 \mathrm{~h}\end{array}$ & [190-193] \\
\hline $\begin{array}{l}\text { Willow honey } \\
\quad(\text { Salix } s p .)\end{array}$ & Poland & $288.0 \mathrm{mg} \mathrm{GAE} / \mathrm{kg}$ & n.i. & $\begin{array}{c}\text { DPPH, }(\mathrm{mmol} \\
\text { TEAC } / \mathrm{kg}): 2.1 \\
\text { FRAP, }(\mathrm{mmol} \mathrm{Fe}(\mathrm{II}) / \mathrm{Kg}): \\
0.5\end{array}$ & n.i. & [94] \\
\hline $\begin{array}{l}\text { Ziziphus honey } \\
\text { (Ziziphus sp.) }\end{array}$ & Egypt, Sudan & $\begin{array}{c}81.37-96.99 \mathrm{mg} \\
\text { GAE } / 100 \mathrm{~g}\end{array}$ & $\begin{array}{c}5.43-9.15 \mathrm{mg} \\
\mathrm{QE} / 100 \mathrm{~g}\end{array}$ & $\begin{array}{c}\text { DPPH: } 32.70-86.18 \% \\
\left.\text { ABTS (IC } \mathrm{IC}_{50}=\mathrm{mg} / \mathrm{mL}\right) \\
3.60\end{array}$ & $\begin{array}{c}\leftrightarrow \text { inhibitory activity in Caco-2 (34.22\%) } \\
\downarrow \text { inhibitory activity in MCF-7 (29.87\%) and } \\
\text { Hep-G2 (15.94\%) }\end{array}$ & {$[168,194]$} \\
\hline
\end{tabular}

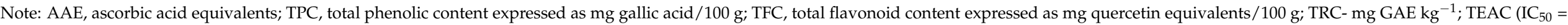

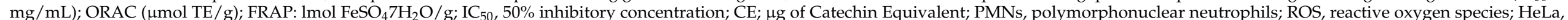

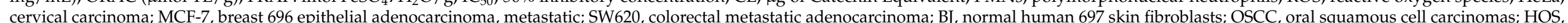
human osteosarcoma;n.i., not identified; $\uparrow$ high/increase; $\downarrow$ low/decrease; $\leftrightarrow$ moderate/medium. 
As can be seen, the Portuguese honeys' TPC (mg GAE/100 g) varies from 31.85 in Lavender to 117.65 in Strawberry tree and Heather honeys. The flavonoid content $(\mathrm{mg}$ of $\mathrm{QE} / 100 \mathrm{~g}$ ) ranges between 1.93 in Sunflower to 21.16 in Heather honey. In the study performed by Rosa and his collaborators (2011) [195], it was found that Strawberry tree honey had the highest TPC, as well as higher activity in the DPPH and FRAP tests, compared to Citrus, Heather and Eucalyptus honeys. Furthermore, from the total phenols content, homogentisic acid (i.e., the chemical marker for strawberry tree honey) was more than $60 \%$ and showed significant antioxidant and antiradical activities, as well as a protective effect against thermal cholesterol degradation. Wang et al. (2019) [196] determined the TPC and TFC from Prunella vulgaris (PVH) monofloral honey, a known traditional Chinese medicine, which displayed a TPC of $145.7 \mathrm{mg}$ chlorogenic acid equivalent (CAE) $/ \mathrm{kg}$ and a TFC of $10.0 \mathrm{mg}$ QE $/ \mathrm{kg}$. The TFC of PVH was higher compared to other monofloral honeys with potential medicinal value, such as Acacia, Buckwheat and Manuka, but lower compared to Heather, Sunflower, Canola, Pine, and Thyme. Additionally, the TFC was relatively high compared to Rhododendron and Chestnut from Turkey and coffee honey from Brazil. Furthermore, low TPC in the Rhododendron honey was noticed in the samples from Ordu and Artvin, whereas the samples from Zonguldak and Kastamonu exhibited the highest TPC compared to the other regions. Therefore, the TPC is strongly correlated to the antioxidant activity, as demonstrated in multiple studies. In the study conducted by Socha et al., 2011 [197], the TPC in Polish honeys was much lower (4.46-15.04 mg GAE/100 g), especially in Buckwheat honey (15.04 mg GAE/100 g).

Kus et al., 2014b [87] evaluated the TPC and antioxidant activities of several polish honeys. Their results showed that the TPC ranged between 121.6-1173.8 mg GAE $/ \mathrm{kg}$. Similar phenolic contents were reported for Mexican honeys (283.9-1142.9 mg GAE/ kg), from which the highest TP content was found in multifloral, orange blossom and bell flower samples [198]. Furthermore, TPC was found to be similar in Burkina Fasan honeys (325.9-1147.5 mg GAE/ kg), with the richest content in honeydew and Vitellaria honeys [154]. In the study conducted by Anand et al., 2018 [159], the lowest TPC was recorded for Agastache honey (853.6 $\pm 5 \mu \mathrm{g} \mathrm{GAE} / \mathrm{g}$ ) and the highest for Jelly bush honey $1415.6 \pm 126 \mu \mathrm{g}$ GAE/g). Jelly bush honey contained the highest TFC $(53.9 \pm 10.9 \mu \mathrm{g}$ $\mathrm{CE} / \mathrm{g})$, whereas Tea-tree honey had the lowest TFC $(20 \pm 4.3 \mu \mathrm{g} C E / g)$. The scavenging activity of free radicals determined by DPPH assay indicated that the highest antioxidant activity was present in Manuka honey (18.69 $\pm 0.9 \mu \mathrm{mol} \mathrm{TE} / \mathrm{g}$ ) followed by Jelly bush and Tea-tree. Similarly, the scavenging activity of free radicals determined by TEAC assay indicated that the highest activity was shown in Manuka honey $(30.72 \pm 0.27 \mu \mathrm{mol} \mathrm{TE} / \mathrm{g})$, followed by Agastache and Jelly bush.

Multiple studies have demonstrated the potential therapeutic properties of monofloral honeys due to their bioactive compounds, as well as based on their geographical origin. Further details can be seen in Table 5.

In the last decade, monofloral honeys have attracted great interest from researchers. For the first time, the phytochemical composition of several significant monofloral Cuban honeys and their relationships with the biological activities were studied by AlvarezSuarez et al. Their antioxidant [199] and antimicrobial [200] properties were evaluated and discussed also in terms of correlation with amino acids, proteins, carotenoids, colour, TPC and TFC. The analysed samples possessed important antioxidant and antibacterial properties, as well as high concentrations of phenolic acids, flavonoids and carotenoids. Later, Alvarez-Suarez et al., 2012 [66] showed that Cuban honeys ether-soluble phenolic fraction exhibits significant radical scavenging activity and protection of RBCs against hemolysis and lipid peroxidation induced by free radicals, as well as protection against depletion of SOD and GSH enzymes.

In the study conducted by Park et al. 2020 [119], the antioxidant activity of Hovenia honey was evaluated. Their study showed that the Hovenia honeys had a significantly $(p<0.05)$ higher DPPH radical scavenger activity $(36.3-38.7 \mu \mathrm{mol}$ TE/100 g honey) and a similar ABTS radical scavenger activity (129.5-141.9 $\mu \mathrm{mol}$ TE/100 g honey), compared 
to Acacia honey (ABTS: 13.9-22.4 $\mu \mathrm{mol} \mathrm{TE} / 100 \mathrm{~g}$ honey and DPPH: $130.6 \pm 6.74 \mu \mathrm{mol}$ $\mathrm{TE} / 100 \mathrm{~g}$ honey). Interestingly, the amounts of TPC and TFC were not significantly different between these honey types.

These findings suggest that beside floral origin, the provenance is also significant for the phenols content of honeys from the same species.

\section{Health Effects of Monofloral Honeys}

Honey has been widely used as a folk medicine, being acknowledged centuries ago [201,202]. Hippocrates emphasized the similarity of honey to air and water, that honey is a very valuable antidote and that it can be used alone or mixed with herbs in the form of sherbet, ointment, and drug in the treatment of many physical and mental illnesses [203]. With the widespread use of apitherapy in recent years, the use of bee products and honey has increased [204]. In Table 6, several in vivo studies on animal models and human subjects are summarized based on honey types, antioxidant, anti-diabetic, anticancer and wound healing properties.

Table 6. In vivo studies of different monofloral honey types.

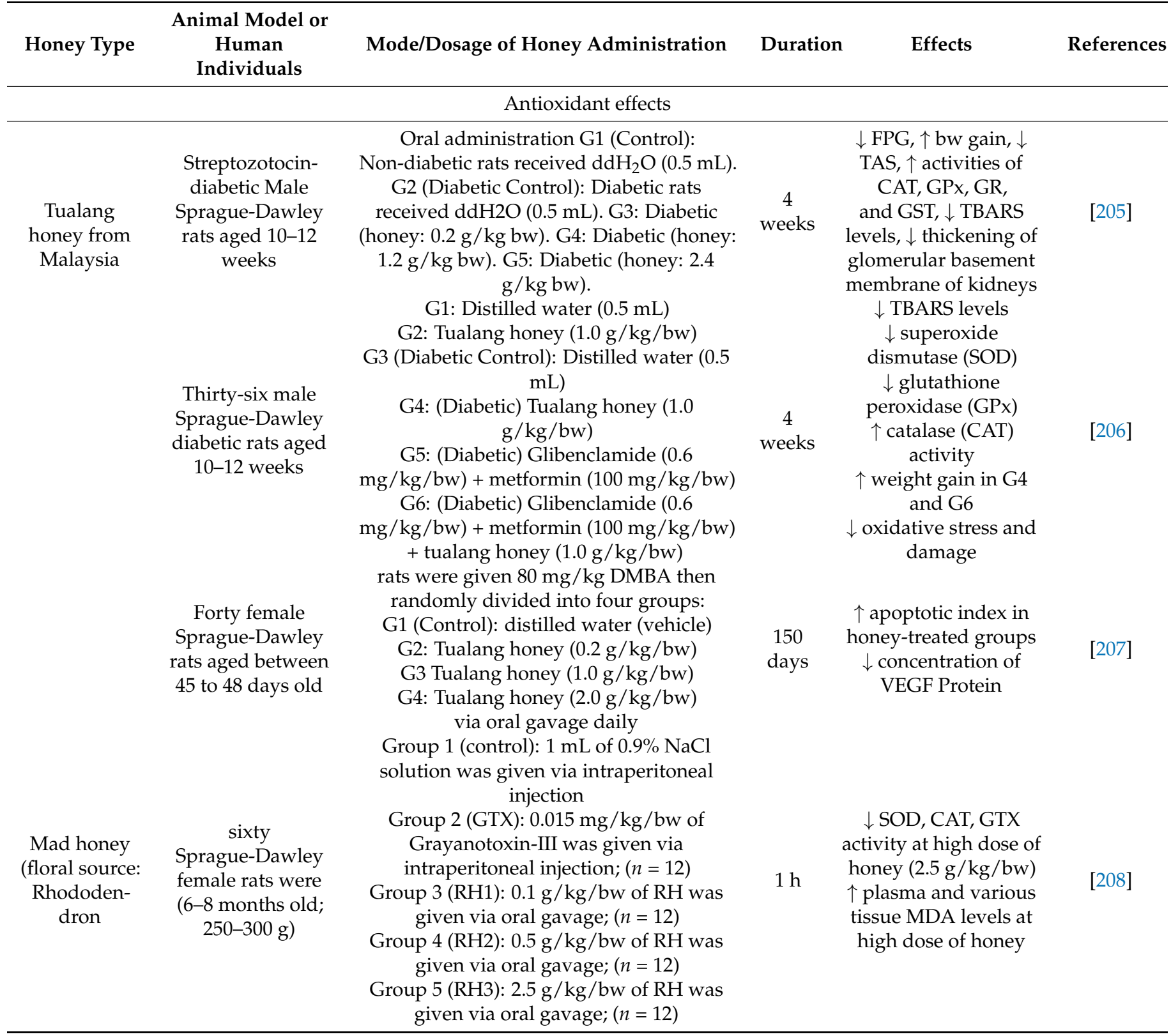


Table 6. Cont.

\begin{tabular}{|c|c|c|c|c|c|}
\hline Honey Type & $\begin{array}{l}\text { Animal Model or } \\
\text { Human } \\
\text { Individuals }\end{array}$ & Mode/Dosage of Honey Administration & Duration & Effects & References \\
\hline $\begin{array}{l}\text { Pine honey } \\
\text { from Turkey }\end{array}$ & $\begin{array}{l}\text { Forty-eight male } \\
\text { BALB/c mice, } \\
\text { weighing 30-35 g }\end{array}$ & $\begin{array}{c}\text { G1: control } \\
\text { G2: } 1 \mathrm{~g} / \mathrm{kg} \text { bw } / \text { day pine honey } \\
\text { G3: } 180 \mathrm{mg} / \mathrm{kg} \text { bw } / \text { day }\left(\sim 1 / 5 \mathrm{LD}_{50}\right) \\
\text { trichlorfon } \\
\text { G4: } 180 \mathrm{mg} / \mathrm{kg} \text { bw/day trichlorfon plus } 1 \\
\mathrm{~g} / \mathrm{kg} \mathrm{bw} / \text { day pine honey }\end{array}$ & \multicolumn{2}{|r|}{$\begin{array}{l}\downarrow \text { MDA levels, } \uparrow \text { SOD } \\
\text { levels, } \leftrightarrow \text { CAT and } \\
\text { GSH-Px levels in G2 } \\
\text { and G4 in liver, kidney, } \\
\text { heart and brain tissues }\end{array}$} & [209] \\
\hline $\begin{array}{l}\text { Malicia } \\
\text { honey } \\
\text { (Mimosa } \\
\text { quadrivalvis } \\
\text { L) }\end{array}$ & $\begin{array}{l}\text { Thirty-two male } \\
\text { Wistar rats at } 90 \\
\text { days of age }\end{array}$ & $\begin{array}{l}\text { G1 (control): saline solution via gavage } \\
\text { G2 (dyslipidaemic control): saline solution } \\
\text { via gavage + dyslipidaemic diet ( } 6 \% \text { lard, } \\
5 \% \text { non-hydrolysed vegetable fat, } 1 \% \\
\text { cholesterol and } 0.5 \% \text { cholic acid) } \\
\text { G3: honey via gavage } \\
\text { G4: honey via gavage + dyslipidaemic diet }\end{array}$ & $\begin{array}{c}5 \\
\text { weeks }\end{array}$ & $\begin{array}{c}\downarrow \text { Food consumption, } \\
\uparrow \text { glucose tolerance } \\
\text { and SOD activity } \\
\downarrow \text { TC, LDL and AST } \\
\text { levels } \\
\uparrow \text { beneficial bacteria } \\
\text { and organic acids } \\
\downarrow \text { tissue damage in } \\
\text { colon and liver } \\
\text { induced by the } \\
\text { dyslipidaemic diet } \\
\uparrow \text { GPX, SOD, }\end{array}$ & [210] \\
\hline Fennel honey & $\begin{array}{l}\text { Eight female goats } \\
\text { s } 4-5 \text { months old } \\
\text { weighing about } \\
10-24 \mathrm{~kg} \mathrm{bw}\end{array}$ & $\begin{array}{l}\text { Intravenous administration } 70-80 \\
\text { drops/min as rapid infusion of } 20 \% \text { honey } \\
\text { solution, daily }\end{array}$ & $\begin{array}{c}4 \\
\text { weeks }\end{array}$ & $\begin{array}{c}\text { Lymphocytes (\%), } \\
\text { Total Leucocytic count } \\
(\times 103 / \mu \mathrm{L}) \text {, Monocytes } \\
(\%) \\
\downarrow \text { MDA, Plasma } \\
\text { globulin }(\mathrm{g} / \mathrm{dL}), \\
\text { Ascorbic acids } \\
(\mathrm{mg} / \mathrm{dL}),\end{array}$ & [211] \\
\hline $\begin{array}{l}\text { Chestnut } \\
\text { honey }\end{array}$ & $\begin{array}{c}\text { Eighteen Male } \\
\text { Wistar rats } \\
\text { weighing } 150 \text { to } \\
175 \mathrm{~g}\end{array}$ & $\begin{array}{c}\text { G1: indomethacin }(60 \mathrm{mg} / \mathrm{kg} \text {, orally })+ \\
\text { honey } \\
\text { G2: indomethacin + Alimento Supervis } \\
\text { G3: indomethacin + Alimento } \\
\text { Mieleucalipto } \\
\text { G4: indomethacin + sucralfate } \\
\text { G5: tap water }(5 \mathrm{~mL} / \mathrm{kg})\end{array}$ & 7 days & $\begin{array}{c}\text { Prevention of } \\
\text { indomethacin- } \\
\text { induced gastric lesions } \\
\downarrow \text { ulcer index } \\
\downarrow \text { microvascular } \\
\text { permeability } \\
\downarrow \text { myeloperoxidase } \\
\text { activity of the stomach }\end{array}$ & [212] \\
\hline \multicolumn{6}{|c|}{ Weight control } \\
\hline Clover honey & $\begin{array}{l}\text { Thirty-six male } \\
\text { Sprague-Dawley } \\
\text { rats }(228.1 \pm 12.5 \\
\text { g) }\end{array}$ & $\begin{array}{l}\text { divided by weight into } 2 \text { groups }(n=18) \\
\text { and provided free access to } 1 \text { of } 2 \text { diets } \\
\text { ( } 20 \% \text { carbohydrate (by weight of total diet) } \\
\text { from either clover honey or sucrose) }\end{array}$ & $\begin{array}{c}33 \\
\text { days }\end{array}$ & $\begin{array}{l}\downarrow \text { Weight gain and } \\
\quad \text { adiposity, } \downarrow \text { TG } \\
\uparrow \text { non-HDL-C levels }\end{array}$ & [213] \\
\hline $\begin{array}{l}\text { Acacia and } \\
\text { Gelam honey }\end{array}$ & $\begin{array}{l}\text { Seven-week-old } \\
\text { male } \\
\text { Sprague-Dawley } \\
\text { rats, with body } \\
\text { weight ranging } \\
\text { from } 200 \text { to } 220 \mathrm{~g}\end{array}$ & $\begin{array}{c}\text { G1: normal control } \\
\text { G2: high fat diet } \\
\text { G3: high fat diet rats fed with Gelam honey, } \\
\text { G4: high fat diet rats fed with Acacia honey, } \\
\text { G5: high fat diet rats treated with orlistat }\end{array}$ & $\begin{array}{c}4 \\
\text { weeks }\end{array}$ & $\begin{array}{c}\downarrow \text { in excess weight gain } \\
\text { and adiposity index } \\
\downarrow \text { plasma glucose, } \\
\text { triglycerides, } \\
\text { and cholesterol, } \\
\text { plasma leptin and } \\
\text { resistin, liver enzymes, } \\
\text { renal function test, } \\
\text { and relative organ } \\
\text { weight }\end{array}$ & [214] \\
\hline $\begin{array}{c}\text { Honeydew } \\
\text { honey }\end{array}$ & $\begin{array}{l}\text { Fifty-five Sprague } \\
\text { Dawley rats, aged } \\
\text { approximately } 8 \\
\text { weeks }\end{array}$ & $\begin{array}{l}\text { G1: sugar-free diet } \\
\text { G2: } 7.9 \% \text { sucrose } \\
\text { G3: } 10 \% \text { honey }\end{array}$ & $\begin{array}{l}365 \\
\text { days }\end{array}$ & $\begin{array}{l}\text { Similar weight gain } \\
\text { and body fat in honey } \\
\text { and control group; } \\
\downarrow \text { HbA1c, } \uparrow \text { HDL-C }\end{array}$ & [215] \\
\hline
\end{tabular}


Table 6. Cont.

\begin{tabular}{|c|c|c|c|c|c|}
\hline Honey Type & $\begin{array}{c}\text { Animal Model or } \\
\text { Human } \\
\text { Individuals }\end{array}$ & Mode/Dosage of Honey Administration & Duration & Effects & References \\
\hline $\begin{array}{l}\text { Tualang } \\
\text { honey from } \\
\text { Malaysia }\end{array}$ & $\begin{array}{l}\text { male Wistar albino } \\
\text { rats }(n=40) \\
\text { weighing } \\
160-180 \mathrm{~g}\end{array}$ & $\begin{array}{c}\text { G1 (control): standard laboratory diet and } \\
\text { drinking water ad libitum } \\
\text { G2 (Tualang Honey): Orally administered } \\
\text { ( } 3 \mathrm{~g} / \mathrm{kg} \text { ) for } 45 \text { days. } \\
\text { G3 (ISO): Animals were subcutaneously } \\
\text { injected with ISO ( } 85 \mathrm{mg} / \mathrm{kg} \text { ) on the } 44 \text { th } \\
\text { and } 45 \text { th days (at an interval of } 24 \mathrm{~h}) \\
\text { G4 (TH + ISO): Animals were orally treated } \\
\text { with TH ( } 3 \mathrm{~g} / \mathrm{kg} \text { ) for a period of } 45 \text { days } \\
\text { followed by subcutaneous injection of ISO } \\
(85 \mathrm{mg} / \mathrm{kg} \text { ) on the } 44 \text { th and } 45 \text { th days (at } \\
\text { an interval of } 24 \mathrm{~h})\end{array}$ & 2 days & $\begin{array}{c}\uparrow \text { Antioxidant enzyme } \\
\text { levels in heart tissue } \\
\downarrow \text { LPO }\end{array}$ & [216] \\
\hline Pineapple & $\begin{array}{l}\text { Forty-eight healthy } \\
\text { Sprague Dawley } \\
\text { male rats } \\
\text { weighting 280-220 } \\
\text { g }\end{array}$ & $\begin{array}{l}\text { G1 (control): water ad libitum } \\
\text { G2: } 2000 \mathrm{mg} / \mathrm{kg} \text { bw pineapple honey for } \\
24 \mathrm{~h} \\
\text { G3: } 2000 \mathrm{mg} / \mathrm{kg} \text { bw adulterated honey A } \\
\text { G4: } 2000 \mathrm{mg} / \mathrm{kg} \text { bw adulterated honey B }\end{array}$ & $\begin{array}{c}14 \\
\text { days }\end{array}$ & $\begin{array}{c}\downarrow \text { cholesterol levels } \\
(18.94 \pm 3.6 \mathrm{mmol} / \mathrm{L}) \\
\downarrow \text { triglycerides }(13.5 \pm \\
1.5 \mathrm{mmol} / \mathrm{L}) \text { and } \\
\text { glucose }(8.0 \pm 1.5 \\
\text { mmol/L) levels } \\
\text { Early mortality in G3 } \\
\text { and G4 of five rats }\end{array}$ & [217] \\
\hline \multicolumn{6}{|c|}{ Hypercholesterolemia and anti-diabetic } \\
\hline $\begin{array}{l}\text { Mad honey } \\
\text { (floral source: } \\
\text { Rhododendron } \\
\text { ponticum) } \\
\text { from Turkey }\end{array}$ & $\begin{array}{l}\text { Streptozotocin- } \\
\text { diabetic rats and } \\
\text { non-diabetic rats }\end{array}$ & $\begin{array}{l}\text { Honey given } 50 \mathrm{mg} / \mathrm{kg} / \text { day }(2 \mathrm{~mL} \text { mad } \\
\text { honey dissolved in distilled water })\end{array}$ & 3 days & $\begin{array}{l}\text { Significant } \downarrow \text { Glucose in } \\
\text { both diabetic and } \\
\text { non-diabetic rats }\end{array}$ & [218] \\
\hline $\begin{array}{l}\text { Clover and } \\
\text { Citrus honey } \\
\text { from Egypt, } \\
\text { and Ziziphus } \\
\text { honey from } \\
\text { Yemen and } \\
\text { Pakistan }\end{array}$ & $\begin{array}{l}\text { Type } 2 \text { diabetics } \\
\text { human subjects }(n \\
=38)\end{array}$ & $\begin{array}{l}\text { Solely treated with honey } 2 \mathrm{~g} / \mathrm{kg} / \mathrm{day} \text {, } \\
\text { orally, before meals twice daily, no } \\
\text { antidiabetic medicines were running }\end{array}$ & $\begin{array}{l}\text { Between } \\
0.42- \\
13.5 \\
\text { years }\end{array}$ & $\begin{array}{c}\uparrow \text { Glucose, } \leftrightarrow \text { RBG, } \leftrightarrow \\
\text { TG, } \leftrightarrow \text { TC, } \leftrightarrow \text { HDL, } \leftrightarrow \\
\text { LDL, } \leftrightarrow \text { TC } / \text { HDL and } \\
\text { LDL/HDL ratios, } \downarrow \\
\text { SBP, } \downarrow \text { DBP, } \downarrow \text { bw, } \\
\text { prevented } \\
\text { ketoacidosis, } \\
\text { hyperglycaemic } \\
\text { hyperosmolar state, } \\
\text { and macrovascular } \\
\text { complications } \\
\text { (particularly coronary } \\
\text { heart disease) }\end{array}$ & [219] \\
\hline $\begin{array}{l}\text { Kanuka } \\
\text { honey }\end{array}$ & $\begin{array}{c}\text { Type } 2 \text { diabetes } \\
\text { human subject, } \\
\text { weight and blood } \\
\text { samples }\end{array}$ & $\begin{array}{l}\text { G1: } 53.5 \mathrm{~g} \text { (three tablespoons) of kanuka } \\
\text { honey } \\
\text { G2: mixture of a formulated honey }(53.5 \mathrm{~g} \text { ) } \\
\text { comprised of } 4.5 \mathrm{~g} \text { food grade cinnamon, } \\
200 \mu \mathrm{g} \text { chromium polynicotinate and } 120 \\
\text { mg magnesium citrate mixed with } 100 \% \\
\text { kanuka honey }\end{array}$ & $\begin{array}{c}40 \\
\text { days }\end{array}$ & $\begin{array}{c}\downarrow \text { weight } \\
\downarrow \text { blood pressure } \\
\downarrow \text { TC } \\
\text { Improve blood lipid } \\
\text { profile }\end{array}$ & [220] \\
\hline \multirow[t]{2}{*}{$\begin{array}{l}\text { Clover honey } \\
\text { from Egypt }\end{array}$} & $\begin{array}{l}\text { Type } 1 \text { diabetics } \\
\text { human subjects }(n \\
=20) \text { aged } 4-18 \\
\text { years }\end{array}$ & $\begin{array}{l}\text { Orally administered honey }(0.5 \mathrm{~mL} / \mathrm{kg} \\
\text { bw/day) }\end{array}$ & $\begin{array}{c}12 \\
\text { weeks }\end{array}$ & $\begin{array}{c}\downarrow \text { FSG }, \downarrow \text { Glycosylated } \\
\text { hemoglobin, } \downarrow \text { SSFT, } \downarrow \\
\text { TC, } \downarrow \text { LDL }, \uparrow \text { FCP }, \uparrow \\
\text { PCP }\end{array}$ & [221] \\
\hline & $\begin{array}{l}\text { Single case report of } \\
\text { a patient with CHD, } \\
\text { hypertension and } \\
\text { type } 2 \text { diabetes }\end{array}$ & Given $150 \mathrm{~g}$ honey daily, orally & $\begin{array}{c}11 \\
\text { years }\end{array}$ & $\begin{array}{l}\text { Controlled RBG, blood } \\
\text { pressure, } \\
\text { improved/stabilized } \\
\text { CHD, prevented } \\
\text { ketoacidosis or } \\
\text { hyperosmolar coma. }\end{array}$ & [222] \\
\hline
\end{tabular}


Table 6. Cont.

\begin{tabular}{|c|c|c|c|c|c|}
\hline Honey Type & $\begin{array}{l}\text { Animal Model or } \\
\text { Human } \\
\text { Individuals }\end{array}$ & Mode/Dosage of Honey Administration & Duration & Effects & References \\
\hline $\begin{array}{l}\text { Coriander } \\
\text { honey from } \\
\text { Egypt }\end{array}$ & $\begin{array}{c}210 \text { male Swiss } \\
\text { albino mice } \\
\text { weighting 22-25 g } \\
\text { with serial } \\
\text { intraperitoneal } \\
\text { passage } \\
\text { Ehrlich ascites } \\
\text { carcinoma cells }\end{array}$ & $\begin{array}{c}\text { G1 (normal control): orally dose of } 50 \mu \mathrm{l} / \\
\text { mouse normal saline daily } \\
\text { G2 (coriander control): daily dose of } 500 \\
\text { mg/ } / \mathrm{kg} / \text { mouse through oral } \\
\text { administration } \\
\text { G3 (5-FU control): daily dose of } 20 \\
\text { mg/kg/mouse of 5-flurouracil as standard } \\
\text { anticancer } \\
\text { G4 (EAC control): was inoculated } \\
\text { intraperitoneally with a single dose of EAC } \\
\text { cell line }(2 \times 106 \text { cells } / \text { mouse })+\text { normal } \\
\text { saline } \\
\text { G5: Coriander + EAC } \\
\text { G6: } 5 \text {-FU + EAC }\end{array}$ & $\begin{array}{c}21 \\
\text { days }\end{array}$ & $\begin{array}{c}\uparrow \operatorname{IgM}, \operatorname{IgG} \text { and IgA } \\
\text { levels } \\
\uparrow \text { Phagocytic activity } \\
\uparrow \text { skin thickness }\end{array}$ & [223] \\
\hline $\begin{array}{l}\text { Tualang } \\
\text { honey from } \\
\text { Malaysia }\end{array}$ & $\begin{array}{l}\text { Ten female } \\
\text { Sprague-Dawley } \\
\text { rats (age 6-8 } \\
\text { weeks) weighing } \\
\text { 140-170 g }\end{array}$ & $\begin{array}{c}\text { G1 }(\mathrm{HCD}): 12 \% \text { cholesterol diet } \\
\text { G2 }(\mathrm{HCD}+\mathrm{TH}): 12 \% \text { cholesterol diet along } \\
\text { with oral daily dose of } 1.4 \mathrm{~g} / \mathrm{kg} / \text { day of } \\
\text { tualang honey by gavage }\end{array}$ & $\begin{array}{c}6 \\
\text { weeks }\end{array}$ & $\begin{array}{c}\downarrow \mathrm{TC} \text { and TG } \\
\text { compared to the } \\
\text { control at } 7 \text { day } \\
\downarrow \text { Serum creatinine } \\
\text { level copared to G1 } \\
\text { after } 48 \mathrm{~h} \\
\text { No structural effect in } \\
\text { the HCD-fed rats }\end{array}$ & [224] \\
\hline $\begin{array}{c}\text { Buckwheat } \\
\text { honey }\end{array}$ & $\begin{array}{l}\text { Male Kunming } \\
\text { mice (18-22 g) }\end{array}$ & $\begin{array}{c}\text { G1 (Control): distilled water via gavage at } \\
0.22 \mathrm{~mL} / 10 \mathrm{~g} \text { bw } \\
\text { G2 (CCl4-treated mice): distilled water via } \\
\text { gavage at } 0.22 \mathrm{~mL} / 10 \mathrm{~g} \text { bw } \\
\text { G3: } 0.22 \mathrm{~g} / 10 \mathrm{~g} \text { bw of buckwheat honey } \\
\text { G4: } 0.5 \mathrm{mg} / 10 \mathrm{~g} \text { bw of silymarin via } \\
\text { gavage }\end{array}$ & $\begin{array}{c}10 \\
\text { weeks }\end{array}$ & $\begin{array}{c}\text { serum lipoprotein } \\
\text { oxidation inhibition } \\
\text { aspartate } \\
\text { aminotransferase and } \\
\text { alanine } \\
\text { aminotransferase } \\
\text { activities inhibition } \\
\uparrow \text { serum oxygen } \\
\text { radical absorbance } \\
\text { capacity } \\
\downarrow \text { Hepatic } \\
\text { malondialdehyde } \\
\uparrow \text { GSH-Px and SOD } \\
\text { activities } \\
\text { lymphocyte DNA } \\
\text { damage induced by } \\
\text { carbon tetrachloride } \\
\text { inhibition }\end{array}$ & [225] \\
\hline $\begin{array}{c}\text { Coriander } \\
\text { honey }\end{array}$ & $\begin{array}{l}21 \text { patients } \\
\text { between } 20 \text { and } 85 \\
\text { years }\end{array}$ & $\begin{array}{c}\mathrm{G} 1(n=22): \text { probiotics } \\
\mathrm{G} 2(n=21): \text { probiotic combination with } \\
\text { honey } \\
\mathrm{G} 3(n=24): \text { placebo }\end{array}$ & $\begin{array}{c}6 \\
\text { weeks }\end{array}$ & $\begin{array}{c}\downarrow \text { RBC, WBC, platelet } \\
\text { levels } \\
\downarrow \text { Iga levels from } 236.3 \\
\text { (58.6) to } 206.3 \text { (64.3) } \\
\text { mg/dL }\end{array}$ & [226] \\
\hline \multicolumn{6}{|c|}{ Antiproliferative } \\
\hline $\begin{array}{c}\text { Manuka } \\
\text { honey }\end{array}$ & $\begin{array}{l}\text { male mice at } 8-12 \\
\text { weeks of age }\end{array}$ & $\begin{array}{c}50 \%(w / v) \text { manuka honey intravenously, } 10 \\
\mathrm{mg} / \mathrm{kg} \text { taxol twice weekly }\end{array}$ & $\begin{array}{c}3-4 \\
\text { weeks }\end{array}$ & $\begin{array}{l}\uparrow \text { Caspase-3 } \\
\uparrow \text { Survival rate }\end{array}$ & [185] \\
\hline
\end{tabular}

DMBA, carcinogen 7,12-dimethylbenz $(\alpha)$ anthracene; VEGF, vascular endothelial growth factor; HDL-C, high density lipoprotein cholesterol; HFD, high-fat diet; FPG, fasting plasma glucose; bw, body weight; TAS, total antioxidant status; CAT, catalase; GPx, glutathione peroxidise; GR, glutathione reductase, GST glutathione-S-transferase; SOD, superoxide dismutase; LPO, Lipid peroxidation; ISO,Isoproterenol; HbA1c, Haemoglobin A1c; HDL-C, high density lipoprotein cholesterol; LDL-C, low density lipoprotein cholesterol; VLDL-C, very low density lipoprotein cholesterol; TC, total cholesterol; TG, triglycerides; LPO, lipoprotein oxidation; HCD, high cholesterol diet; AST, aspartate aminotransferase; CRP, C-reactive protein; SSFT, subscapular skin fold thickness; FSG, fasting serum glucose; FCP, fasting C-peptide; PCP, 2h postprandial C-peptide; LDL, low density lipoprotein cholesterol; CHD, Coronary Heart Disease; RBG, random blood glucose; HDL, high density lipoproteins; SBP, systolic blood pressure; DBP, Diastolic Blood Pressure; $\uparrow$ high/increase; $\downarrow$ low/decrease; $\leftrightarrow$ moderate/medium. 


\subsection{Wound Healing}

Since ancient times, honey has been used for the treatment of wounds. The discovery of antibiotics has led to a decrease in honey use, but the development of antibiotic resistance increased the interest in honey again due to its antibacterial properties. However, attention should be paid to the quality of honey used in medical practices. Plants in honey harvest areas are exposed to herbicides and pesticides, industrial heavy metals and environmental pollution contaminated with antibiotics, and, as a result, toxic compounds can be found in honey. In addition, the harmful microbial load of honey is ignored. The content and standards of honey used especially for health purposes should be determined [227]. There is evidence that honey can heal partial thickness burns and postoperative infected wounds more quickly and effectively than conventional treatments [228]. Recently, honey has been extensively applied in wound treatment as an alternative to more expensive and advanced wound products. It reduces redness, swelling and pain and, when applied, there is usually no discomfort other than a slight stinging sensation [229].

\subsection{Antioxidant Activity}

As exemplified in the previous sections, monofloral honey is rich in both enzymatic and non-enzymatic antioxidants, polyphenols and minerals. In the study conducted by Omotayo et al. (2010) [205], it was investigated whether tualang honey could reduce hyperglycemia and ameliorate oxidative stress in streptozotocin-induced diabetic rats. The honey-treated groups showed an increase activity of catalase, glutathione peroxidase, glutathione reductase and glutathione-S-transferase compared to control. The same was noticed in the study of Erejuwa et al. [206], which showed that the combination of glibenclamide, metformin and taulang honey significantly up-regulated CAT activity, reduced TBARS levels and down-regulated GPx activity.

Sibel et al. [208] showed that Rhododendron honey treatments showed an antioxidant effect on blood plasma and organ tissues Thus, a significant increase in GTX was shown at a high dose of mad honey and decreased levels of MDA levels in the group administered a low dose of honey $(0.1 \mathrm{~g} / \mathrm{kg} / \mathrm{bw})$. Furthermore, the honey-administered group, at low doses of honey, was closely related to the control group in lung, heart, spleen, testicle and epididymis tissues and medium doses of honey in the testicle and epididymis.

Eraslan et al. [209] demonstrated that the administration of pine honey alleviated the tissue MDA levels and CAT, SOD and GSH-Px activities in the trichlorfon-administered group. Thus, they demonstrated that, in order to minimize the risk of foodborne trichlorfon intoxication, as well as its adverse effects, pine honey may be safely included in the daily human diet. In a different study, Bezerra et al. [210] showed the positive effect of malicia honey on the lipid metabolism, antioxidant status and intestinal health of rats with dietinduced dyslipidaemia. The dyslipidaemia group that received honey showed lower values of GPx and higher MDA levels.

\subsection{Anti-Obesity}

Honey has the potential to control obesity by reducing excess weight gain and other obesity parameters such as triglyceride levels. However, its effects on cells that store lipids (adipocytes) are still unclear. In the study conducted in order to observe the effects of pineapple honey on adiposity growth and lipid accumulation in vitro, it was determined that pineapple honey had a total phenolic content of $0.0379 \pm 0.001 \mathrm{mg} / 100 \mathrm{~mL} \mathrm{GAE}$ and a total flavonoid content of $0.098 \pm 0.001 \mathrm{mg}$ catechin $/ \mathrm{kg}$. It has been found to significantly inhibit the proliferation of adipocytes starting at $6.25 \%$ of the pineapple honey concentration. In addition, honey was found to significantly reduce lipid droplet size between $33.78 \%$ and $70.36 \%$, compared with the control [184].

The influence of Clover honey on weight gain, adiposity and blood lipid profile on Sprague-Dawley rats has been evaluated [213]. They were equally divided into two groups and provided either clover honey or sucrose. After 33 days, for the honey-fed group, the bw was $14.7 \%$ lower, alongside a $13.3 \%$ lower consumption of food. Compared to control, the 
epididymal fat weight was $20.1 \%$ lower, as well as the serum concentrations of triglycerides (29.6\%) and leptin (21.6\%). Their results clearly demonstrated that, in comparison with sucrose, honey reduced weight gain and adiposity, due to lower food intake, as well as promoted lower serum triglycerides.

In a different aspect, the high fat diet rats fed with Gelam and Acacia honeys had lower consumption of food, as well as a lower adiposity index compared to the high fat diet group. Furthermore, rats fed with Acacia honey showed a significant increase in the relative organ weight compared to the control group, particularly the liver, heart and lung [215]. Even though, in the experimental diabetes mellitus, the supplementation with tualang honey resulted in weight gain of diabetic rats, its supplementation in human (especially obese) diabetic patients may necessitate a dose adjustment and reduced calorie intake [205].

\subsection{Gastrointestinal Protective Effects}

Honey produced from medicinal plants is generally a great hope for human health. The chemical composition and gastrointestinal protective effects of a new monofloral honey from Prunella vulgaris (PVH) have been identified, and it has been reported to provide basic data on PVH for future applications supporting the prevention of colitis [148]. Furthermore, Rhododendron honey is used as an alternative treatment for gastritis, stomach ulcer, constipation, hypertension, coronary heart disease and impotence [229].

Kocyigit et al. [183] showed that, due to its high phenolic and antioxidant contents, Quercus pyrenaica honeydew honey were tested against gastric cancer cells.

Honeydew honey had proliferative effects due to its antioxidant activity, and high concentrations showed cytotoxic, genotoxic, and apoptotic effects in the tested cancer cells. All these effects were higher with Quercus application compared with that of polyfloral honey, which possessed lower phenolic content. Their results demonstrated that honeydew honey may contribute to the future development of therapeutics in patient's suffering from several cancers.

Oral pretreatment with Chestnut honey $(2 \mathrm{~g} / \mathrm{kg})$, once daily for seven consecutive days, prevented indomethacin-induced gastric lesions in rats, reduced the ulcer index, microvascular permeability and stomach's myeloperoxidase activity [212].

\subsection{Anti-Fatigue and Antidepressant Effects}

It has been stated that honey has a fatigue-relieving and soothing quality due to its alkaline balance. Honey, which also affects the nervous system, is good for headaches, insomnia and depression with its antidepressant and sedative properties [230].

\subsection{Antibacterial and Antimicrobial Activity}

Honey provides benefits against Streptococcus mutans infections, dental plaque and caries and gingivitis and bad breath, and also contributes to the prevention of side effects associated with the treatment of head and neck cancers, namely radiation-induced mucositis, xerostomia and poor wound healing [231,232]. Methylglyoxal (MGO) is the main antimicrobial marker associated with the use of Mānuka honey as a topical dressing. It is predicted that MGO derived from Mānuka honey may play a role in the enhancement of microbial detection by MAIT cells, which may help MAIT cells (Mucosal-associated invariant $\mathrm{T}$ cells) to control microbial infection and systemic immune homeostasis [233]. A recent study showed the differences between the antibacterial effects of Hovenia and Acacia honeys [153]. The minimum inhibitory activity of Hovenia and Acacia honeys was evaluated against gram positive (S. aureus and L. monocytogenes) and gram negative (E. coli O157:H7 and S. typhimurium) bacteria. Their results showed similar MIC for both honeys, as follows: $25-50 \%(w / v)$ against E. coli O157:H7 and S. typhimurium and 25\% $(w / v)$ against $S$. aureus and L. monocytogenes. Furthermore, the MIC values of artificial honey (sugar constituted) against foodborne bacteria exceeded $50 \%(w / v)$, indicating that a part 
of antibacterial activity of Hovenia and Acacia monofloral honeys was derived from the TPC and TFC.

Moghadam and Khaledi (2021) [234] studied the minimum inhibitory concentration and the minimum bactericidal concentration of six Iranian honey samples in comparison with Manuka honey against reference strains of Staphylococcus aureus (ATCC 29737), Pseudomonas aeruginosa (ATCC 27853), Klebsiella pneumonia (ATCC 10031) and Escherichia coli (ATCC 10536). Their results showed high antimicrobial and anti-biofilm activity in Iranian honeys compared to Manuka honey.

Majtan and Majtan (2010) [235] studied the antibacterial properties of Slovak honey types such as Acacia, Canola, Meadow and Forest, compared to Manuka honey. The results showed that forest honey had an inhibitory activity similar to that of manuka honey for some bacteria. Forest honey is more effective against Proteus sp. and Pseudomonas aeruginosa than manuka honey. In recent years, increased bacterial resistance to a lot of antibiotics and the various complications with chronic wounds are presented. Boateng and Diunase (2015) [128] compared Cameroonian honeys in the respect of physicochemical, antioxidant and antibacterial activity (that may contribute to the functional wound healing) to those of Manuka honey.

\subsection{Antidiabetic Effects}

Multiple reports have demonstrated the positive role of honey in regulating the blood glucose level. However, due to its high sugar content, honey is considered detrimental to diabetics. As stated in Section 7, fructose content in monofloral honey varies from $23 \%$ in Eucalyptus to $45 \%$ in Heather, followed by Fennel with $44.9 \%$. Therefore, its high fructose content along with minerals, phenolic acids and flavonoids has a role in regulating blood glucose levels. Furthermore, Omotayo et al., 2010 [205] showed that consumption of tualang honey significantly decreased the elevated levels of TBARS in streptozotocininduced diabetic rats, showing that the honey-treated diabetic rats had reduced lipid oxidative damage.

In a recent study by Whitfield et al. [220], the mixture of Kanuka honey with chromium, cinnamon and magnesium was studied for its effect on lipid profile, glycaemic control and weight in 12 patients with type 2 diabetes. Based on their results, consumption of the $53.5 \mathrm{~g}$ honey mixture for 40 days significantly increased the bw and improved lipid parameters in the subjects. Additionally, susceptibility in the increase of HDL and reduction of systolic blood pressure was also noticed. Finally, the honey mixture did not affect glycaemic control and the metabolism of glucose.

\subsection{In Vitro Studies Correlated to Polyphenols}

Many of the polyphenols found in honey, such as caffeic acid, caffeic acid phenyl esters, chrysin, galangin, quercetin, kaempferol, acacetin, pinocembrin, pinobanksin and apigenin have potential in the treatment of cancer. Jaganathan and Mandal (2009) [236] reviewed the antiproliferative effect of polyphenols from honey in various cancer cell lines. Manuka honey has an antiproliferative activity on three different cancer cell lines: murine melanoma (B16.F1), colorectal carcinoma (CT26) and human breast cancer (MCF-7) cells in vitro. It is effective at concentrations as low as $0.6 \%(w / v)$ [182]. Alvarez Suarez et al. 2012 [66] studied the protective effect of such unifloral honeys against lipid peroxidation in an in vitro model of rat liver homogenates and the ability of the phenolic extracts of Turbina corymbosa L. (i.e., Christmas vine) and Gouania polygama (Linen vine) honeys to inhibit the oxidative damage induced by the $2,2^{\prime}$-azobis(2-methylpropionamidine) dihydrochloride in erythrocytes.

Tsiapara et al. (2009) [114] presented antiprolifertive effects from Greek honey extracts from thyme, pine and fir honey on breast cancer (MCF-7), prostate cancer (PC-3) and endometrial cancer (Ishikawa) cells. Thyme honey reduced the viability of Ishikawa and PC-3 cells. They concluded that Greek honeys are rich in phenolic compounds and may prevent cancer-related processes in breast, prostate and endometrial cancer cells. 
In another study, Jaganathan (2012) [237] examined the apoptotic effect of caffeic acid, one of the phenolic constituents of honey, in HCT 15 colon cancer cells. The author promoted the caffeic acid as a candidate in the chemoprevention of colon cancer. The caffeic acid inhibited the colon cancer cell proliferation in a dose-dependent manner. The antiproliferative effect of caffeic acid was estimated using 3-(4,5-dimethylthiazol-2-yl)-2,5-diphenyl tetrazolium bromide (MTT) assay. Swellam et al. (2003) [238] examined the effect of pure unfractionated honey in three human bladder cancer cell lines (T24, 253J and RT4) and in one murine bladder cell line (MBT-2) using MTT assay. The authors received significant inhibition of the proliferation of T24 and MBT-2 cell lines by 1-25\% honey and of RT4 and 253 J cell lines by $6-25 \%$ honey.

Pichichero et al. (2010) [161] investigated the antiproliferative effect of honey or chrysin (5,7-dihydroxyflavone) on human (A375) and murine (B16-F1) melanoma cell lines with MTT assay and Trypan Blue Exclusion Test. Chrysin is a natural flavone found in Acacia honey. Both tests showed that these compounds can induce an antiproliferative effect on melanoma cells. The same authors concluded that the antiproliferative effects of honey are due to the presence of chrysin. In this respect, chrysin is a potential candidate in the prevention and treatment of cancer. Aliyu et al. (2012) [155] provided evidence on the apoptotic role of Acacia honey from Pakistan on the PC-3 Human prostate cancer cell line. The possible mechanism of this process is the modulation of pro-inflammatory cytokines and regulation of prostate specific antigen in vitro.

The antitumor effects of honey on liver cancer cells have been reported by Aziz Baiomy et al. (2009) [239]. The authors reported that honey extracts exerted cytotoxic, antimetastatic and anti-angiogenic effects in HepG2 cells.

Anticancer activity of honey has been proved against various cancer cell lines and tissues in animals and humans [240], and multiple reviews summarise the anticancerogenic properties of different honey types and components of honey [16,241-243]. Tualang honey is a Malaysian multifloral jungle honey with many potential health benefits such as antimicrobial, anti-inflammatory, antioxidant, antimutagenic, antitumor, antidiabetic and wound-healing properties. Some of its properties are similar to Manuka honey. The differences include higher phenolics and flavonoids in Tualang honey. Tualang honey is also more effective against some gram-negative bacterial strains in burn wounds compared to the Manuka honey. The honey is produced by Apis dorsata, which builds hives on branches of tall Tualang trees located mainly in Peninsular Malaysia [16].

Manuka honey, even at lower concentrations of $0.6 \%(w / v)$, inhibited the cell proliferation in multiple cell lines (human breast cancer MCF-7, murine melanoma B16.F1 and mouse colon carcinoma CT26) in a dose and time dependent manner [182].

In a recent study, Abd Kadir et al., (2013) [207] studdied the inhibitory effect of Malaysian tualang honey on the development of 7,12-dimethylbenz $(\alpha)$ anthracene (DMBA)induced breast cancer in rats. Their results showed that the untreated DMBA-induced breast cancer rats (control rats) developed tumors earlier compared to the honey-treated DMBA-induced breast cancer rats. The control rats also showed a marked increase in tumor size over a shorter period. On the contrary, a reduction in the growth and size were noticeably reduced in the honey-treated DMBA-induced breast cancer rats compared to the untreated cancer rats. Furthermore, a lower number of tumors were noticed in the honey-treated rats compared to the controls. Even though not statistically significant, an increase in apoptotic index was noticed by higher honey doses. Higher grade tumours were observed in the untreated rats, compared to lower or medium grade ones reported in the honey-treated group. The histological analysis also revealed that the cancer cells from the honey-treated rats were more identical, with denser nuclei, while those of the control rats had more pleomorphic cells with more prominent nuclei. Finally, lower prominent vasculature surrounding the tumor nodules and significantly reduced weight and volume in the tumor mass were noticed (paler, smaller and softer with necrosis spots) in the honey-treated group. 


\section{Conclusions}

Numerous honey compounds act as natural antioxidants. From ancient times to nowadays, honey has had a potential role in contributing to human health. Bee honey is chemically very complex, and the chemical composition strongly depends on its botanical origin. Monofloral honeys are also an economic income source for many countries.

The locally available honey types in different countries are rich in bioactive components displaying excellent applications for human health. There are approximately 200 compounds in honey. The variety of these compounds results in different color, taste, honey type and therapeutic activities. Honey might be utilized as a potential source of natural antioxidants. Furthermore, the consumption of honey has high nutritional and therapeutic values. The concentration of different compounds in honey depends mainly on various factors, such as floral source and honey type, as well as environmental and processing factors. These factors affect the biological activities of each type of honey in the world.

In brief, monofloral honeys present a variety of dietary phytochemical compounds with functional properties such as phenolic acids, minerals, phenolics and flavonoids. Therefore, considering the food industry and the positive effects on human health, monofloral honeys have tremendous potential for the production and use as natural and functional ingredients with special attention to their use in the medical field. To our knowledge, this is the first study of the antioxidant properties, mineral composition and health properties of monofloral honey types.

Author Contributions: Important contributions to design and also to prepare the manuscript: R.M., M.C.-C., T.O., R.B., and E.T. The manuscript was revised by: R.M., E.T., R.B., B.Y. and D.C.V. All authors have read and agreed to the published version of the manuscript.

Funding: The publication was funded by PN-III-P1-1.2-PCCDI-2017-0056-2PCCDI.

Conflicts of Interest: The authors declare no conflict of interest.

\section{References}

1. Requier, F. Bee Colony Health Indicators: Synthesis and Future Directions. CAB Rev. 2019, 14, 1-12. [CrossRef]

2. Kulhanek, K.; Steinhauer, N.; Rennich, K.; Caron, D.M.; Sagili, R.R.; Pettis, J.S.; Ellis, J.D.; Wilson, M.E.; Wilkes, J.T.; Tarpy, D.R.; et al. A National Survey of Managed Honey Bee 2015-2016 Annual Colony Losses in the USA. J. Apic. Res. 2017, 56, 328-340. [CrossRef]

3. Goodrich, B.K. Do More Bees Imply Higher Fees? Honey Bee Colony Strength as a Determinant of Almond Pollination Fees. Food Policy 2019, 83, 150-160. [CrossRef]

4. Topal, E.; Yücel, B.; Altunoğlu, E.; Acar, A.A.; Kösoğlu, M.; Tekintaş, F.E. Bal ve Bombus Arısı Tozlaşmasının ve Doğal Tozlayıcıların Kirazda Meyve Tutumu ve Kalitesi Üzerine Etkisi. J. Aari. 2018, 28, 61-74.

5. Mărgăoan, R.; Aradăvoaicei, S.; Cornea-Cipcigan, M.; Sisea, C.R. The Role of Pollinators in Maintaining the Biodiversity of Some Exotic Cultures. Int. J. Envrion. Res. Technol. 2019, 2, 17-23.

6. Potts, S.G.; Biesmeijer, J.C.; Kremen, C.; Neumann, P.; Schweiger, O.; Kunin, W.E. Global Pollinator Declines: Trends, Impacts and Drivers. Trends Ecol. Evol. 2010, 25, 345-353. [CrossRef] [PubMed]

7. Goulson, D.; Nicholls, E.; Botías, C.; Rotheray, E.L. Bee Declines Driven by Combined Stress from Parasites, Pesticides, and Lack of Flowers. Science 2015, 347, 1255957. [CrossRef] [PubMed]

8. McMenamin, A.J.; Genersch, E. Honey Bee Colony Losses and Associated Viruses. Curr. Opin. Insect Sci. $2015,8,121-129$. [CrossRef] [PubMed]

9. Sanchez-Bayo, F.; Goulson, D.; Pennacchio, F.; Nazzi, F.; Goka, K.; Desneux, N. Are Bee Diseases Linked to Pesticides?-A Brief Review. Environ. Int. 2016, 89, 7-11. [CrossRef]

10. Neov, B.; Georgieva, A.; Shumkova, R.; Radoslavov, G.; Hristov, P. Biotic and Abiotic Factors Associated with Colonies Mortalities of Managed Honey Bee (Apis mellifera). Diversity 2019, 11, 237. [CrossRef]

11. Stanimirović, Z.; Glavinić, U.; Ristanić, M.; Aleksić, N.; Jovanović, N.; Vejnović, B.; Stevanović, J. Looking for The Causes of and Solutions to The Issue of Honey Bee Colony Losses. Acta Vet. Beogr. 2019, 69, 1-31. [CrossRef]

12. Mărgăoan, R.; Strant, M.; Varadi, A.; Topal, E.; Yücel, B.; Cornea-Cipcigan, M.; Campos, M.G.; Vodnar, D.C. Bee Collected Pollen and Bee Bread: Bioactive Constituents and Health Benefits. Antioxidants 2019, 8, 568. [CrossRef] [PubMed]

13. Hussein, A.E.; El-Ansari, M.K.; Zahra, A.A. Effect of the Honeybee Hybrid and Geographic Region on the Honey Bee Venom Production. J. Plant Prot. Pathol. 2019, 10, 171-176. [CrossRef]

14. Bărnuţiu, L.I.; Mărghitaş, L.; Dezmirean, D.; Bobiş, O.; Mihai, C.; Pavel, C. Physicochemical Composition of Apilarnil (Bee Drone Larvae). Lucr. Ştiinţifice Ser. Zooteh. 2013, 59, 199-202. 
15. Estevinho, M.L.M.F.; Rodrigues, S.S.Q.; Pereira, A.P.; Feás, X. Portuguese Bee Pollen: Palynological Study, Nutritional and Microbiological Evaluation. Int. J. Food Sci. Technol. 2012, 47, 429-435. [CrossRef]

16. Ahmed, S.; Sulaiman, S.A.; Baig, A.A.; Ibrahim, M.; Liaqat, S.; Fatima, S.; Jabeen, S.; Shamim, N.; Othman, N.H. Honey as a Potential Natural Antioxidant Medicine: An Insight into Its Molecular Mechanisms of Action. Oxidative Med. Cell. Longev. 2018, 8367846. [CrossRef]

17. Gürbüz, S.; Güngör Çelikel, A.; Toprak, A. Sağlık ve Beslenme Açısından Bal. Anadolu, I. In Uluslararası Multidisipliner Çalışmalar Kongresi; Sayfa: Diyarbakır, Turkey, 2018; pp. 692-695.

18. Samarghandian, S.; Farkhondeh, T.; Samini, F. Honey and Health: A Review of Recent Clinical Research. Pharmacogn. Res. 2017, 9 , 121-127.

19. Khalil, M.I.; Sulaiman, S.A.; Gan, S.H. High 5-Hydroxymethylfurfural Concentrations are Found in Malaysian Honey Samples Stored for More Than One Year. Food Chem. Toxicol. 2010, 48, 2388-2392. [CrossRef]

20. Gheldof, N.; Wang, X.H.; Engeseth, N.J. Buckwheat Honey Increases Serum Antioxidant Capacity in Humans. J. Agric. Food Chem. 2003, 51, 1500-1505. [CrossRef] [PubMed]

21. Çakıcı, N.; Yassıhüyük, N. Balın Antioksidan Aktivitesi ve Antibakteriyel Etkisi. Arıcılık Araştırma Dergisi 2013, 9, 12-13.

22. Malkoç, M.; Kara, Y.; Özkök, A.; Ertürk, Ö.; Kolaylı, S. Karaçalı (Paliurus spina-christi Mill.) Balının Karakteristik Özellikleri. Uludag Bee J. 2019, 19, 69-81.

23. Özenirler, Ç. Dandelion Honey: A New Monofloral Honey Record for Turkey. Uludag Bee J. 2018, 18, 87-93.

24. Gül, A.; Pehlivan, T. Antioxidant Activities of Some Monofloral Honey Types Produced Across Turkey. Saudi J. Biol. Sci. 2018, 25, 1056-1065. [CrossRef]

25. Can, Z.; Yildiz, O.; Sahin, H.; Turumtay, E.A.; Silici, S.; Kolayli, S. An Investigation of Turkish Honeys: Their Physico-Chemical Properties, Antioxidant Capacities and Phenolic Profiles. Food Chem. 2015, 180, 133-141. [CrossRef] [PubMed]

26. Can, Z. Biyoaktiviteleri Yönünden Türkiye Florasına Ait Baskın Ballar Ile Manuka Ballarının Karşılaştırılması. Ph.D. Thesis, Karadeniz Teknik Üniversitesi/Fen Bilimleri Enstitüsü, Trabzon, Turkey, 2014.

27. Ekmekci, N. Investigation of Antimutagenic Effects of Some Local Honey Kinds in Turkey by Salmonella/Microsome (Ames) Test System. Ph.D. Thesis, Selçuk Üniversitesi Fen Bilimleri Enstitüsü, Konya, Turkey, 2010.

28. Ölmez, Ç. Türkiye'de Üretilen Farklı Çiçek ve Salgı Bal Çeşitlerinin Bazı Kalitatif ve Besinsel Özellikleri. Ph.D. Thesis, Selçuk Üniversitesi Fen Bilimleri Enstitüsü, Konya, Turkey, 2009.

29. Haroun, M.I. Türkiye'de Üretilen Bazı Çiçek ve Salgı Ballarının Fenplik Asit ve Flavonoid Profilinin Belirlenmesi. Ph.D. Thesis, Ankara Üniversitesi Fen Bilimleri Enstitüsü Gıda Mühendisliği Anabilim Dalı, Ankara, Turkey, 2006.

30. Silici, S.; Tolon, B. Further Chemical and Palynological Properties of Some Unifloral Turkish Honeys. In Proceedings of the First German Congress for Bee Products and Apitherapy, Passau, Germany, 23-24 March 2002.

31. Küçük, M.; Kolaylı, S.; Karaoğlu, Ş.; Ulusoy, E.; Baltacı, C.; Candan, F. Biological Activities and Chemical Composition of Three Honeys of Different Types from Anatolia. Food Chem. 2007, 100, 526-534. [CrossRef]

32. Balkanska, R.; Stefanova, K.; Stoikova-Grigorova, R.; Manolova, V. Preliminary Study of DNA Extraction from Bulgarian Honeys and Its Amplification by PCR for Botanical Identification. Food Health 2018, 3, 194-201. [CrossRef]

33. Nikolova, K.; Pisanova, E.; Ivanova, I. Use of Cluster and Factor Analysis for Grouping Bulgarians Honeys according to Botanical Origin. J. Commun. Comput. 2017, 14, 53-59. [CrossRef]

34. Nikolova, K.; Gentscheva, G.; Ivanova, E. Survey of the Mineral Content and Some Physico-Chemical Parameters of Bulgarian Bee Honeys. Bulg. Chem. Commun. 2013, 45, 244-249.

35. Atanassova, J.; Lazarova, M.; Yurukova, L. Significant Parameters of Bulgarian Honeydew Honey. J. Cent. Eur. Agric. 2016, 17, 640-651. [CrossRef]

36. Pauliuc, D.; Dranca, F.; Oroian, M. Antioxidant Activity, Total Phenolic Content, Individual Phenolics and Physicochemical Parameters Suitability for Romanian Honey Authentication. Foods 2020, 9, 306. [CrossRef]

37. Berhilevych, O.; Kasianchuk, V.; Kukhtyn, M.; Dimitrijevich, L.; Marenkova, T. The Study Correlation between Physicochemical Properties, Botanical Origin and Microbial Contamination of Honey from the South of Ukraine. Potravin. Slovak. J. Food Sci. 2019, 13, 863-869. [CrossRef]

38. Kotenko, P.; Miyaura, R. Regional Typology of Beekeeping and Consumption of Honeybee Products in Ukraine. J. Agric. Sci. Tokyo Univ. Agric. 2019, 64, 11-19.

39. Castiglioni, S.; Stefano, M.; Astolfi, P.; Carloni, P. Chemometric Approach to the Analysis of Antioxidant Properties and Colour of Typical Italian Monofloral Honeys. Int. J. Food Sci. Technol. 2017, 52, 1138-1146. [CrossRef]

40. Di Marco, G.; Manfredini, A.; Leonardi, D.; Canuti, L.; Impei, S.; Gismondi, A.; Canini, A. Geographical, Botanical and Chemical Profile of Monofloral Italian Honeys as Food Quality Guarantee and Territory Brand. Plant Biosyst. 2017, 153, 450-463. [CrossRef]

41. Mattonai, M.; Parri, E.; Querci, D.; Degano, I.; Ribechini, E. Development and Validation of an HPLC-DAD and HPLC/ESI-MS2 Method for the Determination of Polyphenols in Monofloral Honeys from Tuscany (Italy). Microchem. J. 2016, 126, 220-229. [CrossRef]

42. Parri, E.; Santinami, G.; Domenici, V. Front-Face Fluorescence of Honey of Different Botanic Origin: A Case Study from Tuscany (Italy). Appl. Sci. 2020, 10, 1776. [CrossRef]

43. Tuberoso, C.I.; Bifulco, E.; Jerkovic, I.; Caboni, P.; Cabras, P.; Floris, I. Methyl Syringate: A Chemical Marker of Asphodel (Asphodelus Microcarpus Salzm. Et Viv.) Monofloral Honey. J. Agric. Food Chem. 2009, 57, 3895-3900. [CrossRef] [PubMed] 
44. Gonçalves, J.; Ribeiro, I.; Marçalo, J.; Rijo, P.; Faustino, C.; Pinheiro, L. Physicochemical, Antioxidant and Antimicrobial Properties of Selected Portuguese Commercial Monofloral Honeys. J. Food Nutr. Res. 2018, 6, 645-654. [CrossRef]

45. Alves, A.; Ramos, A.; Gonçalves, M.M.; Bernardo, M.; Mendes, B. Antioxidant Activity, Quality Parameters and Mineral Content of Portuguese Monofloral Honeys. J. Food Compos. Anal. 2013, 30, 130-138. [CrossRef]

46. Silva, L.R.; Videira, R.; Monteiro, A.P.; Valentão, P.; Andrade, P.B. Honey from Luso Region (Portugal): Physicochemical Characteristics and Mineral Contents. Microchem. J. 2009, 93, 73-77. [CrossRef]

47. Bodó, A.; Radványi, L.; Kőszegi, T.; Csepregi, R.; Nagy, D.U.; Farkas, Á.; Kocsis, M. Melissopalynology, Antioxidant Activity and Multielement Analysis of Two Types of Early Spring Honeys from Hungary. Food Biosci. 2020, 35, 100587. [CrossRef]

48. Czipa, N.; Alexa, L.; Phillips, C.J.; Kovács, B. Macro-Element Ratios Provide Improved Identification of the Botanical Origin of Mono-Floral Honeys. Eur. Food Res. Technol. 2018, 244, 1439-1445. [CrossRef]

49. Czipa, N.; Andrási, D.; Kovács, B. Determination of Essential and Toxic Elements in Hungarian Honeys. Food Chem. 2015, 175, 536-542. [CrossRef]

50. Bouhlali, E.D.T.; Bammou, M.; Sellam, K.; El Midaoui, A.; Bourkhis, B.; Ennassir, J.; Alem, C.; Filali-Zegzouti, Y. Physicochemical Properties of Eleven Monofloral Honey Samples Produced in Morocco. Arab J. Basic Appl. Sci. 2019, 26, 476-487. [CrossRef]

51. Aazza, S.; Lyoussi, B.; Antunes, D.; Miguel, M.G. Physicochemical Characterization and Antioxidant Activity of 17 Commercial Moroccan Honeys. Int. J. Food Sci. Nutr. 2014, 65, 449-457. [CrossRef]

52. Chakir, A.; Romane, A.; Marcazzan, G.L.; Ferrazzi, P. Physicochemical Properties of Some Honeys Produced from Different Plants in Morocco. Arab J. Ochem. 2016, 9, S946-S954. [CrossRef]

53. Mohamed, M.; Sirajudeen, K.N.S.; Swamy, M.; Yaacob, M.; Sulaiman, S. Studies on the Antioxidant Properties of Tualang Honey of Malaysia. Afr. J. Tradit. Complement. Altern. Med. 2010, 7, 59-63. [CrossRef]

54. Yaacob, N.S.; Nengsih, A.; Norazmi, M. Tualang Honey Promotes Apoptotic Cell Death Induced by Tamoxifen in Breast Cancer Cell Lines. Evid. Based Complement. Altern. Med. 2013, 2013, 989841. [CrossRef]

55. Alvarez-Suarez, J.M.; Gasparrini, M.; Forbes-Hernández, T.Y.; Mazzoni, L.; Giampieri, F. The Composition and Biological Activity of Honey: A Focus on Manuka Honey. Foods 2014, 3, 420-432. [CrossRef]

56. Kato, Y.; Umeda, N.; Maeda, A.; Matsumoto, D.; Kitamoto, N.; Kikuzaki, H. Identification of a Novel Glycoside, Leptosin, as a Chemical Marker of Manuka Honey. J. Agric. Food Chem. 2012, 60, 3418-3423. [CrossRef] [PubMed]

57. Semprini, A.; Singer, J.; Braithwaite, I.; Shortt, N.; Thayabaran, D.; McConnell, M.; Weatherall, M.; Beasley, R. Kanuka Honey Versus Aciclovir for the Topical Treatment of Herpes Simplex Labialis: A Randomised Controlled Trial. BMJ Open 2019 , 9, e026201. [CrossRef]

58. Vanhanen, L.P.; Emmertz, A.; Savage, G.P. Mineral Analysis of Mono-floral New Zealand Honey. Food Chem. 2011, 128, 236-240. [CrossRef] [PubMed]

59. Bobis, O.; Mãrghitas, L.A.; Dezmirean, D.S.; Bãrnutiu, L.I.; Mãrgãoan, R.; Bogdan Gherman, B.; Bonta, V. The Importance of Melissopalynology in Addition to Physical-chemical Analysis on Botanical Authenticity Testing of Monofloral Honey. Bull. UASVM Anim. Sci. Biotechnol. 2013, 70, 24-30.

60. Bong, J.; Loomes, K.M.; Lin, B.; Stephens, J.M. New Approach: Chemical and Fluorescence Profiling of NZ Honeys. Food Chem. 2018, 267, 355-367. [CrossRef] [PubMed]

61. Bobis, O.; Moise, A.R.; Ballesteros, I.; Reyes, E.S.; Durán, S.S.; Sánchez-Sánchez, J.; Quintanai, S.C.; Giampieri, F.; Battino, M.; Alvarez-Suarez, J.M. Eucalyptus honey: Quality parameters, chemical composition and health-promoting properties. Food Chem. 2020, 325, 126870. [CrossRef]

62. Andrade, P.; Ferreres, F.; Amaral, M.T. Analysis of Honey Phenolic Acids by HPLC, Its Application to Honey Botanical Characterization. J. Liq. Chromatogr. Relat. Technol. 1997, 20, 2281-2288. [CrossRef]

63. Yao, L.; Datta, N.; Tomas-Barberan, F.A.; Ferreres, F.; Martos, I.; Singanusong, R. Flavonoids, Phenolic Acids and Abscisic Acid in Australian and New Zealand Leptospermum Honeys. Food Chem. 2003, 81, 159-168. [CrossRef]

64. Das, A.; Datta, S.; Mukherjee, S.; Bose, S.; Ghosh, S.; Dhar, P. Evaluation of Antioxidative, Antibacterial and Probiotic Growth Stimulatory Activities of Sesamum Indicum Honey Containing Phenolic Compounds and Lignans. LWT Food Sci. Technol. 2015, 61, 244-250. [CrossRef]

65. Gašić, U.M.; Natić, M.M.; Mišić, D.M.; Lušić, D.V.; Milojković-Opsenica, D.M.; Tešić, Ž.L.; Lušić, D. Chemical Markers for the Authentication of Unifloral Salvia Officinalis, L. Honey. J. Food Compos. Anal. 2015, 44, 128-138. [CrossRef]

66. Alvarez-Suarez, J.M.; Giampieri, F.; González-Paramás, A.M.; Damiani, E.; Astolfi, P.; Martinez-Sanchez, G.; Bompadre, S.; Quiles, J.L.; Buelga, C.S.; Battino, M. Phenolics from Monofloral Honeys Protect Human Erythrocyte Membranes Against Oxidative Damage. Food Chem. Toxicol. 2012, 50, 1508-1516. [CrossRef]

67. Ranneh, Y.; Ali, F.; Zarei, M.; Akim, A.M.; Abd Hamid, H.; Khazaai, H. Malaysian Stingless Bee and Tualang Honeys: A Comparative Characterization of Total Antioxidant Capacity and Phenolic Profile Using Liquid Chromatography-Mass Spectrometry. LWT 2018, 89, 1-9. [CrossRef]

68. Perna, A.; Intaglietta, I.; Simonetti, A.; Gambacorta, E. A Comparative Study on Phenolic Profile, Vitamin C Content and Antioxidant Activity of Italian Honeys of Different Botanical Origin. Int. J. Food Sci. Technol. 2013, 48, 1899-1908. [CrossRef]

69. Arráez-Román, D.; Gómez-Caravaca, A.M.; Gómez-Romero, M.; Segura-Carretero, A.; Fernández-Gutiérrez, A. Identification of Phenolic Compounds in Rosemary Honey Using Solid-Phase Extraction by Capillary Electrophoresis-Electrospray IonizationMass Spectrometry. J. Pharm. Biomed. Anal. 2006, 41, 1648-1656. [CrossRef] 
70. Mannina, L.; Sobolev, A.P.; Di Lorenzo, A.; Vista, S.; Tenore, G.C.; Daglia, M. Chemical Composition of Different Botanical Origin Honeys Produced by Sicilian Black Honeybees (Apis mellifera ssp. sicula). J. Agric. Food Chem. 2015, 63, 5864-5874. [CrossRef]

71. Deng, J.; Liu, R.; Lu, Q.; Hao, P.; Xu, A.; Zhang, J.; Tan, J. Biochemical Properties, Antibacterial and Cellular Antioxidant Activities of Buckwheat Honey in Comparison to Manuka Honey. Food Chem. 2018, 252, 243-249. [CrossRef]

72. Kečkeš, S.; Gašić, U.; Veličković, T.Ć.; Milojković-Opsenica, D.; Natić, M.; Tešić, Ž. The Determination of Phenolic Profiles of Serbian Unifloral Honeys Using Ultra-High-Performance Liquid Chromatography/High Resolution Accurate Mass Spectrometry. Food Chem. 2013, 138, 32-40. [CrossRef] [PubMed]

73. Pyrzynska, K.; Biesaga, M. Analysis of Phenolic Acids and Flavonoids in Honey. Trac. Trends Anal. Chem. 2009, $28,893-902$. [CrossRef]

74. Zhao, J.; Du, X.; Cheng, N.; Chen, L.; Xue, X.; Wu, L.; Cao, W. Identification of Monofloral Honeys Using HPLC-ECD and Chemometrics. Food Chem. 2016, 194, 167-174. [CrossRef]

75. Cianciosi, D.; Forbes-Hernández, T.Y.; Afrin, S.; Gasparrini, M.; Reboredo-Rodriguez, P.; Manna, P.P.; Zhang, J.; Lamas, L.B.; Florez, S.M.; Toyos, P.A.; et al. Phenolic Compounds in Honey and Their Associated Health Benefits: A Review. Molecules 2018, 23, 2322. [CrossRef] [PubMed]

76. Pichichero, E.; Canuti, L.; Canini, A. Characterisation of the Phenolic and Flavonoid Fractions and Antioxidant Power of Italian Honeys of Different Botanical Origin. J. Sci. Food Agric. 2009, 89, 609-616. [CrossRef]

77. Sun, C.; Tan, H.; Zhang, Y.; Zhang, H. Phenolics and Abscisic Acid Identified in Acacia Honey Comparing Different SPE Cartridges Coupled with HPLC-PDA. J. Food Compos. Anal. 2016, 53, 91-101. [CrossRef]

78. Campillo, N.; Viñas, P.; Férez-Melgarejo, G.; Hernández-Córdoba, M. Dispersive Liquid-Liquid Microextraction for the Determination of Flavonoid Aglycone Compounds in Honey Using Liquid Chromatography with Diode Array Detection and Time-of-Flight Mass Spectrometry. Talanta 2015, 131, 185-191. [CrossRef] [PubMed]

79. Habib, H.M.; Al Meqbali, F.T.; Kamal, H.; Souka, U.D.; Ibrahim, W.H. Bioactive Components, Antioxidant and DNA Damage Inhibitory Activities of Honeys from Arid Regions. Food Chem. 2014, 153, 28-34. [CrossRef]

80. Campone, L.; Piccinelli, A.L.; Pagano, I.; Carabetta, S.; Di Sanzo, R.; Russo, M.; Rastrelli, L. Determination of Phenolic Compounds in Honey Using Dispersive Liquid-Liquid Microextraction. J. Chromatogr. A 2014, 1334, 9-15. [CrossRef]

81. Petrus, K.; Schwartz, H.; Sontag, G. Analysis of Flavonoids in Honey by HPLC Coupled with Coulometric Electrode Array Detection and Electrospray Ionization Mass Spectrometry. Anal. Bioanal. Chem. 2011, 400, 2555-2563. [CrossRef]

82. Liang, Y.; Cao, W.; Chen, W.J.; Xiao, X.H.; Zheng, J.B. Simultaneous determination of four phenolic components in citrus honey by high performance liquid chromatography using electrochemical detection. Food Chem. 2009, 114, 1537-1541. [CrossRef]

83. Wabaidur, S.M.; Ahmed, Y.B.H.; Alothman, Z.A.; Obbed, M.S.; AL-Harbi, N.M.; AL-Turki, T.M. Ultra High Performance Liquid Chromatography with Mass Spectrometry Method for the Simultaneous Determination of Phenolic Constituents in Honey from Various Floral Sources Using Multiwalled Carbon Nanotubes as Extraction Sorbents. J. Sep. Sci. 2015, 38, 2597-2606. [CrossRef] [PubMed]

84. Zhang, X.H.; Wu, H.L.; Wang, J.Y.; Tu, D.Z.; Kang, C.; Zhao, J.; Chen, Y.; Miu, X.X.; Yu, R.Q. Fast HPLC-DAD Quantification of Nine Polyphenols in Honey by Using Second-Order Calibration Method Based on Trilinear Decomposition Algorithm. Food Chem. 2013, 138, 62-69. [CrossRef] [PubMed]

85. Kuś, P.M.; Congiu, F.; Teper, D.; Sroka, Z.; Jerković, I.; Tuberoso, C.I.G. Antioxidant Activity, Color Characteristics, Total Phenol Content and General HPLC Fingerprints of Six Polish Unifloral Honey Types. LWT Food Sci. Technol. 2014, 55, 124-130. [CrossRef]

86. Kuś, P.M.; Jerković, I.; Tuberoso, C.I.G.; Marijanović, Z.; Congiu, F. Cornflower (Centaurea cyanus L.) Honey Quality Parameters: Chromatographic Fingerprints, Chemical Biomarkers, Antioxidant Capacity and Others. Food Chem. 2014, 142, 12-18. [CrossRef]

87. Dimitrova, B.; Gevrenova, R.; Anklam, E. Analysis of Phenolic Acids in Honeys of Different Floral Origin by Solid-Pase Extraction and High-Performance Liquid Chromatography. Phytochem. Anal. 2007, 18, 24-32. [CrossRef] [PubMed]

88. Bobiș, O.; Mărghitaş, L.; Bonta, V.; Dezmirean, D.; Maghear, O. Free Phenolic Acids, Flavonoids and Abscisic Acid Related to HPLC Sugar Profile in Acacia Honey. Bul. USAMV CN 2007, 64, 179-185.

89. Stephens, J.M.; Schlothauer, R.C.; Morris, B.D.; Yang, D.; Fearnley, L.; Greenwood, D.R.; Loomes, K.M. Phenolic Compounds and Methylglyoxal in Some New Zealand Manuka and Kanuka Honeys. Food Chem. 2010, 120, 78-86. [CrossRef]

90. Badjah Hadj Ahmed, A.Y.; Obbed, M.S.; Wabaidur, S.M.; AlOthman, Z.A.; Al-Shaalan, N.H. High-Performance Liquid Chromatography Analysis of Phenolic Acid, Flavonoid, and Phenol Contents in Various Natural Yemeni Honeys Using Multi-Walled Carbon Nanotubes as a Solid-Phase Extraction Adsorbent. J. Agric. Food Chem. 2014, 62, 5443-5450. [CrossRef]

91. Oelschlaegel, S.; Pieper, L.; Staufenbiel, R.; Gruner, M.; Zeippert, L.; Pieper, B.; Koelling-Speer, I.; Speer, K. Floral markers of cornflower (Centaurea cyanus) honey and its peroxide antibacterial activity for an alternative treatment of digital dermatitis. J. Agric. Food Chem. 2012, 60, 11811-11820. [CrossRef]

92. Jerković, I.; Tuberoso, C.; Kuś, P.M.; Marijanović, Z.; Kranjac, M. Screening of Coffea spp. honey by different methodologies: Theobromine and caffeine as chemical markers. RSC Adv. 2014, 4, 60557-60562. [CrossRef]

93. Jerković, I.; Kuś, P.M.; Tuberoso, C.I.G.; Šarolić, M. Phytochemical and Physical-Chemical Analysis of Polish Willow (Salix spp.) Honey: Identification of the Marker Compounds. Food Chem. 2014, 145, 8-14. [CrossRef]

94. Gambacorta, E.; Simonetti, A.; Garrisi, N.; Intaglietta, I.; Perna, A. Antioxidant Properties and Phenolic Content of Sulla (H edysarum spp.) Honeys from Southern Italy. Int. J. Food Sci. Technol. 2014, 49, 2260-2268. [CrossRef] 
95. Weston, R.J.; Mitchell, K.R.; Allen, K.L. Antibacterial Phenolic Components of New Zealand Manuka Honey. Food Chem. 1999, 64, 295-301. [CrossRef]

96. Chan, C.W.; Deadman, B.J.; Manley-Harris, M.; Wilkins, A.L.; Alber, D.G.; Harry, E. Analysis of the Flavonoid Component of Bioactive New Zealand Mānuka (Leptospermum scoparium) Honey and the Isolation, Characterisation and Synthesis of an Unusual Pyrrole. Food Chem. 2013, 141, 1772-1781. [CrossRef]

97. Venugopal, S.; Devarajan, S. Estimation of Total Flavonoids, Phenols and Antioxidant Activity of Local and New Zealand Manuka Honey. J. Pharm. Res. 2011, 4, 464-466.

98. Czipa, N. Különböző Eredetû́ Mézek Összehasonlító Vizsgálata És A Gyártmánykialakítás Hatása A Minőségre. [Comparative Study of Honeys with Different Origin, the Effect of Production-Forming on the Quality. Ph.D. Thesis, University of Debrecen, Debrecen, Hungary, 2010.

99. National Hungarian Beekeeping Association. Mézvizsgálat II. Méhészújság 2020, 7, 20-23.

100. Aazza, S.; Lyoussi, B.; Antunes, D.; Miguel, M.G. Physicochemical Characterization and Antioxidant Activity of Commercial Portuguese Honeys. J. Food Sci. 2013, 78, C1159-C1165. [CrossRef]

101. Zhelyazkova, I.; Lazarov, S. Comparative Study of Rapeseed, Monofloral Types and Multifloral Honey by Some Physicochemical Parameters. Agric. Sci. Technol. 2017, 9, 277-281. [CrossRef]

102. Gomes, S.; Dias, L.G.; Moreira, L.L.; Rodrigues, P.; Estevinho, L. Physicochemical, Microbiological and Antimicrobial Properties of Commercial Honeys from Portugal. Food Chem. Toxicol. 2010, 48, 544-548. [CrossRef] [PubMed]

103. Balkanska, R.; Ignatova, M. Physicochemical Parameters of Bulgarian Rape Honey (Brassica Sp.) and Coriander Honey (Coriandrum sativum L.). In Proceedings of the 10th International Symposium Modern Trends in Livestock Production, Belgrade, Serbia, 2-4 October 2013; pp. 618-626.

104. Pires, J.; Estevinho, M.L.; Feás, X.; Cantalapiedra, J.; Iglesias, A. Pollen Spectrum and Physico-Chemical Attributes of Heather (Erica sp.) Honeys of North Portugal. J. Sci. Food Agric. 2009, 89, 1862-1870. [CrossRef]

105. Anjos, O.; Iglesias, C.; Peres, F.; Martínez, J.; García, Á.; Taboada, J. Neural Networks Applied to Discriminate Botanical Origin of Honeys. Food Chem. 2015, 175, 128-136. [CrossRef]

106. Pauliuc, D.; Oroian, M. Organic Acids and Physico-Chemical Parameters of Romanian Sunflower Honey. Food Environ. Saf. J. 2020, 19, 148-155.

107. Eremia, N.; Neicovcena, I.; Grițunic, I. Physical and Chemical Indicators, Content of Micro and Macroelements and Heavy Metals in Sunflower Honey. Sci. Pap. Anim. Sci. Ser. 2019, 71, 105-108.

108. Chua, L.S.; Adnan, N.A. Biochemical and Nutritional Components of Selected Honey Samples. Acta Sci. Pol. Technol. Aliment. 2014, 13, 169-179. [CrossRef]

109. Wanjai, C.; Sringarm, K.; Santasup, C.; Pak-Uthai, S.; Chantawannakul, P. Physicochemical and Microbiological Properties of Longan, Bitter Bush, Sunflower and Litchi Honeys Produced by Apis mellifera in Northern Thailand. J. Apic. Res. 2012, 51, 36-44. [CrossRef]

110. Alpat, U. Comparison of Functional and Bioactive Properties of Pine Honey with Other Important Honeys Produced in Our Country. Ph.D. Thesis, Ylldız Technical University, İstanbul, Turkey, 2018.

111. Çinar, S.B.; Ekşi, A.; Coşkun, İ. Carbon Isotope Ratio (13C/12C) of Pine Honey and Detection of HFCS Adulteration. Food Chem. 2014, 157, 10-13. [CrossRef]

112. Özkök, A. Muğla Bölgesinde Üretilen Çam Balı ve Propolisin Mikroskobik, Organoleptik ve Kimyasal Analizi. Ph.D. Thesis, Hacettepe Üniversitesi, Ankara, Turkey, 2009.

113. Tolon, B. Muğla ve Yöresi Çam Ballarının Biyokimyasal Özellikleri Üzerine Bir Araştırma. Ph.D Thesis, Ege Üniversitesi Fen Bilimleri Enstitüsü Doktora Tezi İzmir, Bornova, İzmir, 1999.

114. Tsiapara, A.V.; Jaakkola, M.; Chinou, I.; Graikou, K.; Tolonen, T.; Virtanen, V. Bioactivity of Greek Honey Extracts on Breast Cancer (MCF-7), Prostate Cancer (PC-3) and Endometrial Cancer (Ishikawa) Cells: Profile Analysis of Extracts. Food Chem. 2009, 116, 702-708. [CrossRef]

115. Dinkov, D.H. Quality Parameters of Bulgarian Kinds of Bee Honey. Maced. Vet. Rev. 2014, 37, 35-41. [CrossRef]

116. Akgün, N. Ordu İlinde Üretilen Kestane Bal, Akasya Bal, Orman Gülü Balı ve Yayla Ballarının Fiziksel ve Kimyasal Aktiviteleri ile Antioksidan Özelliklerinin İncelenmesi; Yüksek Lisans; Fen Bilimleri Enstitüsü, Ordu Üniversitesi: Ordu, Turkey, 2017.

117. Bobiş, O.; Mărghitaş, L.A.; Dezmirean, D.; Bonta, V.; Mihai, C.M. Beehive Products: Source of Nutrients and Natural Biologically Active Compounds. J. Agroalim. Proc. Technol. 2010, 16, 104-109.

118. Zerrouk, S.; Seijo, M.C.; Escuredo, O.; Rodríguez-Flores, M.S. Characterization Of Ziziphus Lotus (Jujube) Honey Produced in Algeria. J. Apic. Res. 2017, 57, 166-174. [CrossRef]

119. Park, S.H.; Kim, Y.K.; Kim, M.S.; Lee, S.H. Antioxidant and Antibacterial Properties of Hovenia (Hovenia Dulcis) Monofloral Honey Produced in South Korea. Food Sci. Anim. Resour. 2020, 40, 221-230. [CrossRef]

120. Maieves, H.A.; Züge, L.C.B.; Teixeira, G.L.; Cámara, M.; Ribani, R.H.; Sánchez-Mata, M.C. Chemical Properties, Rheological Behavior, and Melissopalynological Analysis of Selected Brazilian Honeys from Hovenia dulcis Flowering. Braz. Arch. Biol. Technol. 2020, 63. [CrossRef]

121. EU. Council Directive 2001/110/CE Concerning Honey. Off. J. Eur. Communities 2002, L10, 47-52.

122. Codex Alimentarius Commission Standards. Revised Codex Standards for Honey; Codex Standard 12-1981, Rev. 2; Joint FAO/WHO Food Standards Programme. 24th Session; FAO Headquarters: Rome, Italy, 2001. 
123. Acquarone, C.; Buera, P.; Elizalde, B. Pattern of $\mathrm{pH}$ and Electrical Conductivity Upon Honey Dilution as a Complementary Tool for Discriminating Geographical Origin of Honeys. Food Chem. 2007, 101, 695-703. [CrossRef]

124. Manzanares, A.B.; García, Z.H.; Galdón, B.R.; Rodríguez, E.R.; Romero, C.D. Physicochemical characteristics of minor monofloral honeys from Tenerife, Spain. LWT Food Sci. Technol. 2014, 55, 572-578. [CrossRef]

125. Kabbani, D.; Sepulcre, F.; Wedekind, J. Ultrasound-Assisted Liquefaction of Rosemary Honey: Influence on Rheology and Crystal Content. J. Food Eng. 2011, 107, 173-178. [CrossRef]

126. Önür, I.; Misra, N.N.; Barba, F.J.; Putnik, P.; Lorenzo, J.M.; Gökmen, V.; Alpas, H. Effects of Ultrasound and High Pressure on Physicochemical Properties and HMF Formation in Turkish Honey Types. J. Food Eng. 2018, 219, 129-136. [CrossRef]

127. Bartáková, K.; Dračková, M.; Borkovcová, I.; Vorlová, L. Impact of Microwave Heating on Hydroxymethylfurfural Content in Czech Honeys. Czech J. Food Sci. 2011, 29, 328-336. [CrossRef]

128. Boateng, J.; Diunase, K.N. Comparing the Antibacterial and Functional Properties of Cameroonian and Manuka Honeys for Potential Wound Healing-Have We Come Full Cycle in Dealing with Antibiotic Resistance? Molecules 2015, 20 , 16068-16084. [CrossRef]

129. Johnston, M.; McBride, M.; Dahiya, D.; Owusu-Apenten, R.; Nigam, P.S. Antibacterial Activity of Manuka Honey and its Components: An Overview. AIMS Microbiol. 2018, 4, 655-664. [CrossRef]

130. Moniruzzaman, M.; Khalil, M.I.; Sulaiman, S.A.; Gan, S.H. Physicochemical and Antioxidant Properties of Malaysian Honeys Produced by Apis cerana, Apis dorsata and Apis mellifera. BMC Complement. Altern. Med. 2013, 13, 43. [CrossRef]

131. Moniruzzaman, M.; Sulaiman, S.A.; Khalil, M.I.; Gan, S.H. Evaluation of Physicochemical and Antioxidant Properties of Sourwood and Other Malaysian Honeys: A Comparison with Manuka Honey. Chem. Cent. J. 2013, 7, 138. [CrossRef] [PubMed]

132. Beitlich, N.; Koelling-Speer, I.; Oelschlaegel, S.; Speer, K. Differentiation of Manuka Honey from Kanuka Honey and from Jelly Bush Honey Using HS-SPME-GC/MS and UHPLC-PDA-MS/MS. J. Agric. Food Chem. 2014, 62, 6435-6444. [CrossRef]

133. Gethin, G.T.; Cowman, S.; Conroy, R.M. The impact of Manuka Honey Dressings on the Surface pH of Chronic Wounds. Int. Wound J. 2008, 5, 185-194. [CrossRef]

134. Machado De-Melo, A.A.; Almeida-Muradian, L.B.D.; Sancho, M.T.; Pascual-Maté, A. Composition and Properties of Apis mellifera Honey: A Review. J. Apic. Res. 2018, 57, 5-37. [CrossRef]

135. De Almeida-Muradian, L.B. Tetragonisca Angustula Pot-Honey Compared to Apis mellifera Honey from Brazil. Pot Honey 2013, 375-382. [CrossRef]

136. Sabatini, A.G. Il Miele: Origine, Composizione E Proprieta; Sabatini, A.G., Botolotti, L., Marcazzan, G.L., Eds.; Conscere Il Miele; Avenue Media: Bologna, Italy; Milano, Italy, 2007; pp. 3-37.

137. International Honey Commission. Harmonised Methods of the International Honey Comm. 2009. Available online: http: / / www.bee-hexagon.net/en/network.htm. (accessed on 1 May 2021).

138. Doner, L.W. Honey. In Encyclopedia of Food Sciences and Nutrition, 2nd ed.; Caballero, B., Finglas, P.M., Trugo, L.C., Eds.; Academic Press: London, UK, 2003; pp. 3125-3130.

139. Alda-Garcilope, C.; Gallego-Pico, A.; Bravo-Yague, J.C.; Garcinuno-Martınez, R.M.; Fernandez-Hernando, P. Characterization of Spanish Honeys with Protected Designation of Origin “Miel de Granada" According to Their Mineral Content. Food Chem. 2012, 135, 1785-1788. [CrossRef] [PubMed]

140. Chen, H.; Fan, C.; Chang, Q.; Pang, G.; Hu, X.; Lu, M.; Wang, W. Chemometric Determination of the Botanical Origin for Chinese Honeys on the Basis of Mineral Elements Determined by ICP-MS. J. Agric. Food Chem. 2014, 62, 2443-2448. [CrossRef] [PubMed]

141. Fernández-Torres, R.; Perez-Bernal, J.L.; Bello-Lopez, M.A.; Callejon-Mochon, M.; Jimenez-Sanchez, J.C.; Guiraúm-Pérez, A. Mineral Content and Botanical Origin of Spanish Honeys. Talanta 2005, 65, 686-691. [CrossRef]

142. Karabagias, I.K.; Louppis, A.P.; Kontakos, S.; Papastephanou, C.; Kontominas, M.G. Characterization and Geographical Discrimination of Greek Pine and Thyme Honeys Based on Their Mineral Content, Using Chemometrics. Eur. Food Res. Technol. 2017, 243, 101-113. [CrossRef]

143. Louppis, A.P.; Karabagias, I.K.; Kontakos, S.; Kontominas, M.G.; Papastephanou, C. Botanical Discrimination of Greek Unifloral Honeys Based on Mineral Content in Combination with Physicochemical Parameter Analysis, Using a Validated Chemometric Approach. Microchem. J. 2017, 135, 180-189. [CrossRef]

144. Moniruzzaman, M.; Chowdhury, M.A.Z.; Rahman, M.A.; Sulaiman, S.A.; Gan, S.H. Determination of Mineral, Trace Element, and Pesticide Levels in Honey Samples Originating from Different Regions of Malaysia Compared to Manuka Honey. BioMed Res. Int. 2014, 2014, 359890. [CrossRef]

145. Tudoreanu, L.; Codreanu, M.D.; Crivineanu, V.; Goran, G.V. The Quality of Romanian Honey Varieties-Mineral Content and Textural Properties. Bull. Univ. Agric. Sci. Vet. Med. Cluj Napoca Vet. Med. 2012, 69, 1-2.

146. Atanassova, J.; Yurukova, L.; Lazarova, M. Pollen and inorganic characteristics of Bulgarian unifloral honeys. Czech J. Food Sci. 2012, 30, 520-526. [CrossRef]

147. Nalda, M.N.; Yagüe, J.B.; Calva, J.D.; Gómez, M.M. Classifying Honeys from the Soria Province of Spain Via Multivariate Analysis. Anal. Bioanal. Chem. 2005, 382, 311-319. [CrossRef]

148. Di Bella, G.; Turco, V.L.; Potorti, A.G.; Bua, G.D.; Fede, M.R.; Dugo, G. Geographical Discrimination of Italian Honey by Multi-Element Analysis with a Chemometric Approach. J. Food Compos. Anal. 2015, 44, 25-35. [CrossRef]

149. Atanassova, J.; Yurukova, L.; Lazarova, M. Palynological, Physical, and Chemical Data on Honey from the Kazanlak Region (Central Bulgaria). Phytol. Balc. 2009, 15, 107-114. 
150. Marghitas, L.A.; Dezmirean, D.S.; Pocol, C.B.; Marioara, I.L.E.A.; Bobis, O.; Gergen, I. The Development of a Biochemical Profile of Acacia Honey by Identifying Biochemical Determinants of its Quality. Not. Bot. Horti Agrobot. Cluj Napoca 2010, 38, 84-90.

151. Popa, M.; Bostan, R.; Popa, D. Honey-Marker of Environmental Pollution. Case study—The Transylvania Region, Romania. J. Environ. Prot. Ecol. 2013, 14, 273-280.

152. Imtara, H.; Elamine, Y.; Lyoussi, B. Physicochemical Characterization and Antioxidant Activity of Palestinian Honey Samples. Food Sci. Nutr. 2018, 6, 2056-2065. [CrossRef]

153. Solayman, M.; Islam, M.A.; Paul, S.; Ali, Y.; Khalil, M.I.; Alam, N.; Gan, S.H. Physicochemical Properties, Minerals, Trace Elements, and Heavy Metals in Honey of Different Origins: A Comprehensive Review. Compr. Rev. Food Sci. Food Saf. 2015, 15, 219-233. [CrossRef]

154. Meda, A.; Lamien, C.E.; Romito, M.; Millogo, J.; Nacoulma, O.G. Determination of the Total Phenolic, Flavonoid and Proline Contents in Burkina Fasan Honey, as well as Their Radical Scavenging Activity. Food Chem. 2005, 91, 571-577. [CrossRef]

155. Aliyu, M.; Odunola, O.A.; Farooq, A.D.; Mesaik, A.M.; Choudhary, M.I.; Fatima, B.; Qureshi, T.A.; Erukainure, O.L. Acacia Honey Modulates Cell Cycle Progression, Pro-Inflammatory Cytokines and Calcium Ions Secretion in PC-3 Cell Line. Cancer Sci. Ther. 2012, 4, 401-407. [CrossRef]

156. Aliyu, M.; Ibrahim, S.; Inuwa, H.M.; Sallau, A.B.; Abbas, O.; Aimola, I.A.; Habila, N.; Uche, N.S. Ameliorative Effects of Acacia Honey Against Sodium Arsenite-Induced Oxidative Stress in Some Viscera of Male Wistar Albino Rats. Biochem. Res. Int. 2013, 2013, 502438. [CrossRef]

157. Salleh, M.A.M.; Eshak, Z.; Ismail, W.I.W. Acacia Honey Induces Apoptosis in Human Breast Adenocarcinoma Cell Lines (MCF-7). J. Teknologi. 2017, 79. [CrossRef]

158. Sadeghi-Aliabadi, H.; Hamzeh, J.; Mirian, M. Investigation of Astragalus honey and propolis extract's cytotoxic effect on two human cancer cell lines and their oncogen and proapoptotic gene expression profiles. Adv. Biomed. Res. 2015, 4, 42. [CrossRef]

159. Anand, S.; Pang, E.; Livanos, G.; Mantri, N. Characterization of Physico-Chemical Properties and Antioxidant Capacities of Bioactive Honey Produced from Australian Grown Agastache Rugosa and its Correlation with Colour and Poly-Phenol Content. Molecules 2018, 23, 108. [CrossRef]

160. Eteraf-Oskouei, T.; Najafi, M. Traditional and Modern Uses of Natural Honey in Human Diseases: A Review. Iran. J. Basic Med. Sci. 2013, 16, 731-742. [PubMed]

161. Pichichero, E.; Cicconi, R.; Mattei, M.; Muzi, M.G.; Canini, A. Acacia Honey and Chrysin Reduce Proliferation of Melanoma Cells Through Alterations in Cell Cycle Progression. Int. J. Oncol. 2010, 37, 973-981. [PubMed]

162. Van den Berg, A.J.J.; Van den Worm, E.; Quarles van Ufford, H.C.; Halkes, S.B.A.; Hoekstra, M.J.; Beukelman, C.J. An In Vitro Examination of the Antioxidant and Anti-Inflammatory Properties of Buckwheat Honey. J. Wound Care 2008, 17, 172-178. [CrossRef]

163. García-Tenesaca, M.; Navarrete, E.S.; Iturralde, G.A.; Villacrés Granda, I.M.; Tejera, E.; Beltrán-Ayala, P.; Giampieri, F.; Battino, M.; Alvarez-Suarez, J.M. Influence of Botanical Origin and Chemical Composition on the Protective Effect Against Oxidative Damage and the Capacity to Reduce in Vitro Bacterial Biofilms of Monofloral Honeys from the Andean Region of Ecuador. Int. J. Mol. Sci. 2018, 19, 45. [CrossRef]

164. Dobre, I.; Escuredo, O.; Rodriguez-Flores, S.; Seijo, M.C. Evaluation of Several Romanian Honeys Based on Their Palynological and Biochemical Profiles. Int. J. Food Prop. 2014, 17, 1850-1860. [CrossRef]

165. Sipahi, H.; Aydoğan, G.; Helvacioğlu, S.; Charehsaz, M.; Guzelmeric, E.; Aydin, A. Antioxidant, Antiinflammatory and Antimutagenic Activities of Various Kinds of Turkish Honey. FABAD J. Pharm. Sci. 2017, 42, 7-13.

166. Seyhan, M.F.; Yılmaz, E.; Timirci-Kahraman, Ö.; Saygıll, N.; Kısakesen, H.İ.; Eronat, A.P.; Ceviz, A.B.; Gazioğlu, S.B.; Aydoğan, H.Y.; Öztürk, O. Anatolian Honey is not only Sweet But Can Also Protect from Breast Cancer: Elixir for Women from Artemis to Present. IUBMB Life 2017, 69, 677-688. [CrossRef] [PubMed]

167. Kolayli, S.; Sahin, H.; Can, Z.; Yildiz, O.; Sahin, K. Honey Shows Potent Inhibitory Activity Against the Bovine Testes Hyaluronidase. J. Enzym. Inhib. Med. Chem. 2016, 31, 599-602. [CrossRef]

168. Badria, F.; Fathy, H.; Fatehe, A.; Elimam, D.; Ghazy, M. Evaluate the Cytotoxic Activity of Honey, Propolis, and Bee Venom from Different Localities in Egypt Against Liver, Breast, and Colorectal Cancer. J Apither. 2017, 2, 1-4. [CrossRef]

169. Ciappini, M.C.; Stoppani, F.S. Determination of Antioxidant Capacity, Flavonoids, and Total Phenolic Content in Eucalyptus and Clover Honeys. J. Apic. Sci. 2014, 58, 103-111. [CrossRef]

170. Jerković, I.; Radonić, A.; Kranjac, M.; Zekić, M.; Marijanović, Z.; Gudićc, S.; Kliškić, M. Red clover (Trifolium pratense L.) Honey: Volatiles Chemical-Profiling and Unlocking Antioxidant and Anticorrosion Capacity. Chem. Pap. 2016, 70, 726-736. [CrossRef]

171. Akbari, E.; Baigbabaei, A.; Shahidi, M. Determination of the Floral Origin of Honey Based on its Phenolic Profile and Physicochemical Properties Coupled with Chemometrics. Int. J. Food Prop. 2020, 23, 506-519. [CrossRef]

172. Kivrak, Ş.; Kivrak, İ. Assessment of Phenolic Profile of Turkish Honeys. Int. J. Food Prop. 2017, 20, 864-876. [CrossRef]

173. Aumeeruddy, M.Z.; Aumeeruddy-Elalfi, Z.; Neetoo, H.; Zengin, G.; van Staden, A.B.; Fibrich, B.; Lambrechts, I.A.; Rademan, S.; Szuman, K.M.; Lall, N.; et al. Pharmacological Activities, Chemical Profile, and Physicochemical Properties of Raw and Commercial Honey. Biocatal. Agric. Biotechnol. 2019, 18, 101005. [CrossRef]

174. Jasicka-Misiak, I.; Makowicz, E.; Stanek, N. Chromatographic Fingerprint, Antioxidant Activity, and Colour Characteristic of Polish Goldenrod (Solidago virgaurea L.) Honey and Flower. Eur. Food Res. Technol. 2018, 244, 1169-1184. [CrossRef] 
175. Shen, S.; Wang, J.; Chen, X.; Liu, T.; Zhuo, Q.; Zhang, S.Q. Evaluation of Cellular Antioxidant Components of Honeys Using UPLC-MS/MS and HPLC-FLD Based on the Quantitative Composition-Activity Relationship. Food Chem. 2019, 293, 169-177. [CrossRef] [PubMed]

176. Kishore, R.K.; Halim, A.S.; Syazana, M.N.; Sirajudeen, K.N.S. Tualang Honey has Higher Phenolic Content and Greater Radical Scavenging Activity Compared with Other Honey Sources. Nutr. Res. 2011, 31, 322-325. [CrossRef]

177. Batumalaie, K.; Qvist, R.; Yusof, K.M.; Ismail, I.S.; Sekaran, S.D. The Antioxidant Effect of the Malaysian Gelam Honey on Pancreatic Hamster Cells Cultured Under Hyperglycemic Conditions. Clin. Exp. Med. 2014, 14, 185-195. [CrossRef]

178. Morales, P.; Haza, A.I. Antiproliferative and Apoptotic Effects of Spanish Honeys. Pharmacogn. Mag. 2013, 9, 231-237. [PubMed]

179. Haza, A.I.; Morales, P. Spanish Honeys Protect Against Food Mutagen-Induced DNA Damage. J. Sci. Food Agric. 2013, 93, 2995-3000. [CrossRef]

180. Bertoncelj, J.; Doberšek, U.; Jamnik, M.; Golob, T. Evaluation of the Phenolic Content, Antioxidant Activity and Colour of Slovenian Honey. Food Chem. 2007, 105, 822-828. [CrossRef]

181. Sharma, R.; Martins, N.; Chaudhary, A.; Garg, N.; Sharma, V.; Kuca, K.; Nepovimova, E.; Tuli, H.S.; Bishayee, A.; Chaudhary, A.; et al. Adjunct Use of Honey in Diabetes Mellitus: A Consensus or Conundrum? Trends Food Sci. Technol. 2020, 106, 254-274. [CrossRef]

182. Fernandez-Cabezudo, M.J.; El-Kharrag, R.; Torab, F.; Bashir, G.; George, J.A.; El-Taji, H.; Al-Ramadi, B.K. Intravenous Administration of Manuka Honey Inhibits Tumor Growth and Improves Host Survival When Used in Combination with Chemotherapy in a Melanoma Mouse Model. PLoS ONE 2013, 8, e55993. [CrossRef]

183. Kocyigit, A.; Aydogdu, G.; Balkan, E.; Yenigun, V.B.; Guler, E.M.; Bulut, H.; Koktasoğlu, F.; Gören, A.C.; Atayoglu, A.T. Quercus Pyrenaica Honeydew Honey with High Phenolic Contents Cause DNA Damage, Apoptosis, and Cell Death Through Generation of Reactive Oxygen Species in Gastric Adenocarcinoma Cells. Integr. Cancer Ther. 2019, 18, 1534735419876334. [CrossRef]

184. Samat, S.; Salleh, M.A.M.; Adam, Z.; Ismail, W.W. Pineapple Honey Inhibits Adipocytes Proliferation and Reduces Lipid Droplet Accumulation in 3T3-L1 Adipocytes. Malays. Appl. Biol. 2019, 48, 21-26.

185. Combarros-Fuertes, P.; Estevinho, L.M.; Dias, L.G.; Castro, J.M.; Tomás-Barberán, F.A.; Tornadijo, M.E.; Fresno-Baro, J.M. Bioactive Components and Antioxidant and Antibacterial Activities of Different Varieties of Honey: A Screening Prior to Clinical Application. J. Agric. Food Chem. 2018, 67, 688-698. [CrossRef]

186. Staver, M.M.; Ratkaj, I.; Broznić, D.; Jerković, I.; Marijanović, Z.; Željezić, D.; Pavelić, S.K. Bioactivity of Satureja Montana L. Honey Extracts and Their Profile Screening. RSC Adv. 2014, 4, 47329-47340. [CrossRef]

187. Afrin, S.; Forbes-Hernandez, T.Y.; Gasparrini, M.; Bompadre, S.; Quiles, J.L.; Sanna, G.; Spano, N.; Giampieri, F.; Battino, M. Strawberry-tree honey induces growth inhibition of human colon cancer cells and increases ROS generation: A comparison with Manuka honey. Int. J. Mol. Sci. 2017, 18, 613. [CrossRef] [PubMed]

188. Afrin, S.; Forbes-Hernández, T.Y.; Cianciosi, D.; Pistollato, F.; Zhang, J.; Pacetti, M.; Amici, A.; Reboredo-Rodriguez, P.; Simal-Gandara, J.; Bompadre, S.; et al. Strawberry Tree Honey as a New Potential Functional Food. Part 2: Strawberry Tree Honey Increases ROS Generation by Suppressing Nrf2-ARE and NF- $\kappa B$ Signaling Pathways and Decreases Metabolic Phenotypes and Metastatic Activity in Colon Cancer Cells. J. Funct. Foods 2019, 57, 477-487. [CrossRef]

189. Ulloa, P.A.; Maia, M.; Brigas, A.F. Physicochemical Parameters and Bioactive Compounds of Strawberry Tree (Arbutus unedo L.) Honey. J. Chem. 2015, 2015, 602792. [CrossRef]

190. Erejuwa, O.O.; Sulaiman, S.A.; Wahab, M.S.; Sirajudeen, K.N.S.; Salleh, M.M.; Gurtu, S. Antioxidant Protection of Malaysian Tualang Honey in Pancreas of Normal and Streptozotocin-Induced Diabetic Rats. Ann. D Endocrinol. 2010, 71, 291-296. [CrossRef]

191. Fauzi, A.N.; Norazmi, M.N.; Yaacob, N.S. Tualang Honey Induces Apoptosis and Disrupts the Mitochondrial Membrane Potential of Human Breast and Cervical Cancer Cell Lines. Food Chem. Toxicol. 2011, 49, 871-878. [CrossRef] [PubMed]

192. Ghashm, A.A.; Othman, N.H.; Khattak, M.N.; Ismail, N.M.; Saini, R. Antiproliferative Effect of Tualang Honey on Oral Squamous Cell Carcinoma and Osteosarcoma Cell Lines. BMC Complement. Altern. Med. 2010, 10, 49. [CrossRef]

193. Idris, Y.M.A.; Mariod, A.A.; Hamad, S.I. Physicochemical Properties, Phenolic Contents and Antioxidant Activity of Sudanese Honey. Int. J. Food Prop. 2011, 14, 450-458. [CrossRef]

194. Suleiman, M.H.; ALaerjani, W.M.A.; Mohammed, M.E.A. Influence of Altitudinal Variation on the Total Phenolic and Flavonoid Content of Acacia and Ziziphus Honey. Int. J. Food Prop. 2020, 23, 2077-2086. [CrossRef]

195. Rosa, A.; Tuberoso, C.I.G.; Atzeri, A.; Melis, M.P.; Bifulco, E.; Dessì, M.A. Antioxidant Profile of Strawberry Tree Honey and its Marker Homogentisic Acid in Several Models of Oxidative Stress. Food Chem. 2011, 129, 1045-1053. [CrossRef]

196. Wang, X.; Yang, S.; He, J.; Chen, L.; Zhang, J.; Jin, Y.; Zhou, J.; Zhang, Y. A Green Triple-Locked Strategy Based on VolatileCompound Imaging, Chemometrics, and Markers to Discriminate Winter Honey and Sapium Honey Using Headspace Gas Chromatography-Ion Mobility Spectrometry. Food Res. Int. 2019, 119, 960-967. [CrossRef] [PubMed]

197. Socha, R.; Juszczak, L.; Pietrzyk, S.; Gałkowska, D.; Fortuna, T.; Witczak, T. Phenolic Profile and Antioxidant Properties of Polish Honeys. Int. J. Food Sci. Technol. 2011, 46, 528-534. [CrossRef]

198. Rodriguez, B.A.; Mendoza, S.; Iturriga, M.H.; Castaño-Tostado, E. Quality Parameters and Antioxidant and Antibacterial Properties of Some Mexican Honeys. J. Food Sci. 2012, 77, C121-C127. [CrossRef] [PubMed]

199. Alvarez-Suarez, J.M.; Gonzalez-Paramas, A.M.; Santos-Buelga, C.; Battino, M. Antioxidant Characterization of Native Monofloral Cuban Honeys. J. Agric. Food Chem. 2010, 58, 9817-9824. [CrossRef] [PubMed] 
200. Alvarez-Suarez, J.M.; Tulipani, S.; Díaz, D.; Estevez, Y.; Romandini, S.; Giampieri, F.; Damiani, E.; Astolfi, P.; Bompadre, S.; Battino, M. Antioxidant and Antimicrobial Capacity of Several Monofloral Cuban Honeys and Their Correlation with Color, Polyphenol Content and Other Chemical Compounds. Food Chem. Toxicol. 2010, 48, 2490-2499. [CrossRef]

201. Demirhan, A. Balın Halk Tedavilerindeki Yeri ve Modern Tıp Açısından Önemi. Dirim 1981, 96, 364-367.

202. Üçer, M. İbni Sina'nın Kanun fi't-tıbb'ında Bal ve Kına ile Yapılan Ilaçlar Üzerine Etkileri; Bildiriler Kitapçı̆̆ı, Uluslararası İbni Sina Sempozyumu: Ankara, Turkey, 1984; pp. 323-331.

203. Yücel, B.; Akçiçek, E. Balın Modern Tıpta Kullanımı. Hasad Gıda 2005, 244, 22-25.

204. Šedík, P.; Horská, E.; Adam, Š.; Miškeje, M. Mineral Content as an Aspect of Nutrition Marketing: Case Study of Honey Market in Slovakia. J. Food Nutr. Res. 2020, 59, 185-192.

205. Omotayo, E.O.; Gurtu, S.; Sulaiman, S.A.; Wahab, M.S.A.; Sirajudeen, K.N.S.; Salleh, M.S.M. Hypoglycemic and Antioxidant Effects of Honey Supplementation in Streptozotocin-Induced Diabetic Rats. Int. J. Vitam. Nutr. Res. 2010, 80, 74-82. [CrossRef]

206. Erejuwa, O.O.; Sulaiman, S.A.; Wahab, M.S.A.; Sirajudeen, K.N.S.; Salleh, S.M.; Gurtu, S. Antioxidant Protective Effect of Glibenclamide and Metformin in Combination with Honey in Pancreas of Streptozotocin-Induced Diabetic Rats. Int. J. Mol. Sci. 2010, 11, 2056-2066. [CrossRef]

207. Kadir, E.A.; Sulaiman, S.A.; Yahya, N.K.; Othman, N.H. Inhibitory Effects of Tualang Honey on Experimental Breast Cancer in Rats: A Preliminary Study. Asian Pac. J. Cancer Prev. 2013, 14, 2249-2254. [CrossRef]

208. Sibel, S.; Enis, Y.M.; Hüseyin, S.; Timucin, A.A.; Duran, O. Analysis of Grayanatoxin in Rhododendron Honey and Effect on Antioxidant Parameters in Rats. J. Ethnopharmacol. 2014, 156, 155-161. [CrossRef]

209. Eraslan, G.; Kanbur, M.; Silici, S.; Karabacak, M. Beneficial Effect of Pine Honey on Trichlorfon Induced Some Biochemical Alterations in Mice. Ecotoxicol. Environ. Saf. 2010, 73, 1084-1091. [CrossRef]

210. Bezerra, M.L.R.; De Souza, E.L.; de Sousa, J.M.B.; Lima, M.D.S.; Alves, A.F.; Almeida, M.D.G.; Alves, R.C.; de Araújo, E.V.; Soares, N.L.; Da Silva, G.A.; et al. Effects of Honey from Mimosa quadrivalvisl (malícia) Produced by the Melipona Subnitidad. (jandaíra) Stingless Bee on Dyslipidaemic Rats. Food Funct. 2018, 9, 4480-4492. [CrossRef] [PubMed]

211. Mooty, M.A.; Nisr, N.A.E.; Wahba, N.M.; Complement, I. Influence of Intravenous Egyptian Fennel Honey Infusion on the Antioxidant Activities and Some Haemo-Indices In Healthy Goats. Int. J. Complement. Altern. Med. 2018, 11, $281-286$.

212. Nasuti, C.; Gabbianelli, R.; Falcioni, G.; Cantalamessa, F. Antioxidative and Gastroprotective Activities of Anti-Inflammatory Formulations Derived from Chestnut Honey in Rats. Nutr. Res. 2006, 26, 130-137. [CrossRef]

213. Nemoseck, T.M.; Carmody, E.G.; Furchner-Evanson, A.; Gleason, M.; Li, A.; Potter, H.; Lauren, M.R.; Kelly, J.L.; Kern, M. Honey Promotes Lower Weight Gain, Adiposity, and Triglycerides Than Sucrose in Rats. Nutr. Res. 2011, 31, 55-60. [CrossRef]

214. Samat, S.; Kanyan Enchang, F.; Nor Hussein, F.; Wan Ismail, W.I. Four-Week Consumption of Malaysian Honey Reduces Excess Weight Gain and Improves Obesity-Related Parameters in High Fat Diet Induced Obese Rats. Evid. Based Complement. Altern. Med. 2017, 2017, 1342150. [CrossRef]

215. Chepulis, L.; Starkey, N. The Long-Term Effects of Feeding Honey Compared with Sucrose and a Sugar-Free Diet on Weight Gain, Lipid Profiles, and DEXA Measurements in Rats. J. Food Sci. 2007, 73, H1-H7. [CrossRef] [PubMed]

216. Khalil, M.; Tanvir, E.M.; Afroz, R.; Sulaiman, S.A.; Gan, S.H. Cardioprotective Effects of Tualang Honey: Amelioration of Cholesterol and Cardiac Enzymes Levels. BioMed Res. Int. 2015, 2015, 286051. [CrossRef]

217. Samat, S.; Enchang, F.K.; Abd Razak, A.; Hussein, F.N.; Ismail, W.I.W. Adulterated Honey Consumption Can Induce Obesity, Increase Blood Glucose Level and Demonstrate Toxicity Effects. Sains Malays. 2018, 47, 353-365.

218. Öztaşan, N.; Altinkaynak, K.; Akçay, F.; Göçer, F.; Dane, Ş. Effects of Mad Honey on Blood Glucose and Lipid Levels in Rats with Streptozocin-Induced Diabetes. Turk. J. Vet. Anim. Sci. 2005, 29, 1093-1096.

219. Abdulrhman, M.A. Honey as a sole treatment of type 2 diabetes mellitus. Endocrinol. Metab. Syndr. 2016, 5, 1000232. [CrossRef]

220. Whitfield, P.; Parry-Strong, A.; Walsh, E.; Weatherall, M.; Krebs, J.D. The Effect of a Cinnamon-, Chromium-and MagnesiumFormulated Honey on Glycaemic Control, Weight Loss and Lipid Parameters in Type 2 Diabetes: An Open-Label Cross-Over Randomised Controlled Trial. Eur. J. Nutr. 2016, 55, 1123-1131. [CrossRef] [PubMed]

221. Abdulrhman, M. Honey Therapy in a Patient Volunteer with Type 2 Diabetes Mellitus: Case Report. J. Clin. Trials 2013, 3, 2-10. [CrossRef]

222. Abdulrhman, M.M.; El-Hefnawy, M.H.; Aly, R.H.; Shatla, R.H.; Mamdouh, R.; Mahmoud, D.M.; Mohamed, W.S. Metabolic Effects of Honey in Type 1 Diabetes Mellitus: A Randomized Crossover Pilot Study. J. Med. Food. 2013, 16, 66-72. [CrossRef]

223. Hegazi, A.G.; Abdel-Rahman, E.H.; Abd-Allah, F.; Abdou, A.M. Influence of Honey on Immune Status in Mice-Bearing Ehrlich Carcinoma. J. Clin. Cell. Immunol. 2015, 6, 1000295.

224. Mohamed, Z.B.H.; Alfarisi, H.A.H.; Abdullah, N.Z.; Harun, N.; Muhammad, N.; Rahim, R.A. Renoprotective Role of Tualang Honey Against High Cholesterol Diet Induced Acute Kidney Diseases in an Animal Model. J. Appl. Pharm. Sci. 2017, 7, 97-101.

225. Cheng, N.; Wu, L.; Zheng, J.; Cao, W. Buckwheat Honey Attenuates Carbon Tetrachloride-Induced Liver and DNA Damage in Mice. Evid. Based Complement. Altern. Med. 2015, 2015, 987385. [CrossRef]

226. Mansouri-Tehrani, H.A.; Rabbani-Khorasgani, M.; Hosseini, S.M.; Mokarian, F.; Mahdavi, H.; Roayaei, M. Effect of Supplements: Probiotics and Probiotic Plus Honey on Blood Cell Counts and Serum IgA in Patients Receiving Pelvic Radiotherapy. J. Res. Med Sci. 2015, 20, 679-683.

227. Hermanns, R.; Mateescu, C.; Thrasyvoulou, A.; Tananaki, C.; Wagener, F.A.; Cremers, N.A. Defining the Standards for Medical Grade Honey. J. Apic. Res. 2020, 59, 125-135. [CrossRef] 
228. Scepankova, H.; Saraiva, J.A.; Estevinho, L.M. Honey Health Benefits and Uses in Medicine. Bee Prod. Chem. Biol. Prop. 2017, 83-96. [CrossRef]

229. Molan, P. Why Honey Effective as a Medicine? Its Use in Modern Medicine. Bee World 1999, 80, 80-92. [CrossRef]

230. Söğüt, Ö.; Sayhan, M.B.; Mordeniz, C.; Gökdemir, M.T.; Al, B. Deli Bal Zehirlenmesi: Olgu Sunumu Ve Literatürün Gözden Geçirilmesi. Anatol. J. Clin. Investig. 2009, 3, 100-102.

231. Stangaciu, S. Internet Apitherapy Course Notes. (Lesson 25: Honey Composition; Lesson: 46: Honey indications). Available online: http:/ / www.apitherapy.com (accessed on 28 January 2021).

232. Ramsay, E.I.; Rao, S.; Madathil, L.; Hegde, S.K.; Baliga-Rao, M.P.; George, T.; Baliga, M.S. Honey in Oral Health and Care: A Mini Review. J. Oral Biosci. 2019, 61, 32-36. [CrossRef] [PubMed]

233. Tang, J.S.; Compton, B.J.; Marshall, A.; Anderson, R.; Li, Y.; van der Woude, H.; Hermans, I.F.; Painter, F.G.; Gasser, O. Mānuka Honey-Derived Methylglyoxal Enhances Microbial Sensing by Mucosal-Associated Invariant T Cells. Food Func. 2020, 11, 5782-5787. [CrossRef] [PubMed]

234. Moghadam, M.N.; Khaledi, E.M. Antibacterial Activity and Mechanism of Action of Some Iranian Honeys Compared to Manuka Honey Against Multidrug-Resistant Respiratory and Urinary Infections. Food Biosci. 2021, 41, 101003. [CrossRef]

235. Majtan, J.; Majtan, V. Is Manuka Honey the Best Type of Honey for Wound Care? J. Hosp. Infect. 2010, 74, 305-306. [CrossRef] [PubMed]

236. Jaganathan, S.K.; Mandal, M. Antiproliferative Effects of Honey and of Its Polyphenols: A Review. J. Biomed. Biotechnol. 2009, 2009, 830616. [CrossRef]

237. Jaganathan, S.K. Growth Inhibition by Caffeic Acid, One of the Phenolic Constituents of Honey, in HCT 15 Colon Cancer Cells. Sci. World J. 2012, 2012, 372345. [CrossRef]

238. Swellam, T.; Miyanaga, N.; Onozawa, M.; Hattori, K.; Kawai, K.; Shimazui, T.; Akaza, H. Antineoplastic activity of honey in an experimental bladder cancer implantation model: In vivo and in vitro studies. Int. J. Urol. 2003, 10, 213-219. [CrossRef] [PubMed]

239. Aziz Baiomy, A.A.; Rady, H.M.; Amer, M.A.; Kiwan, H.S. Effect of Some Honey Bee Extracts on the Proliferation, Proteolytic and Gelatinolytic Activities of the Hepatocellular Carcinoma Hepg2 Cell Line. Aust. J. Basic Appl. Sci. 2009, 3, $2754-2769$.

240. Bogdanov, S. Honey as Nutrient and Functional Food. Honey; Bee Product Science: 2017; Chapter 8. Available online: www.bee-hexagon.net (accessed on 13 February 2021).

241. Jaganathan, S.K.; Balaji, A.; Vellayappan, M.V.; Asokan, M.K.; Subramanian, A.P.; John, A.A.; Supriyanto, E.; Razak, S.I.; Marvibaigi, M. A Review on Antiproliferative and Apoptotic Activities of Natural Honey. Anticancer Agents Med. Chem. 2015, 15, 48-56. [CrossRef] [PubMed]

242. Waheeda, M.; Hussain, M.B.; Javed, A.; Mushtaq, Z.; Hassan, S.; Shariati, M.A.; Khan, M.U.; Majeed, M.; Nigam, M.; Mishra, A.P.; et al. Honey and Cancer: A Mechanistic Review. Clin. Nutr. 2019, 38, 2499-2503. [CrossRef] [PubMed]

243. Kudva, A.K.; Rao, S.; Rao, P.; Pais, M.; Adnan, M.; Pai, K.S.; Baliga, M.S. Evidence for Anticancer Properties of Honey with Emphasis on Mechanistic Overview. Funct. Foods Cancer Prev. Ther. 2020, 121-135. [CrossRef] 